$$
\frac{661}{12.10^{\circ} \times c}
$$

$\$ 1$

$$
D r .2108
$$

$R 533$

LBL-10140

UC-66b

MASTER

GEOTHERMAL EXPLORATION ASSESSMENT AND INTERPRETATION UPPER KLAMATH LAKE AREA, KLAMATH BASIN, OREGON

Mitchel Stark, Norman E Goldstein and Harold A. Wollenberg

September 1980

Prepared for the U.S. Department of Energy under Contract W-7405-ENG-48

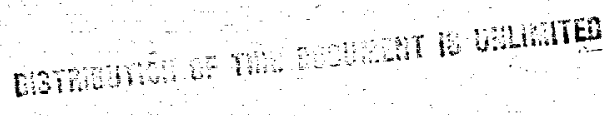




\title{
GEOTHERMAL EXPLORATION ASSESSMENT AND INTERPRETATION, UPPER KLAMATH LAKE AREA, KLAMATH BASIN, OREGON
}

\author{
by
}

Mitchel Stark, Norman E. Goldstein

and Harold A. Wollenberg

September 1980

Earth Sciences Division Lawrence Berkeley Laboratory

University of California

Berkeley, California 94720

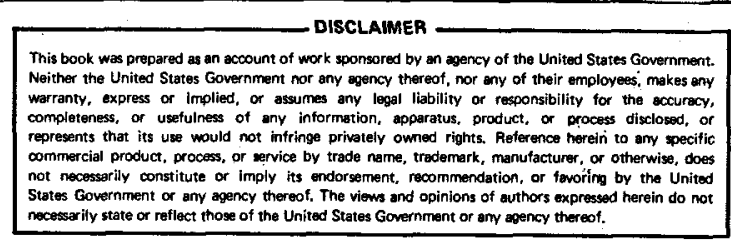

Prepared for the U.S. Department of Energy under contract W-7405-ENG-48 


\section{DISCLAIMER}

This report was prepared as an account of work sponsored by an agency of the United States Government. Neither the United States Government nor any agency Thereof, nor any of their employees, makes any warranty, express or implied, or assumes any legal liability or responsibility for the accuracy, completeness, or usefulness of any information, apparatus, product, or process disclosed, or represents that its use would not infringe privately owned rights. Reference herein to any specific commercial product, process, or service by trade name, trademark, manufacturer, or otherwise does not necessarily constitute or imply its endorsement, recommendation, or favoring by the United States Government or any agency thereof. The views and opinions of authors expressed herein do not necessarily state or reflect those of the United States Government or any agency thereof. 


\section{DISCLAIMER}

Portions of this document may be illegible in electronic image products. Images are produced from the best available original document. 
TABLE OF CONTENTS

ABS TRACT

INTRODUCTION 3

GEOLOGIC SETTING : 5

Lithology 5

Remote Sensing 10

$\begin{array}{ll}\text { Structure } & 10\end{array}$

Geothermal Resources $\quad 15$

GROUNDWATER GEOCHEMISTRY 16

Specific Electrical Conductivity 18

GEOPHYSICAL STUDIES $\quad 22$

Temperature Gradient Surveys $\quad 22$

Gravity $\quad 22$

Aeromagnetics $\quad 24$

Regional Magnetotelluric Results 26

ELECTRICAL RESISTIVITY SURVEYS

$\begin{array}{ll}\text { Spence Mountain Area } & 35\end{array}$

Geologic Interpretation of the Model DDG $\quad 40$

Other Data in the Spence Mountain Area 41

Round Lake, Long Lake, and Weyerhaeuser Mill Areas $\quad 44$

Geologic Interpretation of Models DDA, DDL, DDD, AND DDH 52

Whiteline Reservoir Area $\quad 56$

Synthesis and Geologic Interpretation of Resistivity Models $\quad 60$ 
EVALUATION OF EXPLORATION METHODS

General Observations

CONCLUSIONS

General Observations

REFERENCES CITED

APPENDIX I: KLAMATH BASIN GEOTHERMAL RESOURCE BIBLIOGRAPHY 


\section{ABSTRACT}

Data from public and private sources on the Klamath BasIn geothermal resource are reviewed, synthesized, and reinterpreted. In this, the second and final phase of the work, geological, remote sensing, geochemical, temperature gradient, gravity, aeromagnetic, and electrical resistivity data sets are examined. These data were derived from surveys concentrated on the east and west shores of Upper Klamath Lake.

The geological, remote sensing, and potential field data suggest a few northeast-trending discontinulties, which cross the regional northwesterly strike. The near-surface distribution of warm water appears to be related to the Intersections of these lineaments and northwest-trending faults.

The groundwater geochemical data are reviewed and the various reservoir temperature estimates compared. Particular attention is given to specific electrical conductivities of waters as an interpretational aid to the subsurface resistivity results. A clear trend emerges in the Klamath Falls/0lene Gap area; hotter waters are assoclated with higher specific conductivities. In the Nuss Lake/Stukel Mountain area the opposite trend prevails, although the relationship is somewhat equivocal.

The electrical resistivity data include Schlumberger, dipole-dipole, electromagnetic, and roving dipole survey results. Two-dimensional computer modeling techniques are used to develop a subsurface picture of the west shore of the lake. Extensive conductive bodies of less than 25 ohm-m appear to underlie the entire west shore area at depths ranging from 1,200 to $10,000 \mathrm{ft}$. The top of the conductive zone is consistently sha1lower beneath the valley areas. The conductive bodies may represent conductive rock formations such as clay or altered tuffs, or may be the result of 
saturation with hot geothermal brines.

The various geological, geochemical, and geophysical tools are evaluated on a site-specific basis. An integrated approach is recommended because joint interpretation of two or more spatially overlapping data sets provides more information than separate interpretation. 


\section{INTRODUCTION}

The Klamath Basin, located in south-central Oregon and northern Calffornia (Fig. 1), has been a locus of geothermal exploration activities for many years. Interest in the basin has been stimulated by the presence of numerous hot springs and over 400 wells, ranging in depth from 90 to $1900 \mathrm{ft}$, and containing waters of 60 to $145^{\circ} \mathrm{C}$. The resource is currently used for domestic, institutional, and business heating, as well as for a few agribusiness projects near the C1ty of Klamath Falls. Three known geothermal resource areas (KGRAs) have been identified in the region (F1g. 2): (1) Klamath Falls KGRA north and northeast of the C1ty of Klamath Falls; (2) Olene Gap KGRA southeast of the c1ty; and (3) Klamath Hills KGRA south of the town. Direct use of the hot water has occurred primarily within the Klamath Falls KGRA, and currently the city government of Klamath Falls, with support from the U.S. Department of Energy and the State of Oregon, has embarked on a project to develop a district heating system for the city.

Outside the Klamath Falls KGRA, geothermal developers have performed rather extensive exploration, relying mainly on electrical and electromagnetic methods coupled with studies of the reglonal geology and water geochemistry. Two unsuccessful deep holes have been drilled thus far in the search for a higher temperature resource suitable for electric power generation, and the general level of interest in the area has declined in recent years.

Working with the State of Oregon's Department of Geology and Mineral Industries (DOGAMI) and the U.S. Geological Survey (USGS), the Geothermal Group at Lawrence Berkeley Laboratory's Earth Sclence Division has attempted to collect all avallable exploration data pertalning to the area. The 


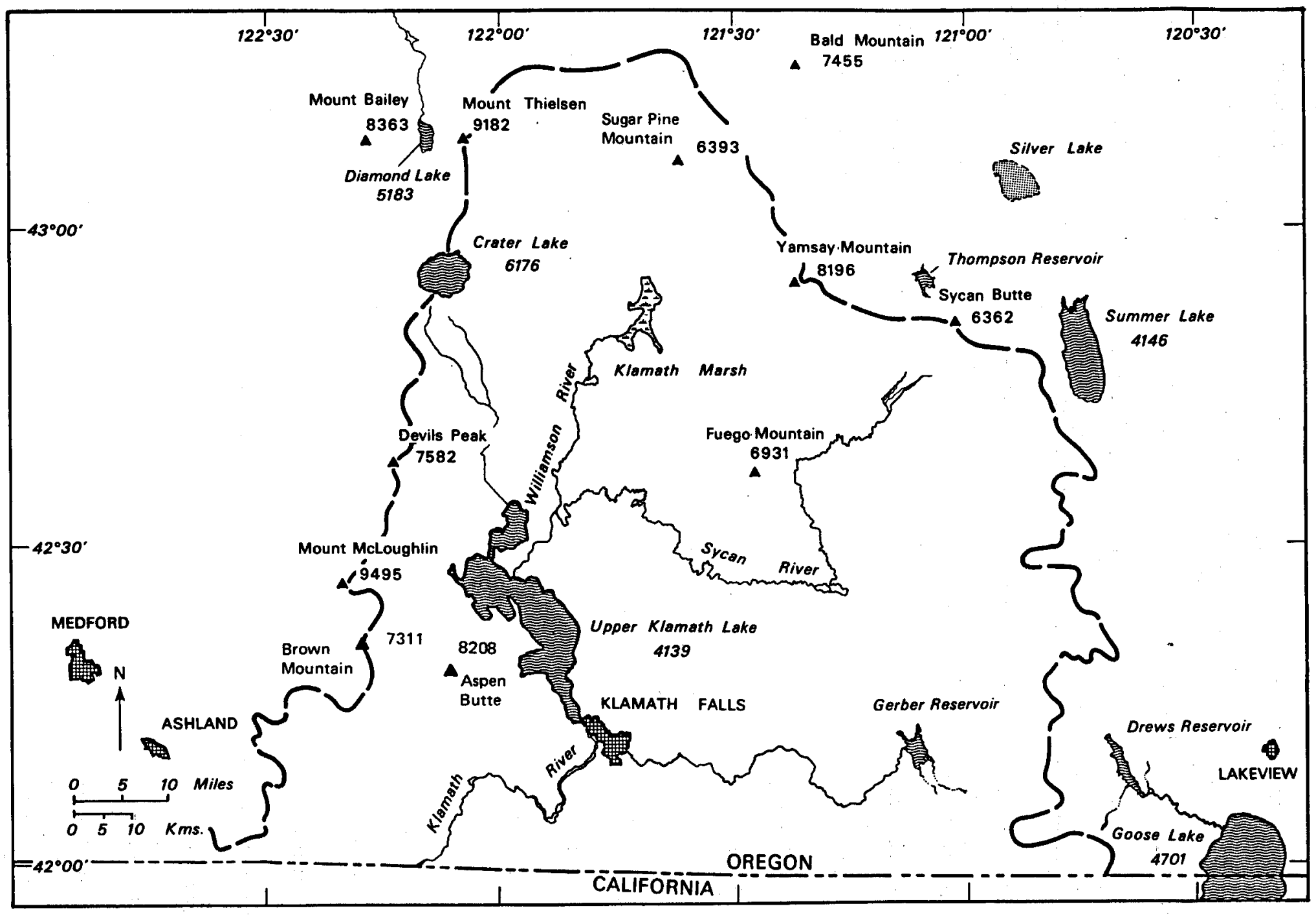

XXL $784-1822$

Figure 1. Location map of the Klamath Basin, Oregon. 
group has also compiled, assessed, and interpreted these data to develop conceptual models for geothermal reservoirs that might help guide future exploration in this area.

This report is the second and final in the series; the first (Stark, et al., 1979) was concerned with the Swan Lake Valley and the general area south of the City of Klamath Falls, Including the Olene Gap and Rlamath Hills RGRAs. This report concentrates on the remaining data, those from areas bordering Upper Klamath Lake (Fig. 2). For completeness we repeat some of the background information from the first report.

Data for this study have come from the open literature and from private companies who made their proprletary data avallable to LBL. The data base consists of over 100 documents, listed In Appendix 1.

\section{GEOLOGIC SETTING}

The geologic setting of the Klamath Basin has been described by Peterson and McIntyre (1970). The Klamath Basin is bounded by the High Cascades to the west, the Medicine Lake Highlands to the south in Callfornia, and the high desert country to the east. The basin is drained by the tributaries of the Klamath River, which flows southward into California before discharging into the Pacific Ocean.

\section{Lithology}

The stratigraphic section in Figure 3 shows the rock units recognized by Peterson and McIntyre. The basement rock consists of Pliocene basalts of undetermined thickness. These are unconformably overlain by the Pliocene Yonna Formation, a sequence of tuffaceous siltstones and sandstones, lacustrine sediments (largely diatomite), and basalt flows (Newcomb, 1958). The Yonna rocks are subaqueous deposits formed during 
Known geothermal resources orea boundary
Dipole - dipole and Schlumberger survey area ( Harding - Lawson, 1974)

-- Schlumberger sounding and roving dipole survey area (Geoterrex, 1975)

-- Schlumberger, time domain electromagnetic, and roving dipole survey area (Argonaut, 1975)

Gravity and magnetics (VanDeusen, 1978) covers whole area

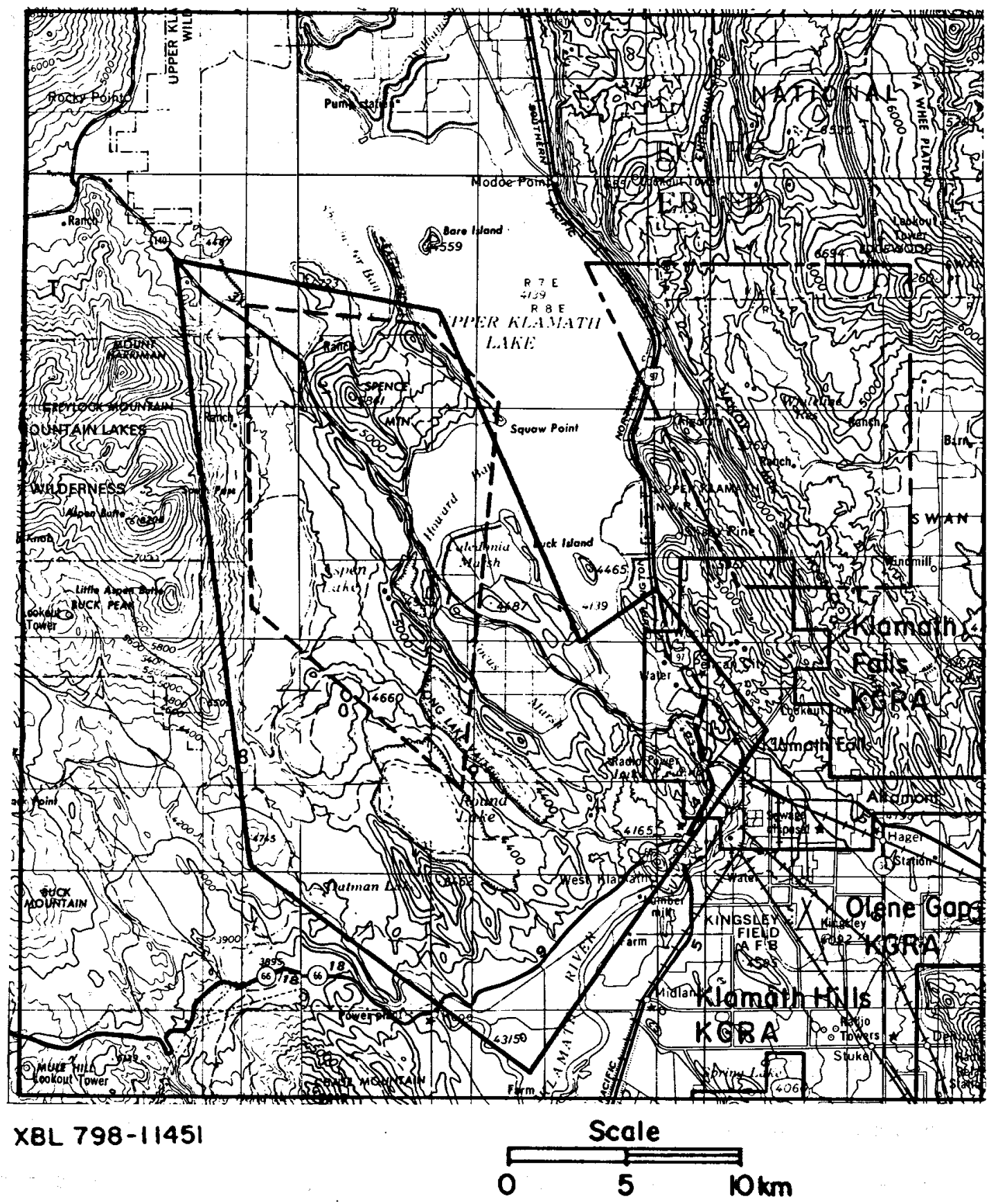

XBL 798-11451

Figure 2. Index map of geophysical survey areas. 


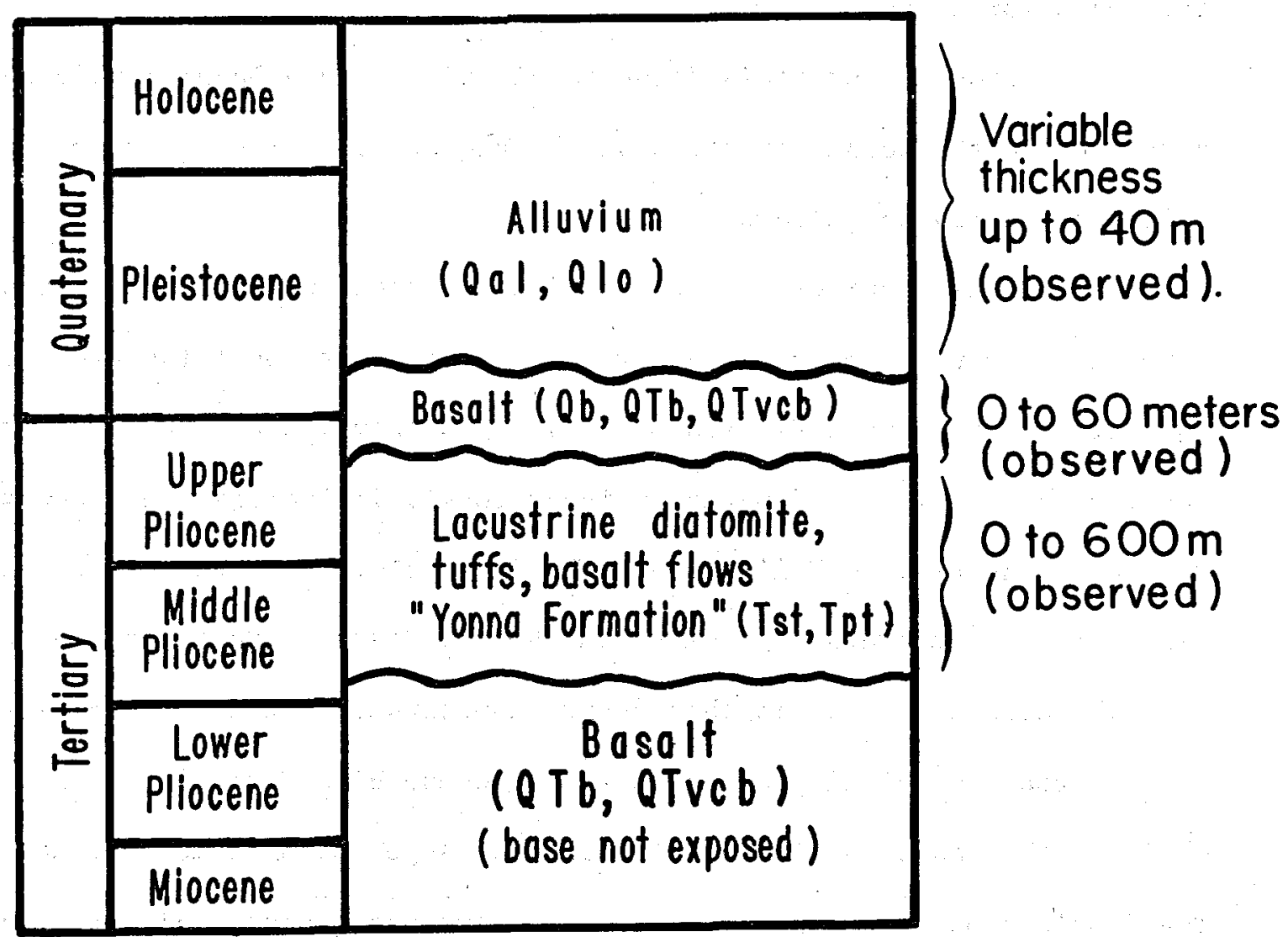

XBL 7810-6540

Figure 3. Stratigraphic column for the Klamath Falls area (after Peterson and McIntyre, 1970). 
a period when the region was covered by lakes and swamps. Explosive and quiescent volcanism were nearly contemporaneous with deposition, as evidenced by maars, tuffs, and thin basalt flows in the Yonna Formation. Newcomb (1958) reports a maximum observed thickness of about $600 \mathrm{~m}$ for the Yonna Formation.

Late P1locene and Plefstocene basalt flows and volcaniclastic interbeds overlie the Yonna Formation at the higher elevations. Quaternary alluvium covers the valleys.

Groundwater aquifers exist in all these rock units, but the Yonna Formation includes impermeable strata, which act as confining beds for aquifers below. Upper Klamath Lake averages only $2.4 \mathrm{~m}$ in depth, but contains $7.2 \times 10^{8} \mathrm{~m}^{3}$ of water, which strongly influences the groundwater regime In the Klamath Falls area. The lake water tends to obscure the near-surface temperature gradient in the Immediate vicintty of the lake.

The area discussed in this report constitutes a transitional zone between two geological provinces, the Holocene High Cascade volcanic chain to the west, and the arid Basin and Range geomorphology to the east. The distinction is well expressed in the surface geology (Fig. 4). Thick andesite and basalt flows predominate in the Cascades, extruded from Quaternary volcanic centers such as Brown Mountaln, Aspen Butte, and Mt. McLoughlin (Fig. 1). Some of the basaltic flows may have reached the Klamath Basin, appearing as the younger basalt unit in the stratigraphic column (Fig. 3).

The flows are mostly dense and hard, with fractured flows or scorlaceous tops serving as aquifers. No active volcanism has been reported, the most recent known eruption being the cataclysmic Mt. Mazama event about 6,700 years ago. The youngest volcano in the immediate area 


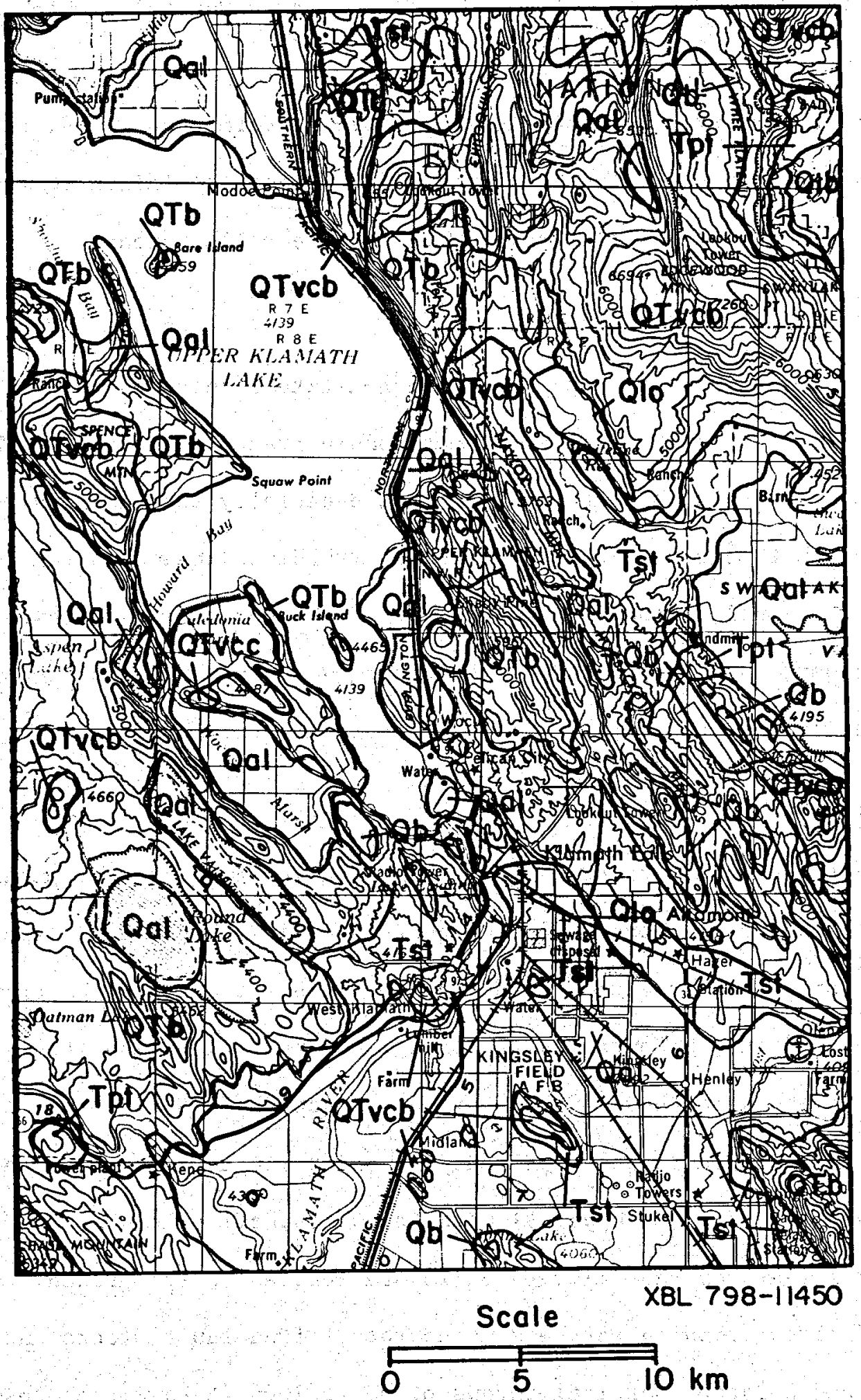

Figure 4. Surface 11thologic map (after Peterson and McIntyre, 1970). See Figure 3 for description of rock units. 
west of the Upper Rlamath Lake appears to be Brown Mountain, which may have erupted in Holocene time.

The eastern area is characterlzed by Yonna Formation rocks, unconformably underlain (and possibly overlain) by basalts simflar to those of the Cascades. Alluvial fill covers most of the valley areas.

\section{Remote Sensing}

We obtained four stereo-matched high-altitude infrared photographs, scale 1:125,000, of the central Klamath Basin area (EROS, 1979). They dramatically display structural features, especially the numerous northwesttrending fault scarps. Several northeast-trending lineaments can be discerned as well, although they are not as obvious as the northwest trending set; they are marked by tone changes and/or anomalous topography. The locations and meaning of these linaments are discussed below.

\section{Structure}

The structural setting of the Klamath Basin is somewhat typical of the Basin and Range geomorphic province. The Klamath graben is the predominant structural feature, trending $N 40^{\circ} \mathrm{W}$ and extending $80 \mathrm{~km}$ from the southern portions of Lower Klamath Lake to Crater Lake. The trend can also be followed another $100 \mathrm{~km}$ southeast, through Tule Lake and Alturas, California. Figures 5 and 6 present the major faults identified on the west and east shores of Upper Klamath Lake, respectively. Many of the smaller structural features near Klamath Falls are related to the graben. Numerous normal faults, trending northwest, separate tilted fault blocks and parasitic grabens and horsts. Vertical throws of up to $1600 \mathrm{ft}$ have been observed on steeply dipping exposed fault scarps (e.g., Rattlesnake Point and Stukel Mountain). The historical record of earthquakes indicates that the area is still seismically active. 


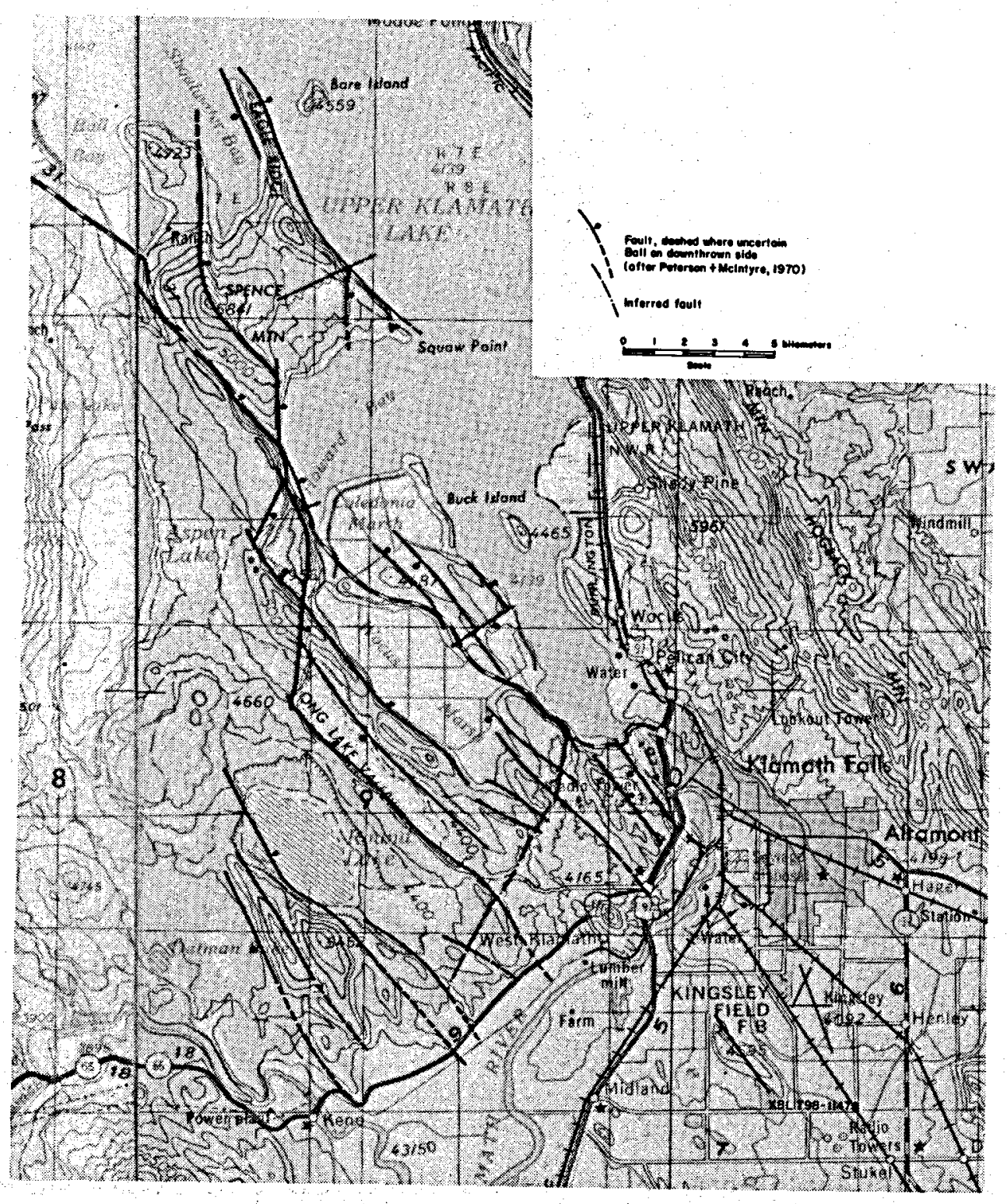

Figure 5. Locations of faults, west shore of Upper Klamath Lake. 


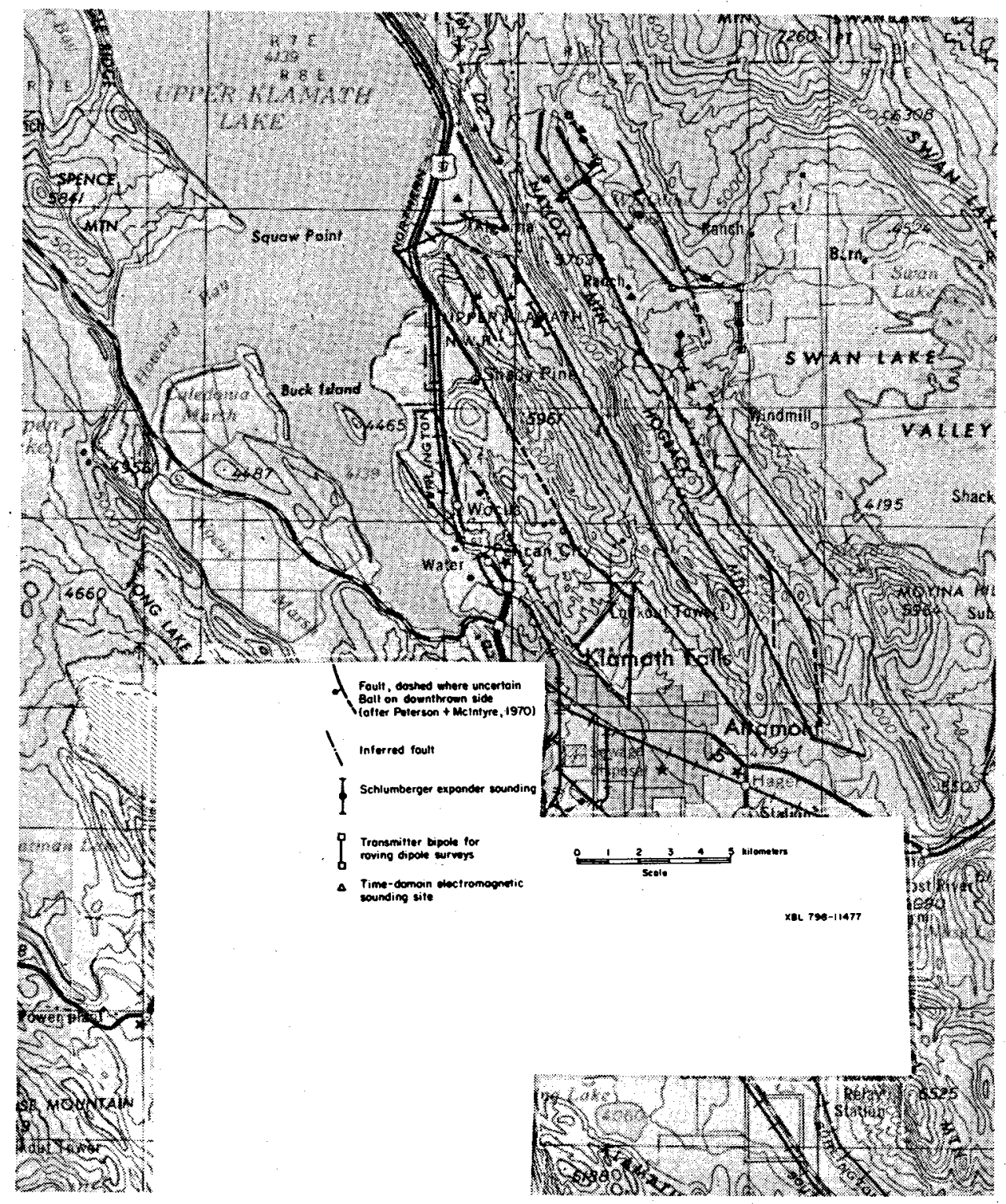

Figure 6. Locations of faults and electrical resistivity surveys, east shore of Upper Klamath Lake. 
Most faults on the east shore of Upper Klamath Lake dip southwesterly, while those on the west shore dip northeasterly, suggesting that the axis of the graben passes through the lake. The fault pattern is made more complex by the presence of short north and northeast-trending cross-faults. Geophysical and remote sensing evidence has led us to Infer longer northeast-trending cross-faults: one passing through olene Gap and Spring Lake Valley (Stark et al., 1979), another northwest of the Klamath River and Lake Ewauma, and a third east of Klamath Falls. The latter two faults are discussed in this report and are shown in Figures 5 and 6.

There is a sharp bend in the graben trend from $140 \%$ to almost due north, In the northern portion of Upper Klamath Lake. The bend is reflected in changes in the strike of faults and topographic "grain" at Spence Mountain, Eagle Ridge, Modoc Point, Chiloquin Ridge; and the Ya Whee Plateau Rim (Fig. 7). Spence Mountain is a particularly good example; the mountain peak is located at the intersection of the two trends.

The graben is also strongly distorted in the Klamath Falls area, but the distortion there is more complex. The flanks seem to neck together near the city; further south the graben opens up into a broader basin contalning scattered horst blocks. Two of the above-mentioned northeasttrending faults are located south of the city. One runs south of Round Lake and Long Lake, ending near the southern' tip of Upper Klamath Lake. The other crosses Spring Lake Valley, from the Klamath Hills past the northern t1p of Stukel Mountain and on through 01ene Gap. The graben appears to be offset along these faults in the right-lateral sense, its axis shifting from Upper Klamath Lake southwest to the Lower Klamath Lake Basin as depicted in Figure 7. This offset may be an expression of a 


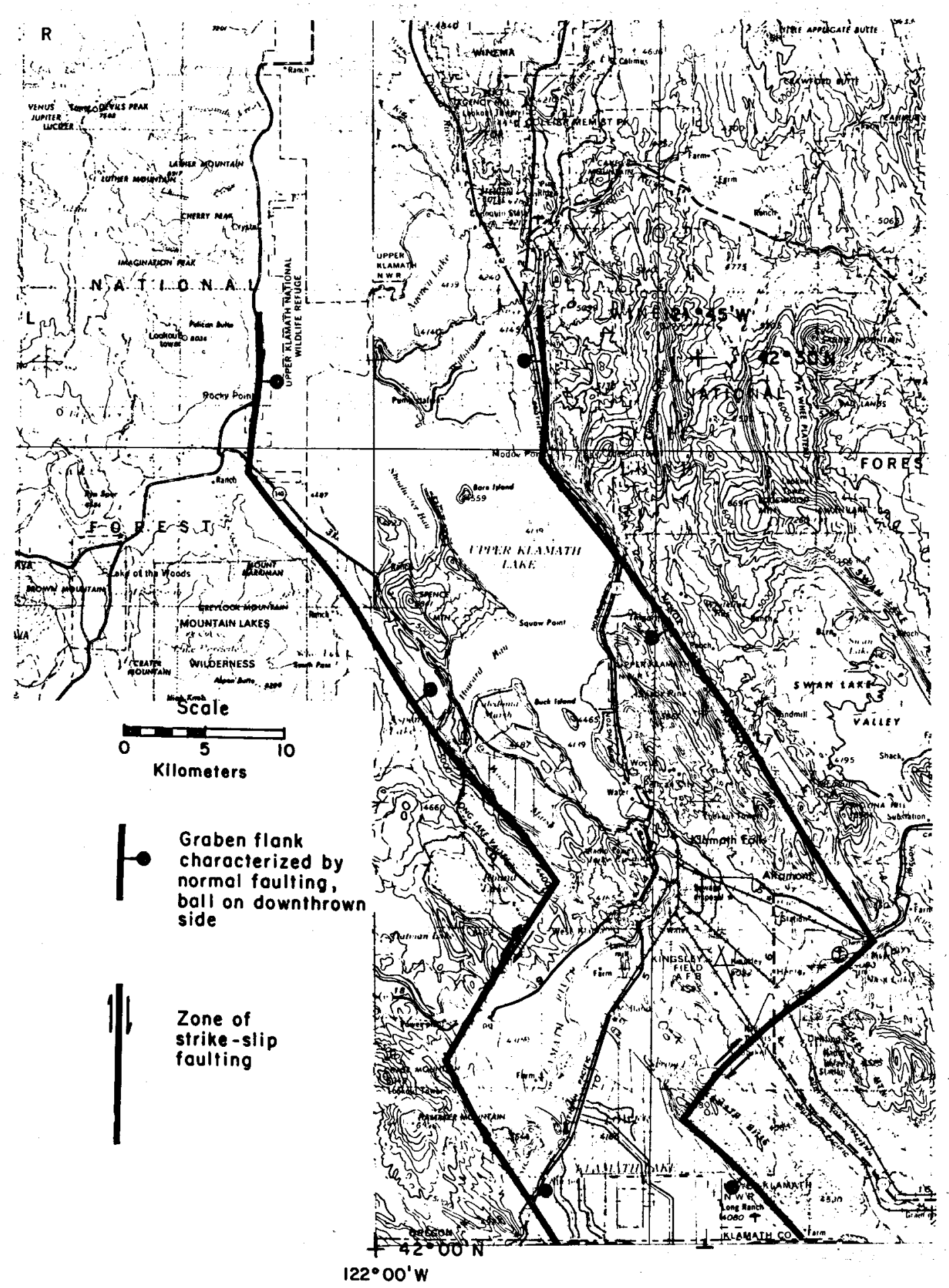

XBL $7910-13077$

Figure 7. Schematic tectonic map of Klamath graben. 
major northeast-trending discontinuity, which extends through southern Swan

- Lake Valley (Stark et al., 1979) and beyond. Within the Klamath graben, smaller components of left-lateral and dip-slip motion might be expected along these cross-faults, accomodating the strain caused by the graben offset.

This is at best a grossly oversimplified model of the graben. A glance at the topography in Figure 7 shows that the eastern boundary of the graben is difficult to Identify. It is not clear whether Swan Lake Valley and the valley between the Klamath HIlls and Stukel Mountain can be properly considered as part of the Klamath graben. On the western margin (Fig. 5), the northwest-trending normal faults seem to continue some distance into the Round Lake and Long Lake areas. These complications may be related to the "wrench-faulting" concepts used to explain features of continental rift zones.

No major faults are mapped in the High Cascades region west of Klamath Falls, although some of the normal faults in the graben extend a few kilometers into the mountains.

\section{Geothermal Resources}

The three KGRAs are shown in Figure 2. Klamath Falls KGRA encompasses the principal hot well area in the town and extends east-northeastward. A detalled description of the Klamath Falls geothermal setting is given by Lund et.al. (1978). Hot water has been used by the residents, mainly for space heating, since the turn of the century. Presently, approximately 400 shallow wells, mostly 200 to 300 ft deep, are used to heat 500 structures. Water temperatures range up to $145^{\circ} \mathrm{C}$. The main hot water well area is located adjacent to one of the fault scarps forming the eastern boundary of the Klamath Lake graben. 
Neither geophysics nor drilling have probed the deep geothermal system at Klamath Falls. For this reason, we have not investigated the area at length in our work. However, based on the extensive shallow geothermal mantfestations, we feel that the urban area merits further exploration.

Olene Gap KGRA covers an area which includes much of the northern and western portion of Stukel Mountain. Geothermal manifestations include a few wells and springs with temperatures up to $87^{\circ} \mathrm{C}$ in Olene Gap, and a few warm wells with temperatures up to $42^{\circ} \mathrm{C}$ near the northwestern tip of Stukel Mountain.

Klamath Hills KGRA contains two hot wells $\left(>90^{\circ} \mathrm{C}\right)$ and a few warm wells along the southwestern margin of the hills.

\section{GROUNDWATER GEOCHEMISTRY}

Extensive geochemical work was carried out by Geothermex for Weyerhaeuser (Appendix 2, File 72-11-27), and by the U.S. Geologic Survey (Samme1, 1976). Geothermex sampled 78 springs and 16 wells in an area of $26,000 \mathrm{~km}^{2}$. Their work covered the entire $\mathrm{Klamath}$ Basin, as well as outlying areas in the Cascades, the Crater Lake area, and the Goose and Summer Lake valleys. The samples were analyzed for temperature, $\mathrm{pH}$, and flow rate. Measurements for carbonate and bicarbonate lons were made in the field; calcium, magnestum, sodium, potasium, silica, chloride, bicarbonate, sulfate, boron, fluoride, bromide, and nitrate ion contents were determined in the laboratory.

Two principal water types were recognized by Geothermex: a cool b1carbonate water with low total dissolved solids (TDS) found mainly in the mountainous areas, and a warmer bicarbonate-chloride-sulfate water with higher TDS, more common in the structural basins. A few waters of 
intermediate composition and temperature were sampled; presumably these are mixtures of the two types.

Geothermex estimated the equilibration temperature of the hot aquifer using $\mathrm{SiO}_{2}$ and $\mathrm{Na}-\mathrm{K}-\mathrm{Ca}$ geothermometers, obtaining values of $120^{\circ} \mathrm{C}$ and 80 to $100^{\circ} \mathrm{C}$, respectively. They also reasoned that the anomalously high values of $\mathrm{SO}_{4}$ observed in the warmer waters could represent oxidized $\mathrm{H}_{2} \mathrm{~S}$ from a deeper steam reservoir. Such a steam reservoir would not affect the hot-water equilibria for the $\mathrm{SiO}_{2}$ and $\mathrm{Na}-\mathrm{K}-\mathrm{Ca}$ geothermometers.

Sammel (1976) analyzed over 300 wells and springs, primarily in the Klamath and Lost River valleys and near Lower Klamath Lake. Temperature and specific electrical conductivity were measured at most wells and springs; also measured in wells were depth, water level, and discharge rate. Thirty-five waters were chemically analyzed for silica, calcium, magnesium, sodfum, blcarbonate, carbonate, sulfate, chloride, fluoride, arsenic, boron, Iron, 11thium, and manganese. In addition, preexisting chemical data from another 22 wells were Inventoried, making a total of 57 waters available for geochemical interpretation. Sammel made reservoir temperature estimates based on sllica and $\mathrm{Na}: \mathrm{K}$ equilibria. He also Investigated the applicability of mixing models that account for dilution of geothermal fluids with groundwater, and examined the possibility of reservolr equilibration with more soluble forms of silica, such as chalcedony. He estimated a minimum reservolr temperature of 124 to $130^{\circ} \mathrm{C}$, which is similar to the Geothermex estimates. He also felt that there is little mixing of groundwater with deeper hot water and that the maximum temperature in the hot-water aquifer is probably not substantially higher than $130^{\circ} \mathrm{C}$. Sammel also considered the possibility of a deeper steam reservoir, using the same reasoning as the Geothermex workers.

Since the publication of these studies, a 1200-ft well has been 
drilled in the Klamath Falls "steamer zone," with a reported bottom-hole temperature of $145^{\circ} \mathrm{C}$ (C. Goranson, oral commun.), which is $25^{\circ} \mathrm{C}$ hotter than measured in other wells in the basin. Temperatures as high as $120^{\circ} \mathrm{C}$ have been recorded previously in non-producing zones above the hot water aquifer, but water hotter than $113^{\circ} \mathrm{C}$ has not been produced. It is not yet known whether this new well can sustain production.

\section{Specific Electrical Conductivity}

Samme1 (1976) measured the electrical conductivity of most of the well and spring waters, correcting the measurements in the field to $25^{\circ} \mathrm{C}$ to obtain specific conductivity, data. This quantity, then, is not the the true conductivity of the water in situ, but is the estimated conductIvity of the water if it were measured at $25^{\circ} \mathrm{C}$.

These measurements were especially interesting to us as an aid to interpreting the resistivity survey data. Most rock materials are poor electrical conductors compared with the pore fluids they contain, so that, Ignoring surface conduction effects, the minimum possible formation resistivity is close to the resistivity of its pore fluid.

We converted Sammel's specific conductivities (in $\mu \mathrm{ohm} / \mathrm{cm}$ ) to specific resistivities (in ohm-m), and extrapolated to true fluid resistivity using empirical graphs by Keller and Frischknecht (1966, p. 19). That is, using these graphs we estimated the resistivities of the waters at their reported temperatures. The data from Klamath Falls, Altamont, and Olene Gap are plotted on log-log scale in Figure 8. There is an approximate straight-line trend here, although the data are severely clustered into two groups: hot conductive waters and cool resistive 


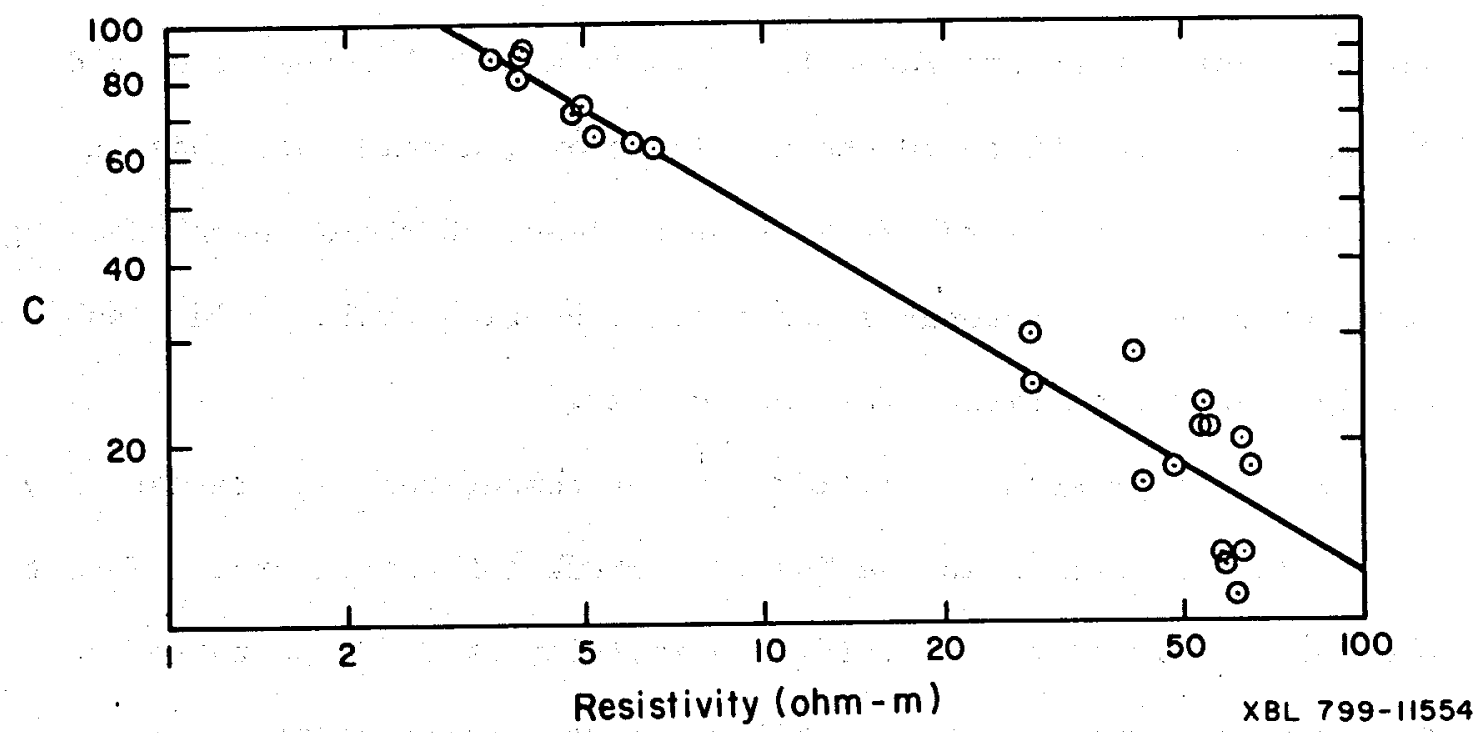

Figure 8. Resistivity vs temperature for Klamath Falls/Olene Gap waters.

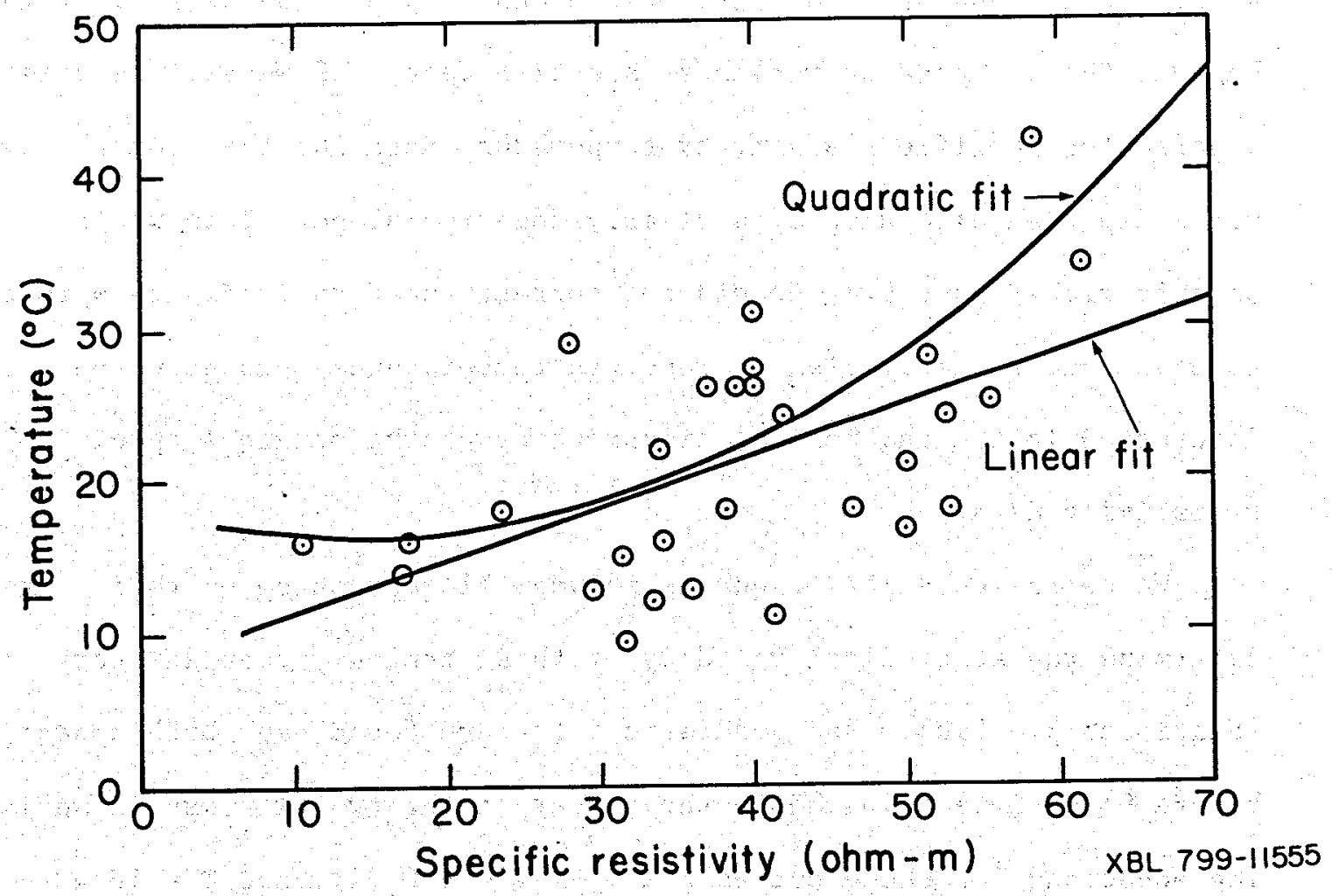

Figure 9. Specific resistivity vs temperature for Nuss Lake/Stukel Mountain waters. 
waters. The hot waters range from 3.5 to almost 7 ohm-m; the cold waters range from 60 to $70 \mathrm{ohm}-\mathrm{m}$. Therefore, a cold-water basalt aquifer should have a resistivity of at least $60 \mathrm{ohm}-\mathrm{m}$, even assuming $100 \%$ porosity. A reasonable porosity assumption would yield a substantially higher resistivity for the aquifer.

Figure 9 presents a similar plot of temperature vs. resistivity for wells and springs in the Nuss Lake/Stukel Mountain area. Note that the abscissa is labeled specific resistivity at $25^{\circ} \mathrm{C}$, so these values have not been recalculated to their reported temperatures.

The temperature-resistivity relationship here is less clear, but it appears to have a positive slope. This is just the opposite of what we found for the Klamath Falls/Olene Gap waters, and is contrary to what one would expect. Comparison of Figures 8 and 9 is not quantitatively valid because the independent variables are different. (However, the original uncorrected specific resistivity-temperature data for the Klamath FallsOlene Gap area also display a clearly negative slope. This would be comparable with Figure 9.) We did not correct the data in Figure 9 to calculated true resistivities at reported temperatures because we became interested in the geochemical significance of the original specific resistivity data.

We performed a least squares polynomial regression on these data to determine the statistical validity of this seemingly contradictory relationship. Linear and quadratic fits were found, and both appear in Figure 9; an F test to choose the better of the two fits was inconclusive. The equations for these curves are $T=7.71+0.34 \rho$, and $T=18.48-0.30 \rho$ $+0.010^{2}$. The parameter $R^{2}$, which represents the proportion of the variance about the mean explained by the regression, was calculated for 
each fit; $R^{2}=0.78$ for the linear fit and $R^{2}=0.94$ for the quadratic. For the linear fit a Pearson correlation coefficient of 0.54 was obtained. These numbers indicate that the anomalous trend in the data is valid, but only marginally so. We are thus left to explain why the warmer waters in the Nuss Lake/Stukel Mountain area are more resistive than the cooler waters. In fact, the warmest waters plot at about $60 \mathrm{ohm}-\mathrm{m}$, similar to the values observed for the coldest waters in Figure 8a, while the colder waters in Figure 9 are in the 10 to 20 ohm-m range.

Sammel (1976) noted the high conductivity of the cold groundwater In the Nuss Lake area, attributing this to long residence and cooling times in a warm, marshy environment. This would certainly explain the cold conductive waters. The warm resistive waters are more difficult to understand. We recommend making repeat measurements of some of the warmer waters, and new measurements on any unsampled waters before advancing an explanation for this phenonenon. Perhaps more detailed geochemical work could shed some light on the history of these waters.

In the light of these data, we must revise our earlier interpretations of an audio-magnetotelluric resistivity low discussed in our previous report (Stark et al., 1979). At that time we viewed the low as a possible indication of hydrothermal circulation related to a fault. Now we would allow that it is equally probable that the shallow low resistivity anomaly is caused by cooler but conductive groundwaters. Future prospectors in this area should heed these data. Electrical surveys, if used at all, should be designed to probe deeper than the conductive groundwater. It should also be borne in mind that the target may be relatively resistive. 
GEOPH XSICAL STUDIES

\section{Temperature Gradient Surveys}

We examined two shallow-hole temperature gradient surveys in the basin. One was performed for Weyerhaueser (Appendix 2, File 74-3-9) in the Nuss Lake area, and contains no analysis or interpretation. The second was done for Thermal Power (1978) in the Klamath Hills. We did not attempt a reanalysis of these surveys.

Gravity

Van Deusen (1978) made a regional gravity survey, obtaining data at 465 stations over a $3000 \mathrm{~km}^{2}$ area around Klamath Falls. Standard corrections were applied to produce free alr and complete Bouguer gravity maps. Finally, a variable density reduction scheme was used to minimize correlation with topography. In this scheme, different Bouguer correction densities were assumed for volcanic and sedimentary areas. These were allowed to vary so that a computer program could find two densities that minimized correlation between topography and geology. A portion of the variable density map, covering the area of interest in this report, is reproduced in Figure 10.

A small high of about $3 \mathrm{mgal}$ is associated with Spence Mountain, whereas the volcanic centers to the west in the Mountain Lakes W1lderness Area are characterized by a broad subreglonal 1ow, with scattered local highs and lows over individual peaks.

Further south, in the pulp mill area, the gravity contours trend northeast, crossing the regional geologic strike. This local distortion may be related to a northeast-trending fault near the margin of the valley, as shown in Figures 6 and 7. 

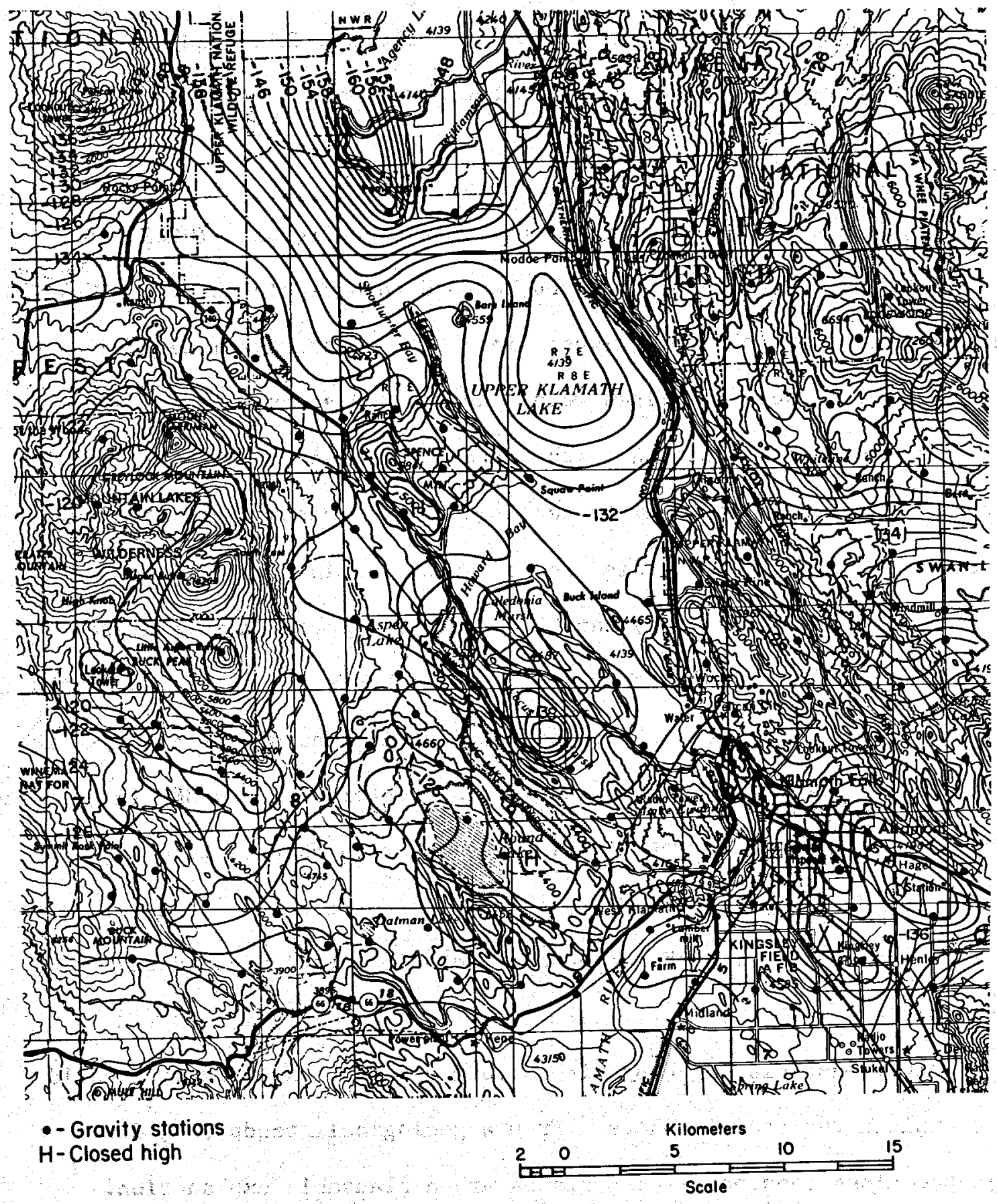

XEL $798-11476$

Figure 10. Alternate density Bouguer gravity anomaly, contour Interval = 2 mgal (after Van Deusen, 1978). 
The gravity contours follow the bend in structural and topographic trends noted in the preceding section on geology. Th1s bend can be seen In the contours near Spence Mountaln and Modoc Point.

\section{Aeromagnetics}

Van Deusen (1978) Interpreted UṢGS aeromagnet1c data (USGS, 1972 and 1973) for the Klamath Fal1s and Medford topographic sheets. These surveys were flown along east-west lines with an average ilne spacing of $3.2 \mathrm{~km}$. North-south tie lines were spaced $50 \mathrm{~km}$ apart. Applying a variable continuation scheme to the data, Van Deusen constructed an aeromagnetic map to approximate data taken at a constant elevation above topography. A portion of this map is reproduced in Figure 11.

A large dipoler anomaly can be seen in the Spence Mountain area. The symmetric anomaly, 700 gammas peak-to-peak, is not easily explained by topographic or geologic effects. It is the signature of a thick dike or prismatic body with a net magnetization vector inclined $30^{\circ}$ in an eastwest direction (Vacquier et al., 1963) and burled about $1 \mathrm{~km}$ deep. How such a source could exist in this setting is not clear; some combination of remanent magnetism with subsequent tectonic rotation could be responsible.

A thin east-dipping body with strong remanent magnetization could also explain the anomaly shape. From a geological standpoint, dikes injected along tensional fault planes are a plausable explanation. However, a dipping dike usually produces a long, 11near, asymmetric dipolar anomaly, quite different from the anomaly observed on Spence Mountain. A positive density contrast assoclated with either the dipping dike or the horizontally magnetized body could explain the small gravity high discussed above. 


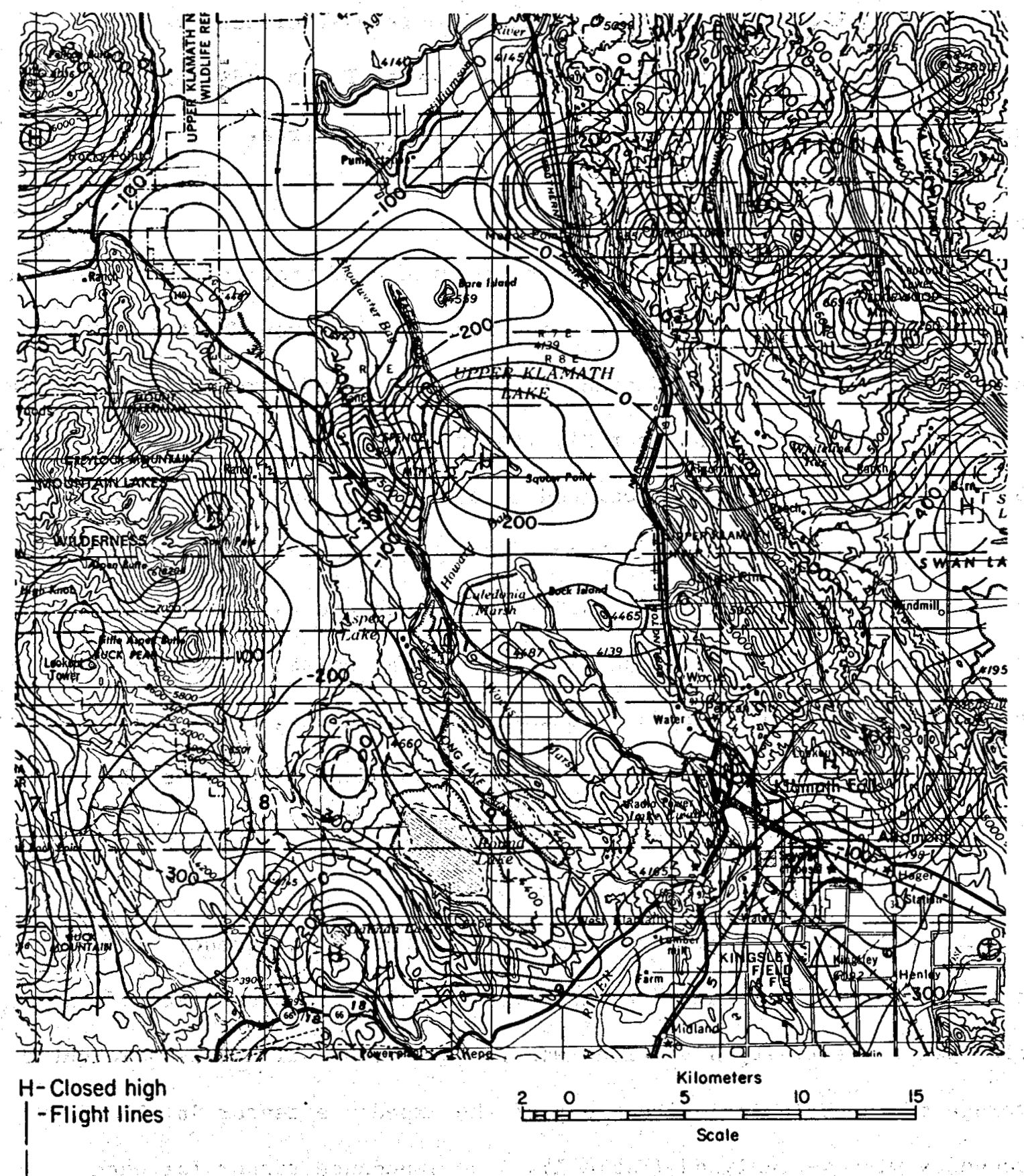

X8L 798-11475

Figure 11. Total-intensity aero magnetic survey, variable--continued to constant elevation above topography, contour interval $=100$ gammas (after Van Duesen, 1978). 
Further south in the lumber mill area the magnetic contours are aligned, like the gravity contours, in the northeast direction. In fact, this trend can be followed through Klamath Falls and on Into Swan Lake Valley, again suggesting cross-faulting in the area.

\section{Regiona1 Magnetotelluric Results}

During September 1979 , ten remote-reference MT stations were occupled by $L B L$ researchers in a line extending from the Siskiyou Mountains (Cave Junction), across the Cascades and Klamath Basin, and terminating near the eastern edge of the basin, near Bly (Figure 12). With stations spaced 8 to $15 \mathrm{~km}$ apart, the survey was designed to provide regional information in support of the U.'S. Geological Survey's High Cascade Program. Although good data were not obtained at the Provolt, Ruch and Ashland stations due to instrumental malfunctions and severe cultural noise, we were able to obtain reasonably reliable data between Parker and Bly, which together with the Swan Lake MT data between Klamath Falls and Yonna (Stark et al., 1979), permitted us to make a regional MT resistivity interpretation along a line $100 \mathrm{~km}$ in length.

At each station data were obtained for about 15 frequency windows in the $.001-.1 \mathrm{~Hz}$ band. For each station an averaged estimate of principal resisitivity directions was found. Each estimate is a weighted average of the principal directions of the Impedance tensor in all of the frequency windows analyzed (Table 1). The impedance tensor for each station data set was then rotated into the appropriate direction and the resulting off-diagonal matrix elements, $z_{x y}(\omega)$ and $z_{y x}(\omega)$, were used to determine apparent resistivities $\rho_{x y}(\omega)$ and $\rho_{y x}(\omega)$ in the principal directions. However, this procedure leaves a $90^{\circ}$ ambiguity as to the regional strike direction. Tipper strikes, based on the relationship 


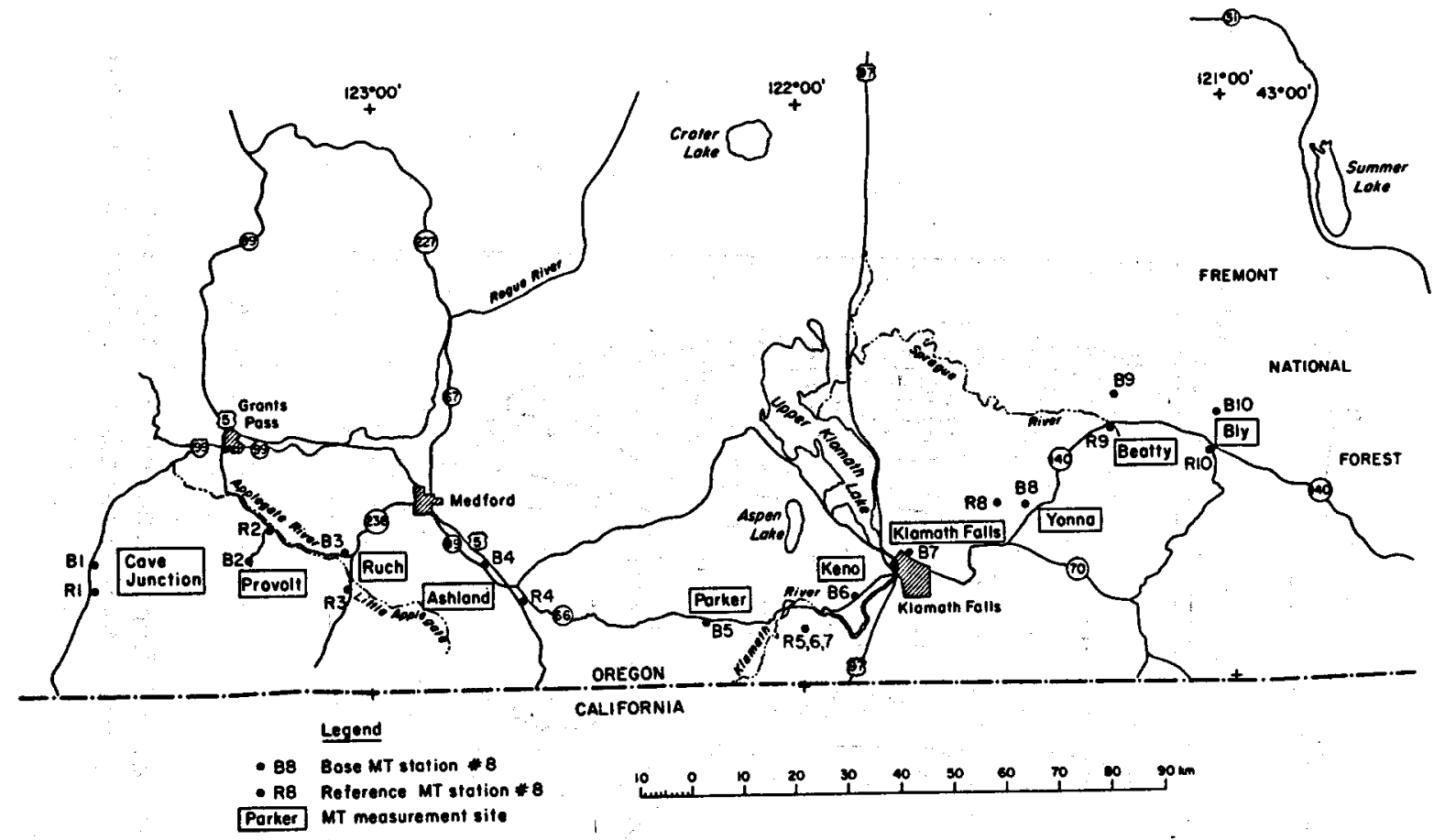

Figure 12. Magnetotelluric station location map.

$x \otimes L \cos -6823$

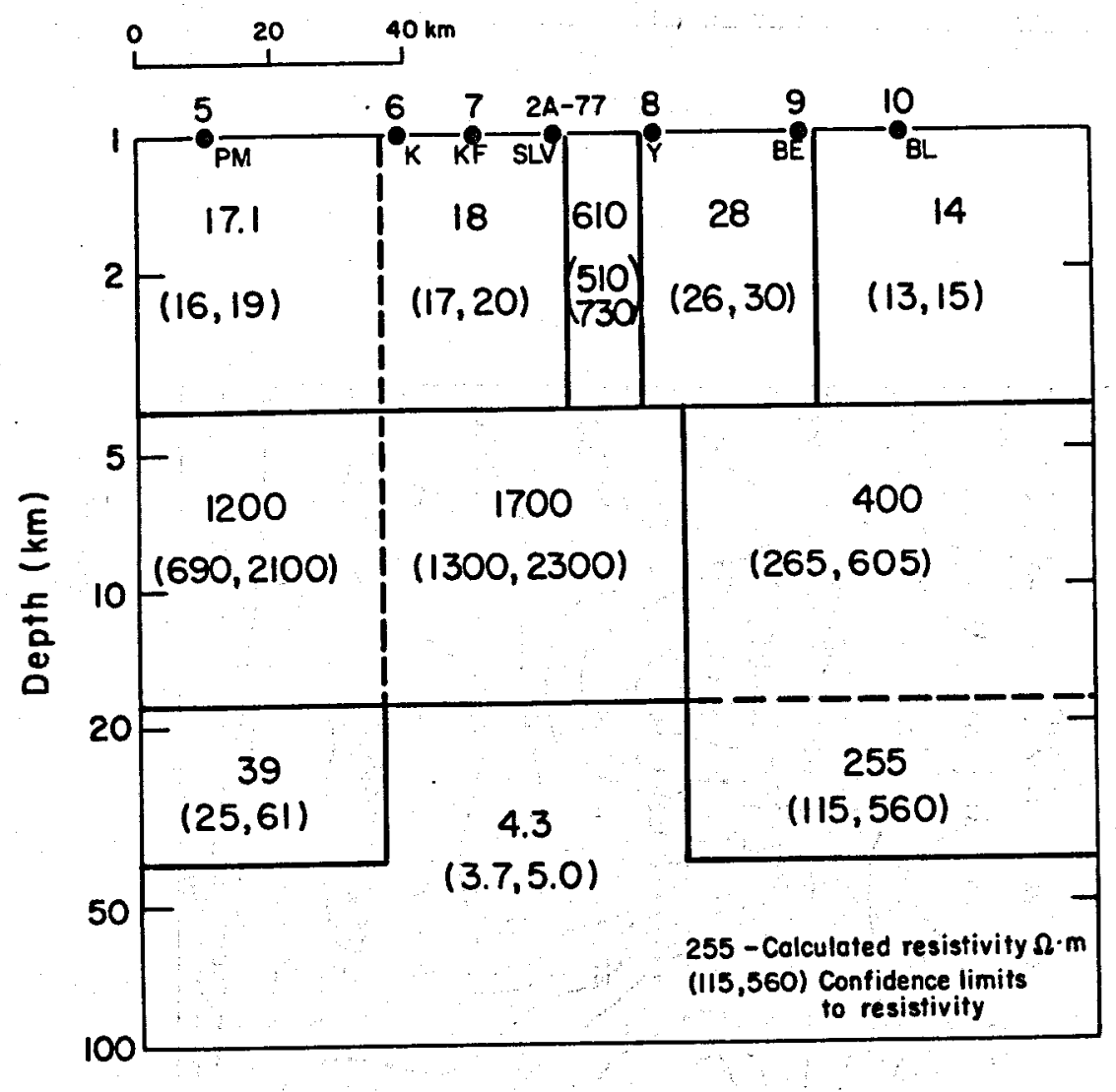

XBL $805-847$

Figure 13. Two-dimensional magnetotelluric resistivity model. 


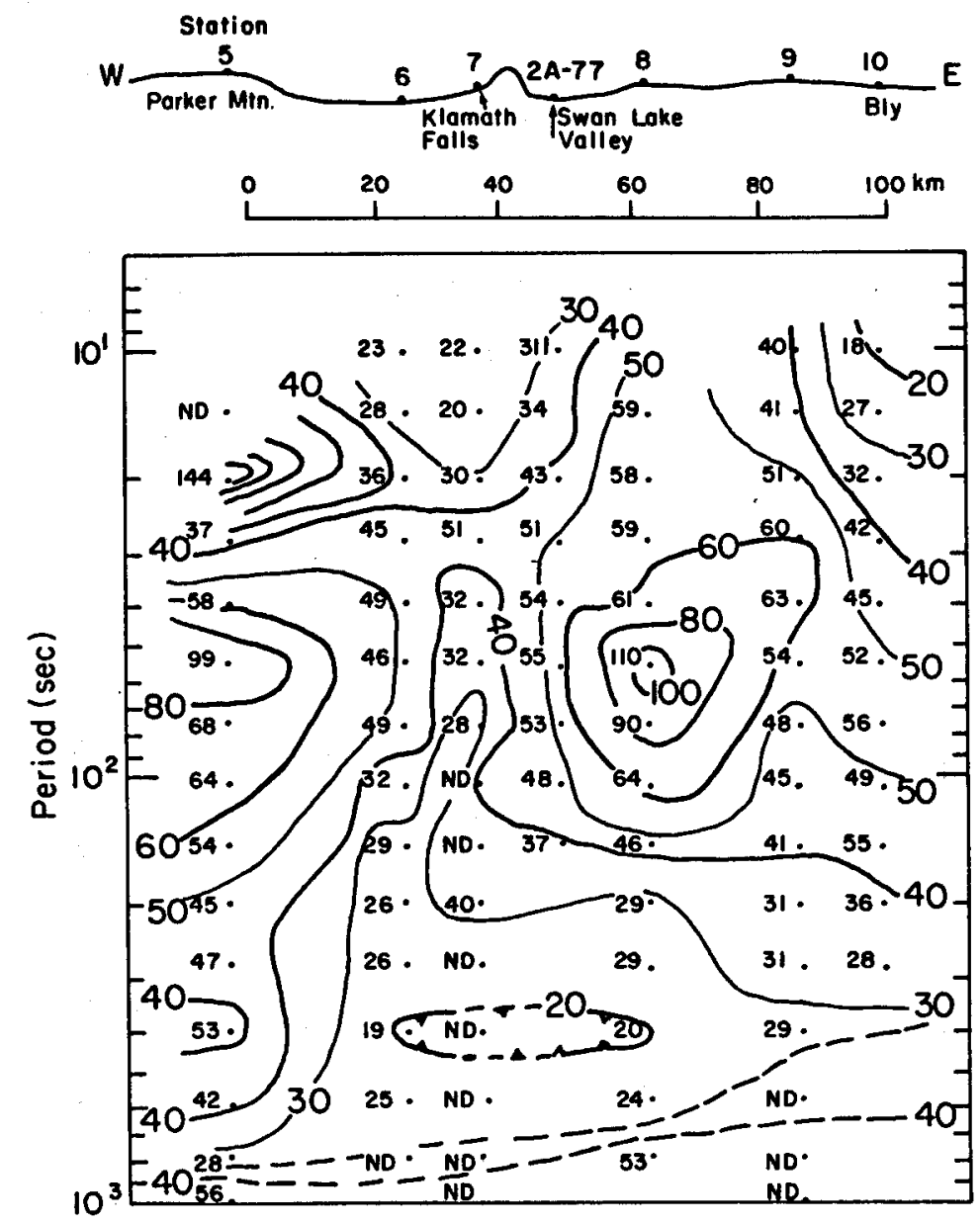

XBL 805-846

Figure 14a. Observed E-parallel apparent resistivity pseudosection, values in ohm-m.

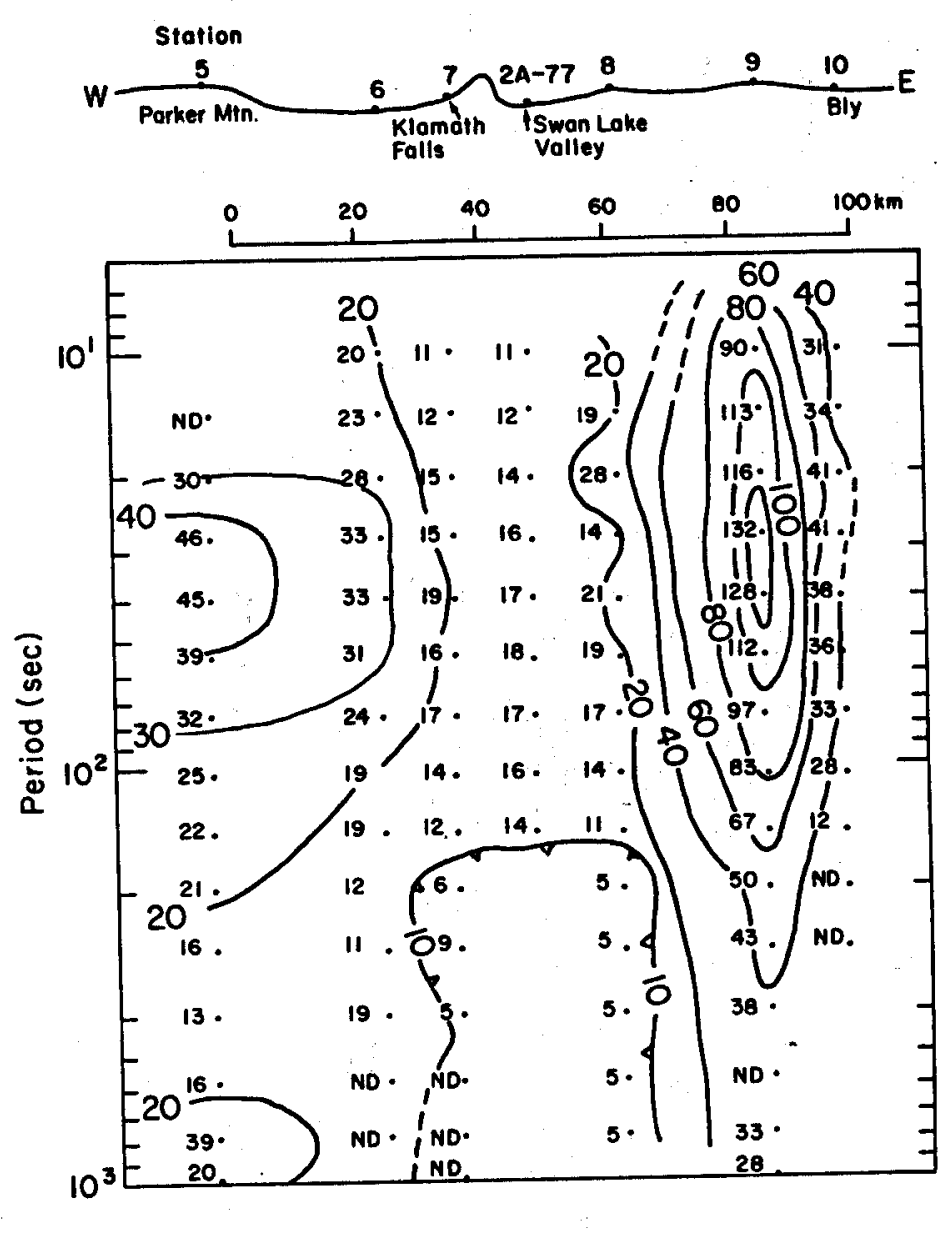

X8L $805-845$

Figure 14b. Observed E-perpendicular apparent resistivity pseudosection, values in ohm-m. 


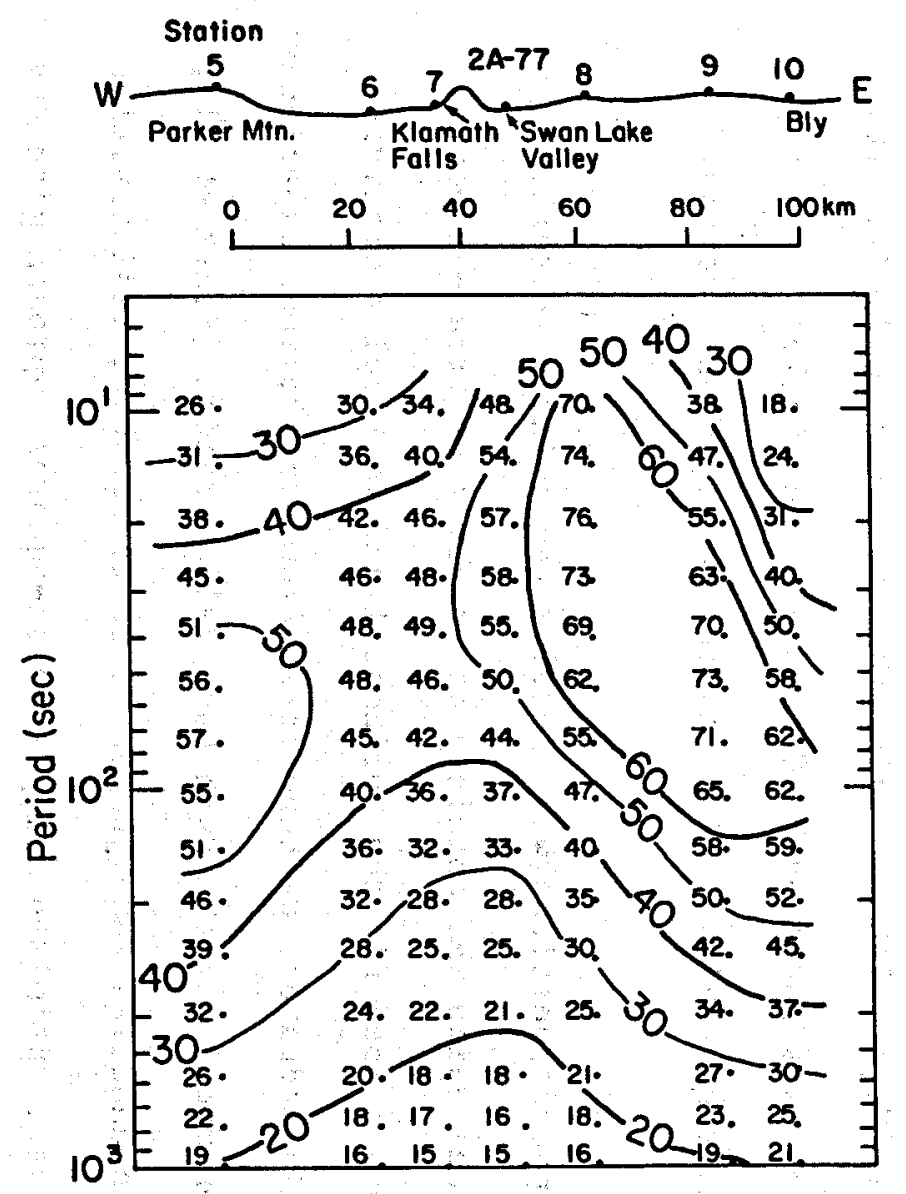

XEL805-844

Figure 15a. E-parallel apparent resistivity pseudosection calculated for two-dimensional mode1. Values in ohm-m.

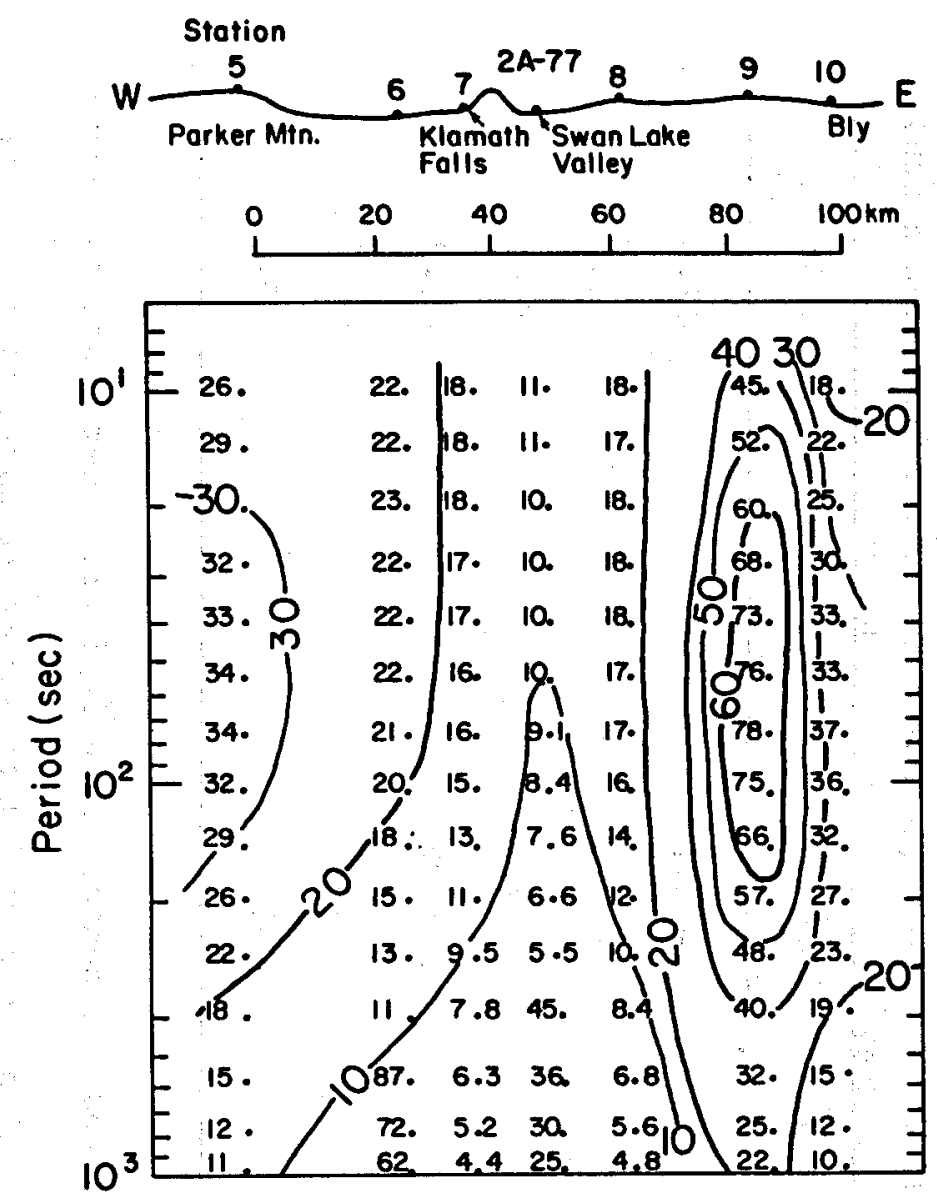

กั
Figure 15b. E-perpendicular apparent resistivity pseudosection calculated for two-dimensional model. Values in ohm-m. 
Table 1. Average strike directions determined at the Klamath Falls magnetotelluric stations (measured clockwise from true north)

\begin{tabular}{lcc}
\hline Station & Tensor Impedance Strike & Tipper Strike \\
\hline Parker & -13.1 & -28.6 \\
Keno & -2.9 & -52.6 \\
Klanath Falls & 17.2 & 57.1 \\
Yonna & 18.6 & -2.2 \\
Beatty & -18.0 & -81.0 \\
Bly & -18.2 & -5.5 \\
\hline
\end{tabular}

between the vertical and horizontal magnetic flelds, were used to choose which principal direction was parallel to strike (E-parallel or TE mode) and perpendicular to strike (E-perpendicular or TM mode). Figure 14 shows the pseudo-sections for both the observed E-parallel (Figure 14a) and E-perpendicular (F1gure 14b) sounding curves. Station 2A-77, within the Swan Lake Valley, was obtained by Geonomics, Inc. in 1977. It gives consistent apparent resistivities with respect to adjacent stations 7 and 8 .

The observed pseudo-sections were interpreted fointly in terms of a two-dimensional model which was obtained after numerous trial-and-error forward calculations helped $f i x$ the horizontal and vertical resistivity boundaries. In this endeavor, we benefitted from our previous experience in developing a 2-I model for the Swan Lake Valley region (Stark et al., 1979). After the boundaries were judged to be reasonable, resistivities within each block were optimized using a least-squares approach given by Jupp and Vozoff (1976). The resulting model is shown in Figure 13 and the calculated pseudosections for this model are shown In Figures $15 a$ and $b$. 
Comparing Figures $14 \mathrm{a}$ vs. $15 \mathrm{a}$, and $14 \mathrm{~b}$ vs. $15 \mathrm{~b}$, we see that the calculated psuedosections roughly match the observed data in general appearance, but the smaller details do not match. The problem here is that the area is not two-dimensional, as evidenced by the variability in geology and magnetotelluric strike directions. We also suspect that the area has been undersampled relative to the dimensions of lateral inhomogeneities. It is therefore problematical whether the additional effort needed to find better fits to the data would provide a commensurate improvement in subsurface information.

The gross resistivity structure indicated In Figure 13 agrees with contemporary ldeas about crustal electrical properties. The near-surface conductive formations, the thick mid-crustal resistive unit and the deep conductor have been commonly Interpreted from deep MT surveys (e.g. Stanley et a1., 1977) and predicted from laboratory studies (e.g. Brace, 1971). A similar picture emerges from the long-spacing dc resistivity measurements reported for the Klamath Basin area by Cantwell and Orange (1965). Our MT model for the Swan Lake Valley area (Stark et al., 1979) shows the same features. The geologic meaning of our reglonal MT model (Figure 14) is discussed below in the Geolog Ic Interpretation section.

\section{ELECTRICAL RESISTIVITY SURVE YS}

Figures 6 and 16 show the locations of the electrical resistivity surveys carried out on the east and west sides of Upper Klamath Lake, respectively. The data consist of the following surveys.

1. Twelve dipole-dipole lines and ten Schlumberger vertical electrical soundings were completed by Harding-Laws on Associates on the west side of the lake (Fig. 16) (Appendix 2, File 76-X-X-3). The dipoledipole lines were laid out with unit spacings. of $2000 \mathrm{ft}$ and measurements 


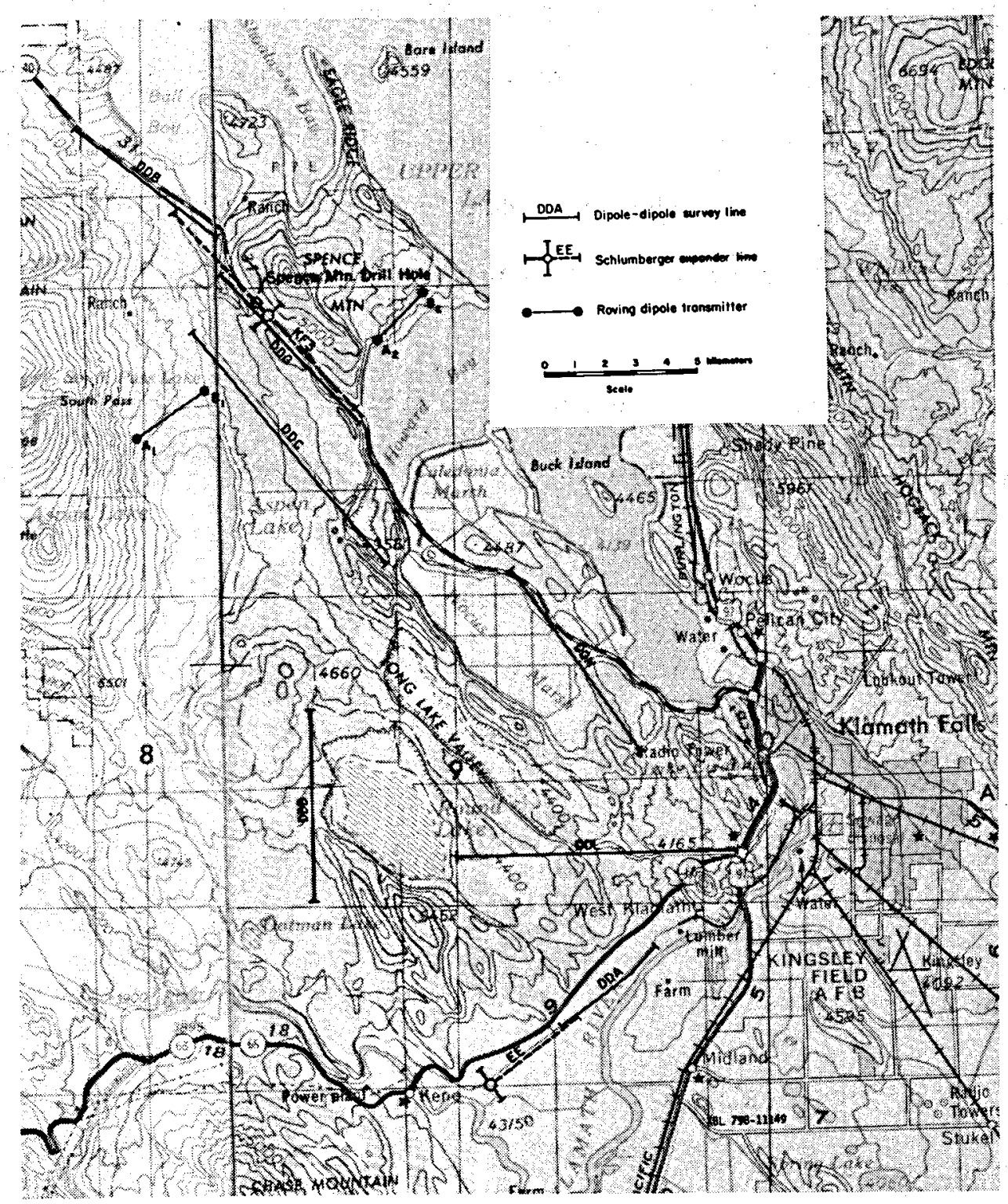

Figure 16. Location map of electrical resistivity surveys, west of Upper Klamath Lake. 
were made with $\mathrm{N}$ spacings of up to 5 or 6 . Total lengths of the lines ranged from 16,000 to $30,000 \mathrm{ft}$. The Schlumberger soundings were made by expanding the current electrodes in-line from $A B / 2=200 \mathrm{ft}$ out to $A B / 2=2000 \mathrm{ft}$, with potential electrode spacings MN/2 of 40 to 100 ft. For deeper penetration, the soundings were further expanded in the equatorial array with $A B / 2=1600 \mathrm{ft}, \mathrm{MN} / 2$ ranging from 100 to $1000 \mathrm{ft}$, and the equatorial distance $R$ ranging from $1000 \mathrm{ft}$ up to a maximum separation of 8000 to $12,000 \mathrm{ft}$. Although the equatorial soundings were not expanded bilaterally, some of the unilateral soundings coincided with dipole-dipole lines. This provides some insight into the effects of lateral resistivity changes.

2. A two-source roving dipole survey and three Schlumberger soundings were carried out by Geoterrex, Ltd., on the west side of the lake (Appendix 2, File 76-X-X-3). Geoterrex placed their 2.5-km transmitter bipoles near the northern end of Aspen Lake and along Squaw Point (F1g. 16). Data were taken at 110 potential dipole sites in directions both parallel and perpendicular to the transmitters. The locations of the Schlumberger soundings also appear in Figure 16. All of these were done in the equatorial configuration with $R$ spacings from 10 to $8000 \mathrm{~m}$. At the larger spacings the soundings were made bilaterally as a check for lateral resistivity variations. The equatorial soundings were Interpreted by using Dar Zarrouk curves (Zohdy, 1974) and an automatic Inversion scheme to yleld layered resistivity models.

3. A two-source roving dipole survey, 7 Schlumberger soundings, and 19 time-domain electromagnetic soundings were completed by Robert Furgerson (Appendix 2, File $76-X-X-3$ ) on the east side of the lake (Fig. 6). Furgerson's roving dipole survey was conducted with two orthogonal transmitter bipoles at each source location. The two sources were 
located near the northwestern corner of Swan Lake Valley, and in the Antelope Valley area, and each leg of the L-shaped configuration was over 1 mile long. This "rotating source" array allows some depth discrimation, because the depth of exploration is larger for a receiver located in an equatorial positon relative to the source than for a recelver positioned in-1ine, source-receiver distance being equal. Data were taken at about 100 L-shaped recelver sites, and a qualitative interpretation was made by the contractor.

Schlumberger soundings SEA $1,2,3$, and 4 were expanded out from the centers of the transmitter dipoles (Fig. 6). Roving dipole data from equatorial receivers could then be converted into bilateral Schlumberger equatorial data for these soundings, out to a maximum value of $R=27,000$ ft. SEA 5 was expanded in the standard Schlumberger array from $A B / 2=$ 100 to $2000 \mathrm{ft}$. The same procedure was used in SEA 6 and 7, but the soundings were further expanded equatorially out to $R$ values over 10,000 ft. SEA 7 was expanded bilaterally.

The standard Schlumberger portions of the soundings (out to $A B / 2=$ $2000 \mathrm{ft}$ ) were converted into layered-earth resistivity models by means of an inversion scheme. The bilateral portions of the soundings were not similar enough to allow one-dimensional interpretation. SEA 5 was interpreted by means of a graphical method which assumes a nearby dipping resistivity boundary. This was deemed necessary because of the proximity of the sounding to a mapped fault at the base of Naylox Mountain (Fig. 6). Furgerson also completed 19 time-domain EM soundings in the area and interpreted them by means of a complicated curve-matching scheme. The interpretation was based on a two-layered earth assumption, and resulted in an estimate of the resistivity of the half-space beneath the first layer at each site. 
Spence Mountain Area

We attempted a fairly extensive reinterpretation of the data from the west side of Klamath Lake, particularly those from the vicinity of Weyerhaeuser's 2000-ft test well near Spence Mountain (Figure 16).

The volcanic centers of the Mountain Lakes Wilderness lie west of the site; to the northeast warm springs occur at Eagle Point. One speculation was that heated water might be flowing down from the Mountain Lakes area and emerging at Eagle Point, and a drill hole near Spence Mountain was planned to test this hypothesis and to gain stratigraphic information. Before drilling, both Harding-Lawson (Appendix 2, File 74-2-12) and Geoterrex (Appendix 2, File 75-2-14) were contracted to carry out electrical surveys in this area. Harding-Lawson's dipole-dipole pseudosection DDG and Geoterrex's Schlumberger sounding KF3 are shown in Figures 17a and 18. In Figure 18 we have plotted only the data corresponding to $R$ spacings over $800 \mathrm{~m}$, even though data were taken at electrode spacings as small as $100 \mathrm{~m}$. Th1s was because we were primarily interested in modeling the deeper structure.

These data obviously suggest the presence of a conductive body at depth. Geoterrex interpreted sounding KF3 by means of a one-dimensional automatic inversion scheme. The most important feature of their final model is a sharp drop in resistivity from 1900 to $3.2 \mathrm{ohm}-\mathrm{m}$ at a depth of about $1500 \mathrm{ft}$. The calculated sounding curve for this model is incorporated In Figure 18.

Harding-Lawson's dipole-dipole line DDG overlaps Schlumberger sounding KF3, but they made no attempt at a quantitative interpretation of the dipole-dipole data. However, Furgerson (Appendix 2, File 76-X-X-3) 
a) Observed pseudosection

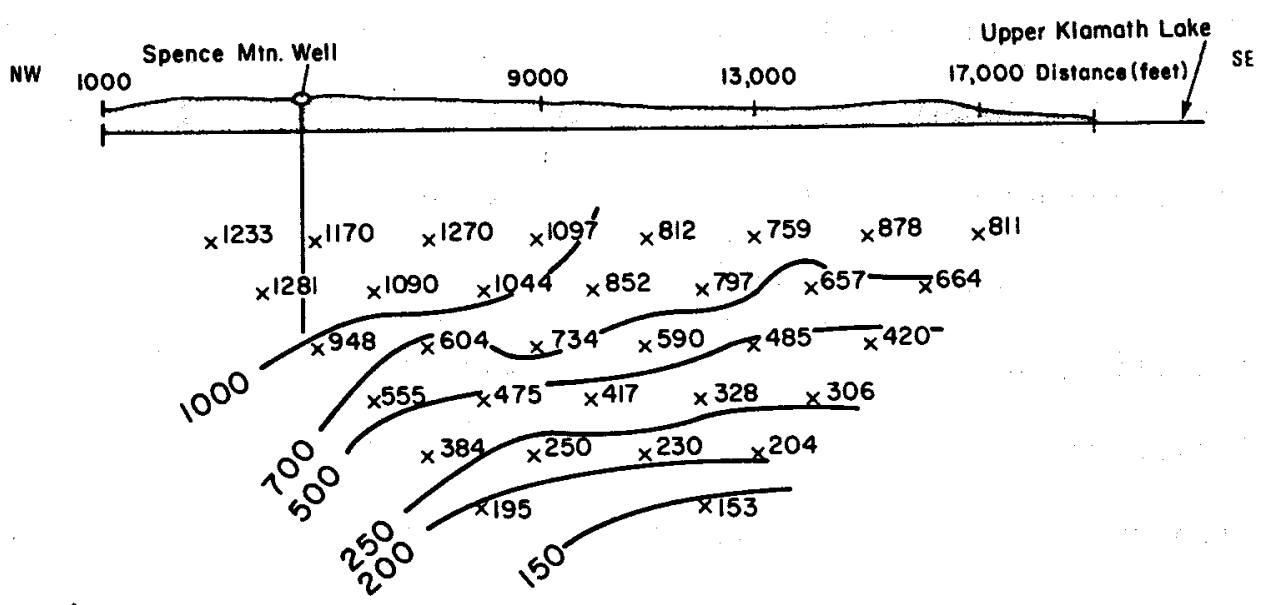

b) Calculated pseudosection

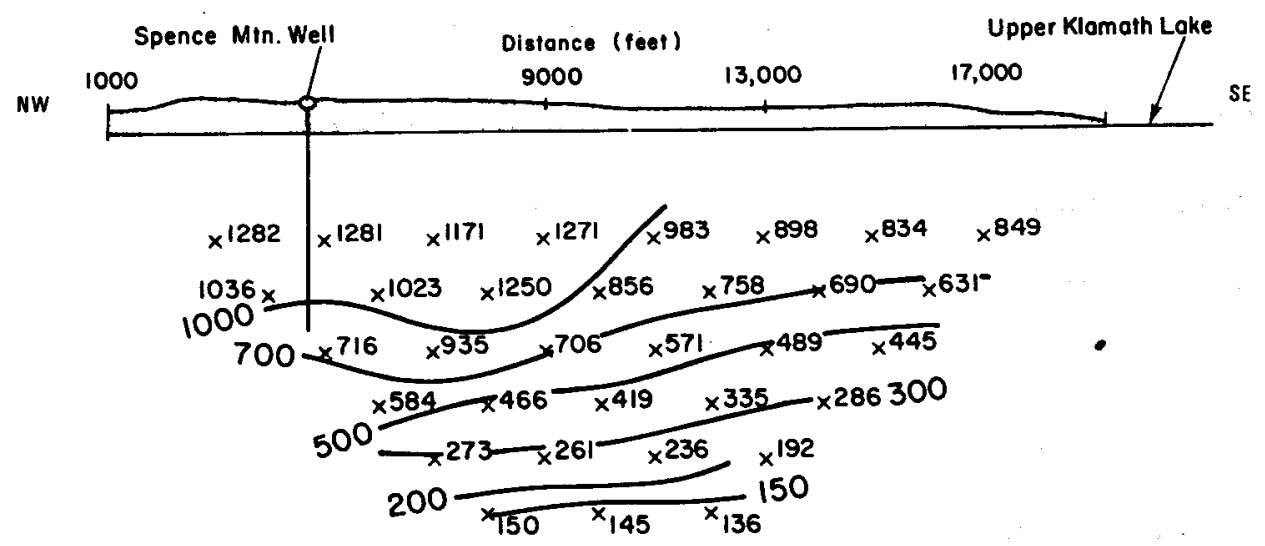

c) Model DDG

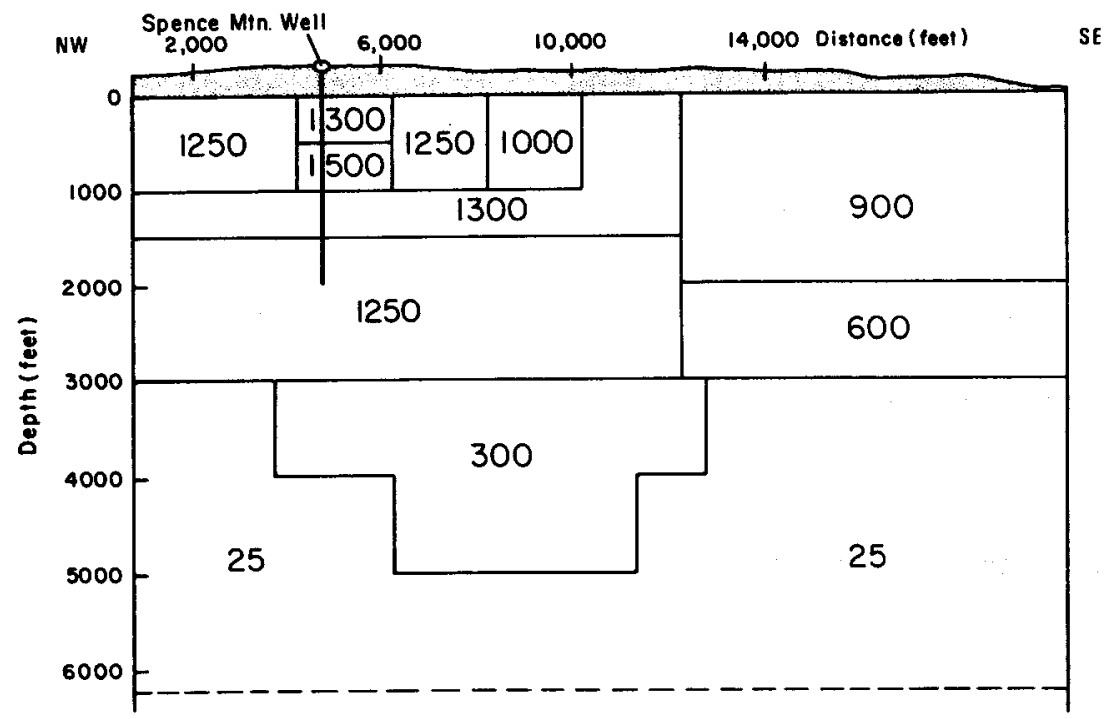

XBL $798-11452 A$

Figure 17. Dipole-dipole line DDG, values on ohm-m. 


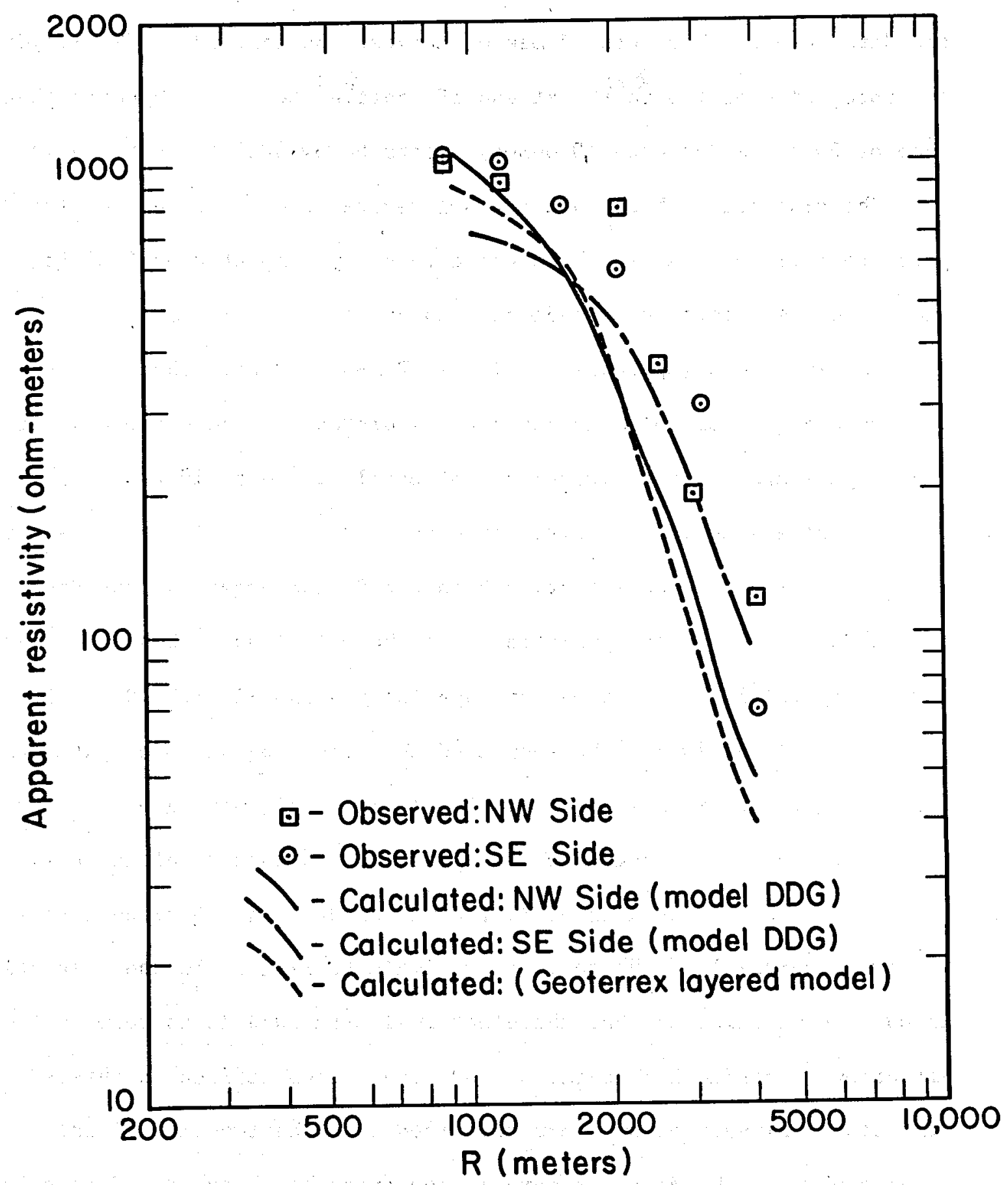

XBL 798-11148

Figure 18. Bilateral Schlumberger equatorial sounding KF3, with synthetic soundings for model DDG and Geoterrex model. 
later made a rough two-layer interpretation of DDG, by comparing parts of the data to published sets of master curves. He concluded, "Two-layer interpretation of the southeast end of profile DDG... suggests that a zone of $80 \mathrm{ohm}-\mathrm{m}$ (or even $10 \mathrm{ohm}-\mathrm{m}$ ) exists below 3000 to 4000 feet." The discrepancy between the two interpretations was not resolved prior to drilling, but the hole was eventually completed at $2000 \mathrm{ft}$, deep enough to test Geoterrex's shallower conductor.

The well logs (Appendix 2, File 76-X-X-3) indicate that the entire section consists of volcanic material saturated with cold fresh water. The temperature $\log$ was virtually isothermal at about $11^{\circ} \mathrm{C}$.

We reanalyzed the resisitivity data, arriving at a two-dimensional model (Fig. 17c), which satisfies both the Schlumberger and the dipoledipole data sets and is consistent with the well logs. This model was derived by trial and error use of modeling program RESIS2D (Dey, 1976; Dey and Morrison, 1977). We then used the same program to compute Schlumberger soundings for the dipole-dipole model, making only minor modifications in that model to satisfy both data sets simultaneously.

It should be noted, however, that lines DDG and KF 3 trend northwesterly, parallel to the regional geologic strike, while the assumption in our 2-D modeling is that the electrical structure is uniform in the direction perpendicular to the survey line. Thus we faced a threedimensional situation, and were surprised that the two-dimensional model could fit the data. Figure 17 compares the observed and calculated dipole-dipole pseudosections; the observed and calculated Schlumberger curves are presented in Figure 18.

A very important feature of the model is that the depth to the conductive horizon is 3000 to $5000 \mathrm{ft} ; 4000 \mathrm{ft}$ beneath the Spence Mountain drill 
site. This result is similar to Ferguson's two-layer interpretation. The 25 ohm-m resistivity value is not very well constrained by the data, and the true value could easily fall within the range of 5 to $25 \mathrm{ohm}-\mathrm{m}$. This unit may or may not be conductive enough, to indicate geothermal activity.

The Schlumberger data alone do not allow a unique interpretation. In Figure 18 we see that two radically different models produce equally good fits to the observed data. By simultaneously satisfying the dipoledipole data we were able to determine the depth to the conductive horizon much more accurately. We found that a dipole-dipole pseudosection calculated for Geoterrex's layered model was a poor fit to Harding-Lawson's data.

For this area we belleve that two-dimensional modeling was not necessary to establish a target depth." Furgerson's two-layer dipoledipole interpretation could have been used in conjunction with the Schlumberger data to estimate a depth of 3000 to $5000 \mathrm{ft}$ to the conductor. The resistivity $\log$ of the Spence Mountain hole is of poor quality and is at best a qualitative tool for gross lithologic distinctions. Furgerson's (Appendix 2, File 75-7-2-3) analysis of the log indicated that the wellbore penetrates thick resistive (hundreds and thousands of ohm-meters) formations alternating with thinner strata of more conductive material. The resistive zones appear to correspond to massive basalt flows in the lithologic log, while the conductive zones probably correspond to fractured basalt, scorla, and/or tuff. Unfortunately, it Is impossible to tell from the resistivity log whether the most conductive zones have resistivities on the order of ones, tens, or hundreds of ohm-meters. However, based on our specific-conductivity arguments we expect the lowest resistivities to be at least $70 \mathrm{ohm}-\mathrm{m}$, since all the 
water encountered in the well was cold.

Our model (Fig. 17a) shows the hole penetrating only resistive material (1000 to $1500 \mathrm{ohm}-\mathrm{m})$. This is roughly compatible with the resistivity $10 \mathrm{~g}$; the thin "conductive" zones of over $70 \mathrm{ohm}-\mathrm{m}$ In the $10 \mathrm{~g}$ would probably not be discerned in the surface resistivity data.

The exploration planners in charge of the Spence Mountain effort gathered a considerable amount of geological, geophysical, and geochemical Information about the west shore area before choosing their site. Unfortunately, as is often the case, legal and financlal considerations placed heavy constraints upon the location and depth of the hole. Shallow temperature surveys were not attempted because 1 was felt that the enormous regional groundwater flow would effectively mask the near-surface thermal gradient. For similar reasons, the planners chose not to run a full suite of well logs, and did not take core samples.

Geologic Interpretation of the Model DDG. The upper $300 \mathrm{ft}$ of the model (Fig. 17a) consists of blocks ranging in resistivity from 600 to $1500 \mathrm{ohm}-\mathrm{m}$. We see evidence for a lateral discontinuity between the 900 ohm-m block to the southeast and the $300 \mathrm{ohm}-\mathrm{m}$ material to the northwest. The discontinuity extends downward $3000 \mathrm{ft}$ to the conductive block below. The meaning of this break is uncertain; it may be merely a topographic effect from Spence Mountain. The fact that DDG trends parallel to strike makes intepretation of lateral discontinuties difficult.

The variation among resistivities on elther side of the break can probably be attributed to surface inhomogeneities, topographic effects, and actual resistivity contrasts among basalt flows.

The 300 ohm-m block may represent a thickening of the volcanic pile beneath Spence Mountain. Alternatively, we may be seeing the effects of 
current channeling through the lake as the dipoles approach the lakeshore to the northwest and southeast. If this were the case, the actual depth to the conductive block might be closer to $5000 \mathrm{ft}$ everywhere along the 11ne.

The cause of the low resistivity $(25 \mathrm{ohm}-\mathrm{m})$ unit is still open to question, as the well was not deep enough to test the anomaly. The high specific resistivity of the regional groundwater (see geochemistry section above) rules out cold water in fractured or porous rock as an explanation for the low. Therefore, we would expect to see conductive formations, such as tuffs and clays, possibly saturated with hot water, at this depth. Presumably, the large reglonal cold groundwater flow would mask any thermal gradient due to a hot-water body at a depth of $3000 \mathrm{ft}$ or more.

Other Data in the Spence Mountain Area. Dipole-dipole line DDC runs parallel to and $2 \mathrm{~km}$ southwest of DDG. Figure 19 presents our model for Iine DDC, and the observed vs. calculated pseudosections. This is a fairly rough fit, as we were mainly interested in understanding the gross features here. The model is similar to our model for DDG, but the resistivities in the upper $2000 \mathrm{ft}$ are somewhat lower, and the depth to the conductive zone slightly shallower (2000 to $5000 \mathrm{ft}$ ). This model also features a strong lateral resistivity break, at $20,000 \mathrm{ft}$ along the profile. This break corresponds to a short mapped fault (Fig. 5) which trends northeast, southeast side downthrown.

Northwest of Iine DDG lies dipole-dipole line DDB. For this we also attempted a rough fit to the observed data; the model and the observed and calculated data are shown in Figure 19. Presumably, the model represents dense basalt flows flanked by alluvium and unconsolidated sediments. The sedimentary formations appear to thicken to the northwest and the 


\section{a) Observed pseudosection}

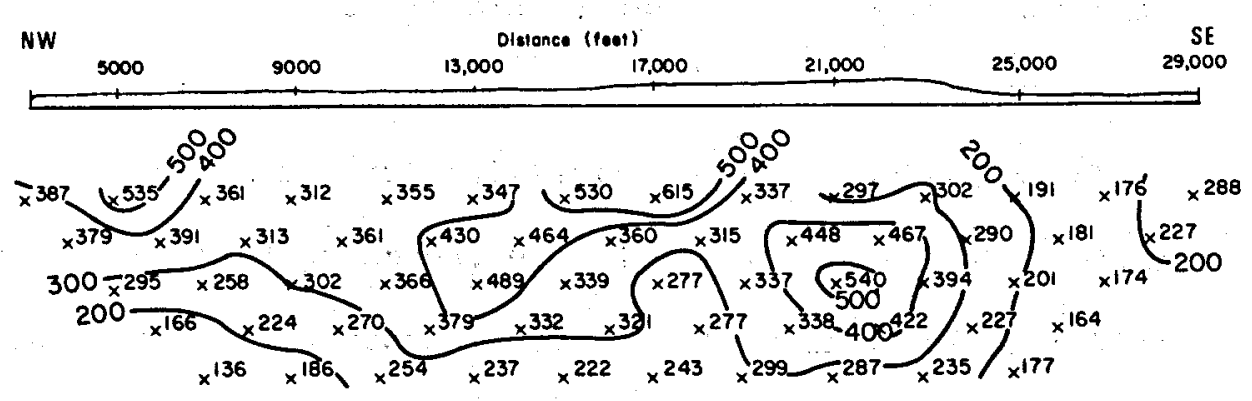

\section{b) Calculated pseudosection}

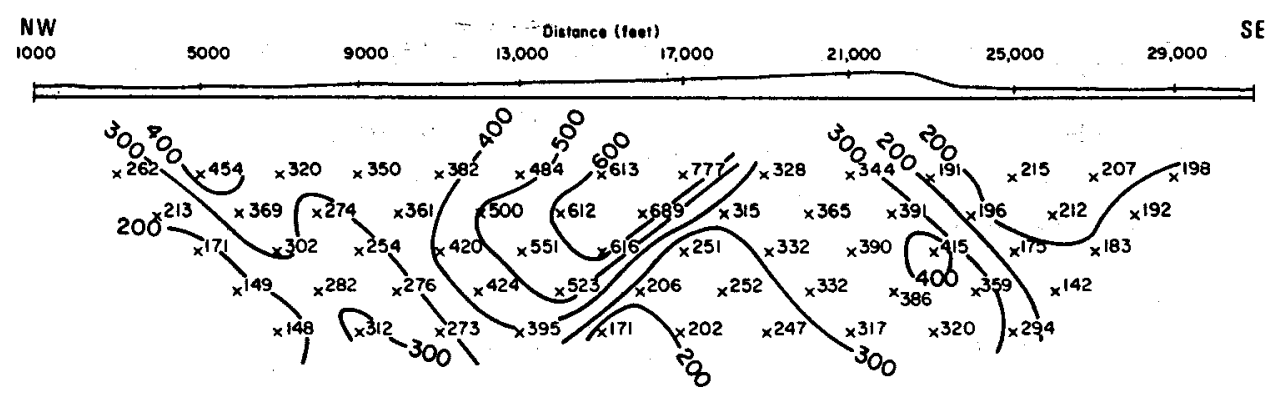

\section{c) Model DDC}

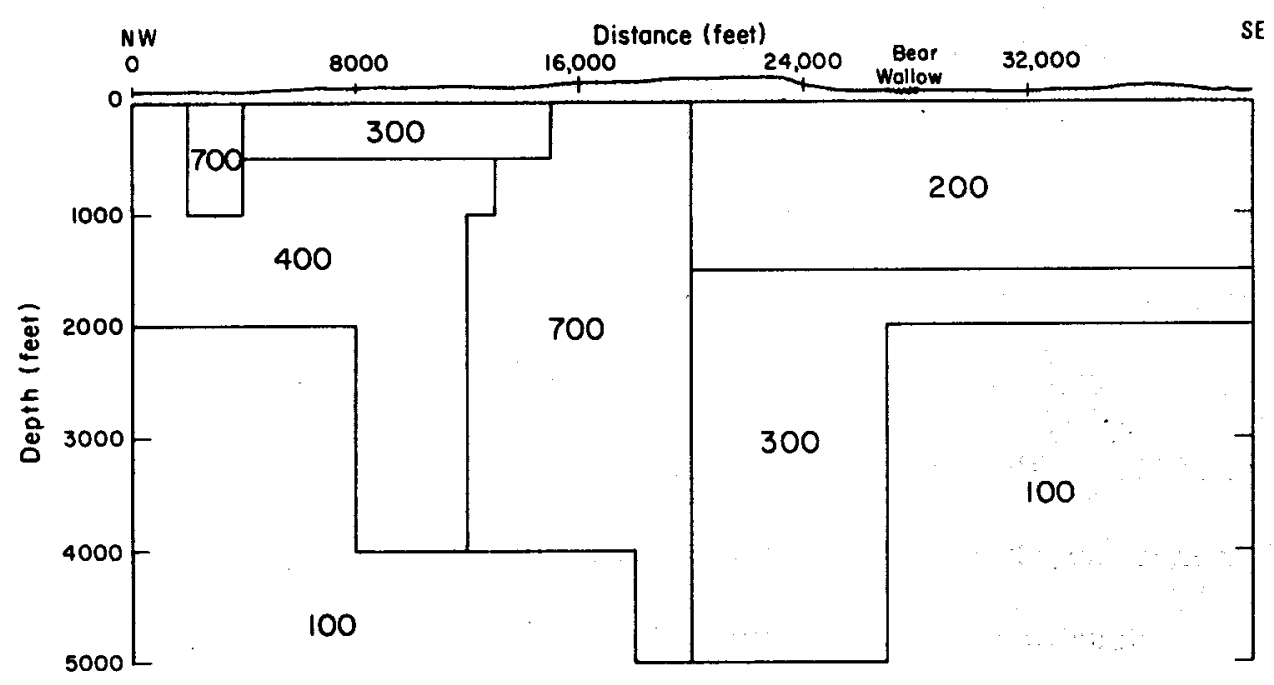

XBL $798-11467 A$

Figure 19. Dipole-dipole line DDG, values in ohm-m. 
a) Observed pseudosection

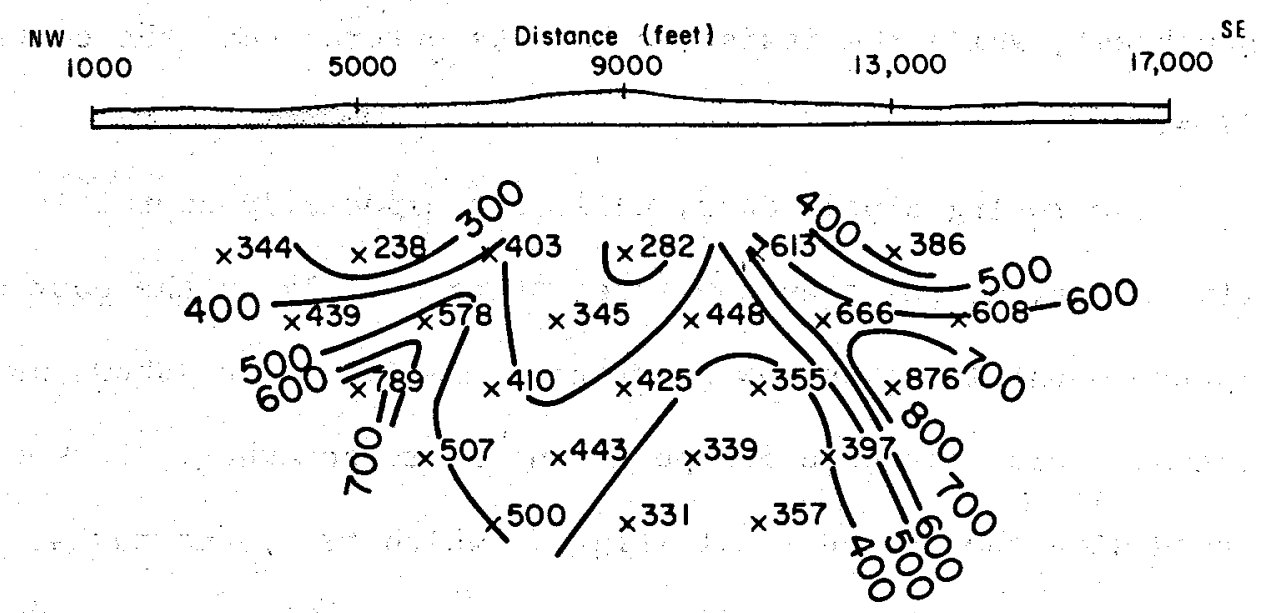

\section{b) Calculated pseudosection}

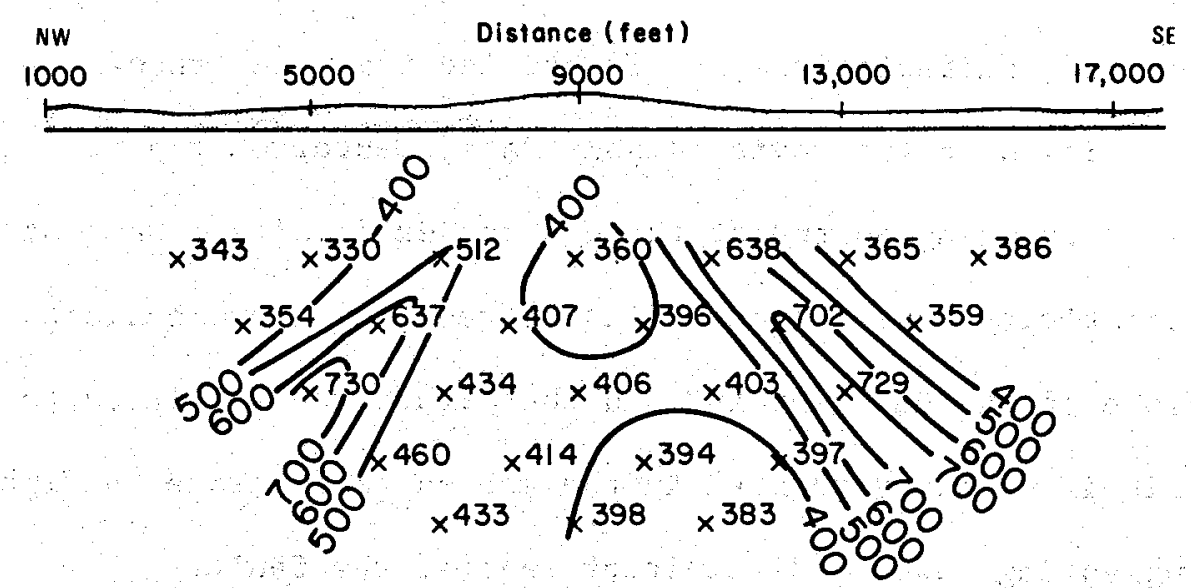

\section{c) Model DDB}

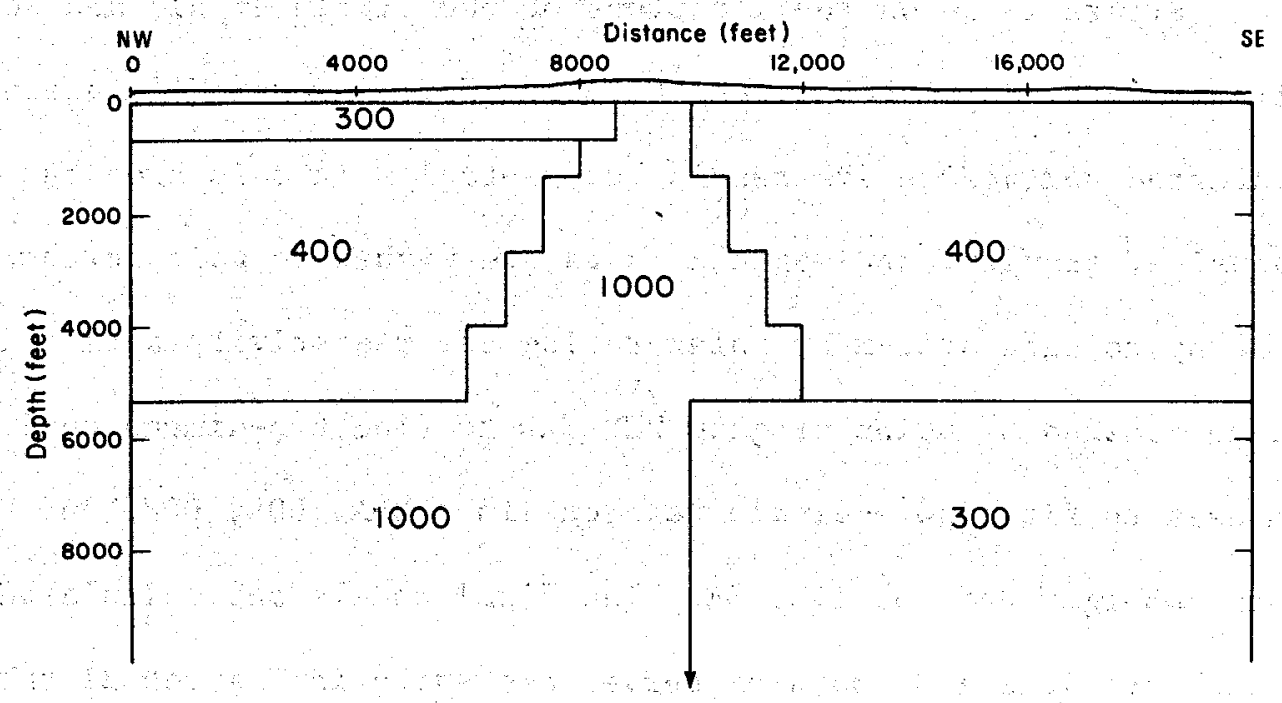

Figure 20. Dipole-dipole line DDB, values in ohm-m. 
southeast, while the resistive basalts outcrop near the center of the line.

The roving dipole data, while not espectally useful in a quantitative sense, do point up one interesting anomaly on the east slope of Spence Mountain. The low apparent resistivity zone shows up with both transmitters, although its position shifts somewhat. It seems to be assoclated with the mapped fault (Fig. 5) which trends northwest to the peak of Spence Mountain and bends north up to Shoalwater Bay. The anomaly may be indicative of hydrothermal circulation in the fault, although no surface manifestations are identified near the trace.

Based on the roving dipole data, Geoterrex reported a "conductive axis" trending northwest through the dri11 site. On most of the apparent resistivity maps the axis lies between the aforementioned low on the east slope of Spence lountain, and the higher resistivities to the west. The axis is probably related to the mapped fault trace on Highway 140 , suggesting lower resistivities east of the fault.

\section{Round Lake, Long Lake and Weyerhaeuser Mi11 Areas}

Figure 16 shows the locations of the dipole-dipole and Schlumberger lines in the Round Lake, Long Lake and Weyerhaeuser Mill areas. Having inferred northeasterly trending cross-faults in this area based on remote sensing, gravity, and magnetic data, we wished to gain further insight into the hydrologic system by interpreting the resistivity data. This was accomplished by using program RESIS2D to find two-dimensional resistivity models to fit dipole-dipole data on lines DDA, DDL, DDH, and DDD, and Schlumberger data on line EE. The final models and calculated and observed pseudosections and sounding curves are shown in Figures 21 through 25. 
Interpretation is complicated by three-dimensional structure along most of these lines. Lines $\mathrm{DDD}$ and $\mathrm{DDH}$ trend more or less parallel to the northwest geologic strike, while DDA and EE run perpendicular to strike but lie right next to a major northeast-trending discontinuity. In fact, only data from line DDL can be reasonably approximated by a two-dimensional model. Resistivity models for the other lines may be useful for general subsurface information.

It is Immediately apparent from inspection of the data and the models that most of the rocks in this area have lower resistivities than those the Spence Mountain area. Espectally interesting are the conductive zones (on the order of $10 \mathrm{ohm}-\mathrm{m}$ ) at depths of 1500 to $5000 \mathrm{ft}$ in these models. None of these data show any evidence of resistive basement.

Model DDA, shown in Figure 2lc, was designed to fit both dipoledipole data along Ine DDA and Schlumberger equatorial data on line EE. Figures $21 \mathrm{a}$ and $21 \mathrm{~b}$ show the observed and calculated data sets. The model contains several blocks of intermediate resistivity material (25 to $90 \mathrm{ohm}-\mathrm{m}$ ) extending from the surface to a $7 \mathrm{ohm}-\mathrm{m}$ unit at a depth of 3500 to $5000 \mathrm{ft}$. The $7 \mathrm{ohm}-\mathrm{m}$ untt is displaced along two discontinuties, resulting in a shallower depth to its top on the northeast end of the line. Also interesting is the 5 ohm-m block which comes up to a depth of $1500 \mathrm{ft}$. This may represent fluid leakage from the deeper $7 \mathrm{ohm}-\mathrm{m}$ undt.

The fit of this model to the Schlumberger equatorial data is shown in Figure 22. As previously noted, the line parallels nearby mountains, which undoubtedly introduces sufficient three-dimensional effects to place our two-dimensional interpretation in question. Presumably, the mountains are more resistive than the valley sediments, and current 
a) Observed pseudosection

\begin{tabular}{ccccc} 
SW & $\begin{array}{c}\text { Distance (foet) } \\
11,000\end{array}$ & 15,000 & 19,000 & NE \\
3000 & 2000 & 1100 & 19 \\
\hline
\end{tabular}

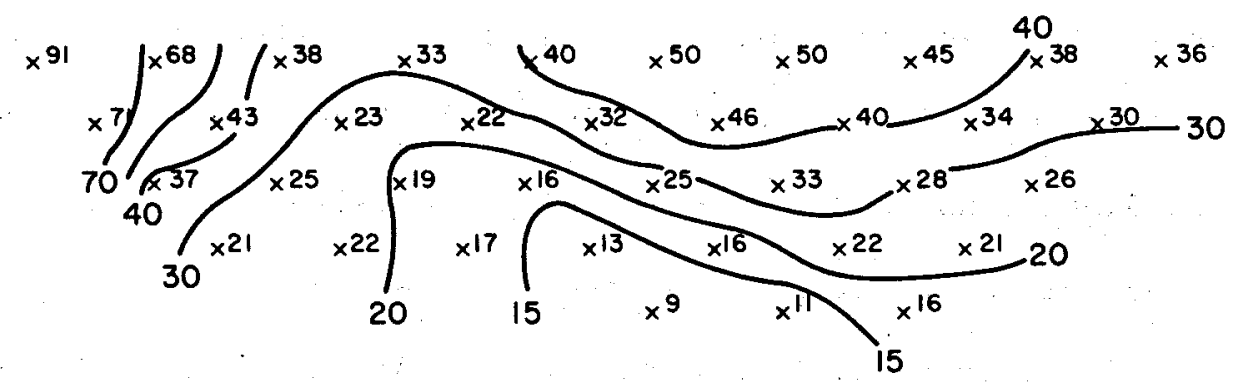

b) Calculated pseudosection
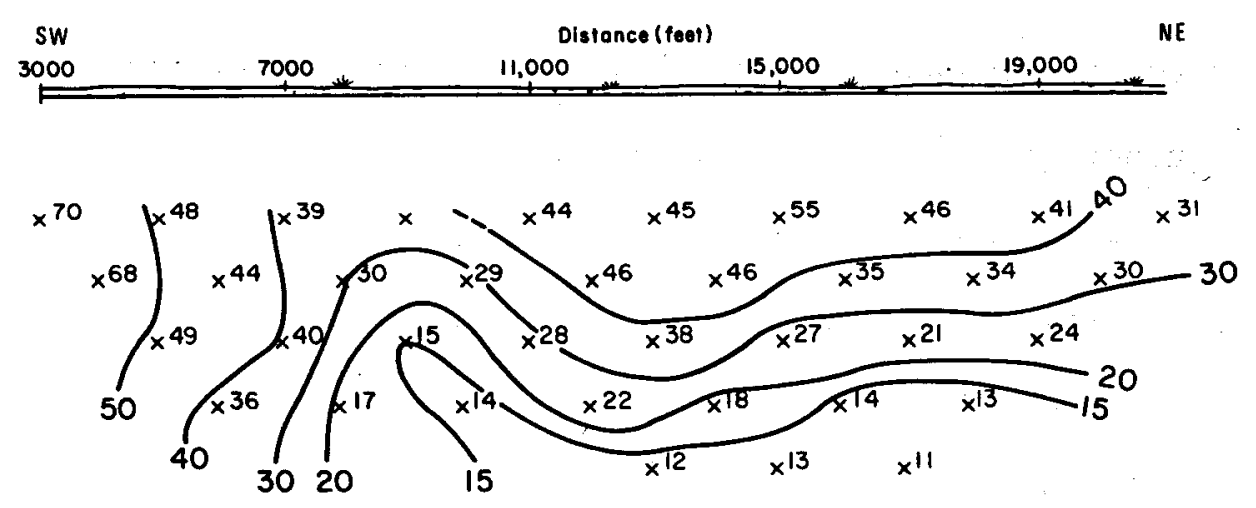

\section{c) Model DDA}

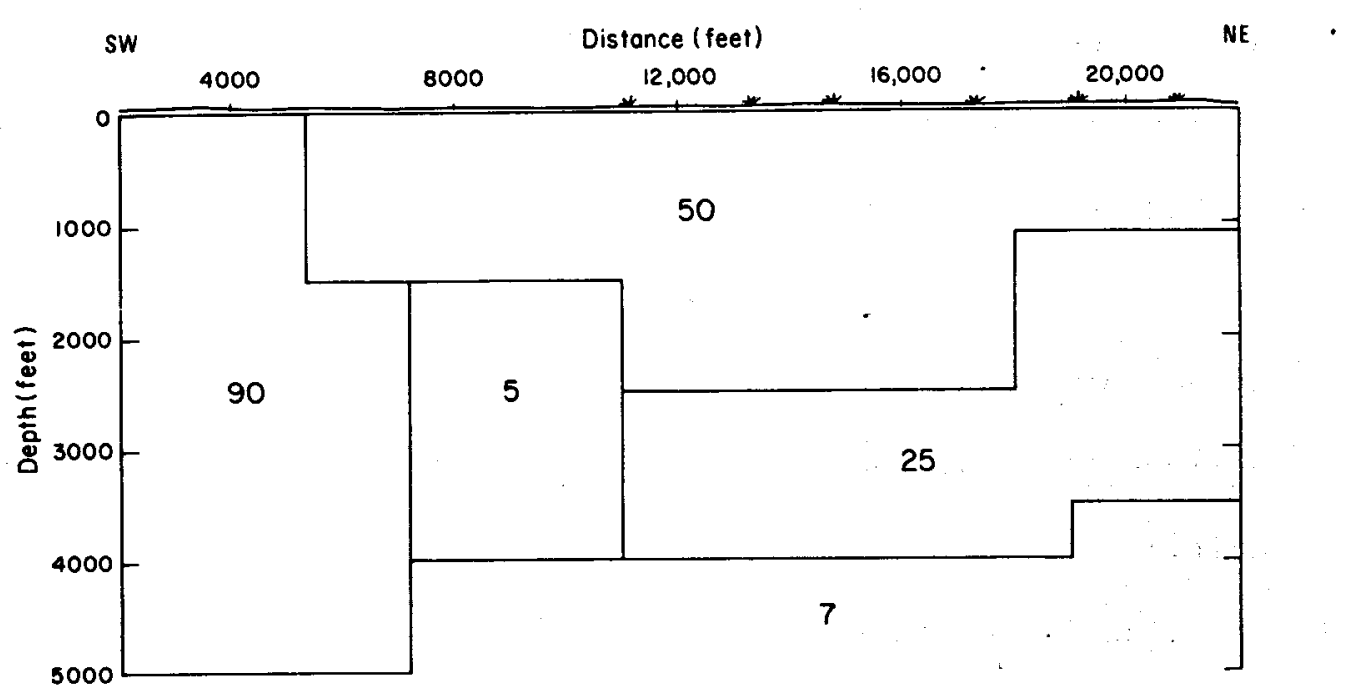

$X B L 798-11470 A$

Figure 21. Dipole-dipole line DDA, values in ohm-m. 


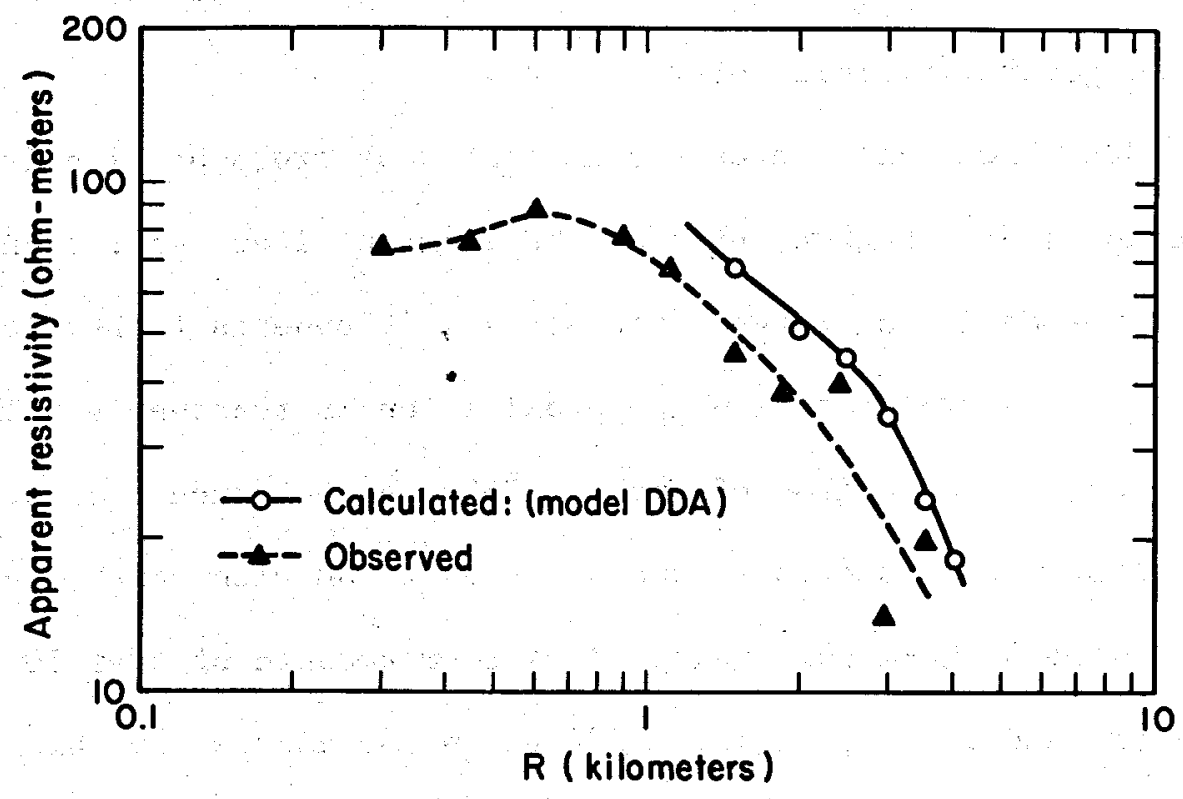

XBL $798-11473$

Figure 22. Schlumberger equatorial sounding EG, and calculated sounding for model DDA. 
would tend to concentrate in the valley at larger electrode spacings. This means that the measured apparent resistivities are higher than would be found for a true two-dimensional earth. Consequently, we suspect that the true resistivities of the deeper blocks are even lower than shown in Figure 21c. At any rate, the simultaneous fitting of both data sets supports the general validity of the model.

Model DDL (Fig. 23a) represents an east-west cross-section from the edge of Round Lake to Highway 66 near the Klamath River. Although the line is not perpendicular to geologic strike, it appears to be close enough so that the two-dimenstonal approximation is reasonable. The fit is fairly good, as comparison of Figures $23 b$ and $23 c$ demonstrates. The apparent resistivities decrease toward the east and with depth; this is expressed in the $5 \mathrm{ohm}-\mathrm{m}$ unit which rises from a depth of over 10,000 ft at the western end of the model to $1300 \mathrm{ft}$ in the east. In this respect it resembles Model DDA except for the higher resistivities at the western end.

Dipole-dipole lines DDD (FIg. 24) and DDH (Fig. 25) show similar features to DDA and DDL. Again, the models require deep conductive rocks that extend below the depth of resolution. The top of this conductor is found at shallower depths beneath valley areas, similar to models DDA and DDL. On DDH and DDD, however, we have no way of assessing the validity of the two-dimensional model; the lines are almost parallel to geologic strike, and there are no other resistivity data avallable to complement the dipole-dipole data. Therefore, we place less faith in these models and can use only the gross features for geologic interpretations discussed in the following section.

All of the electrical data in these areas indicate that the resis- 
a) Observed pseudosection
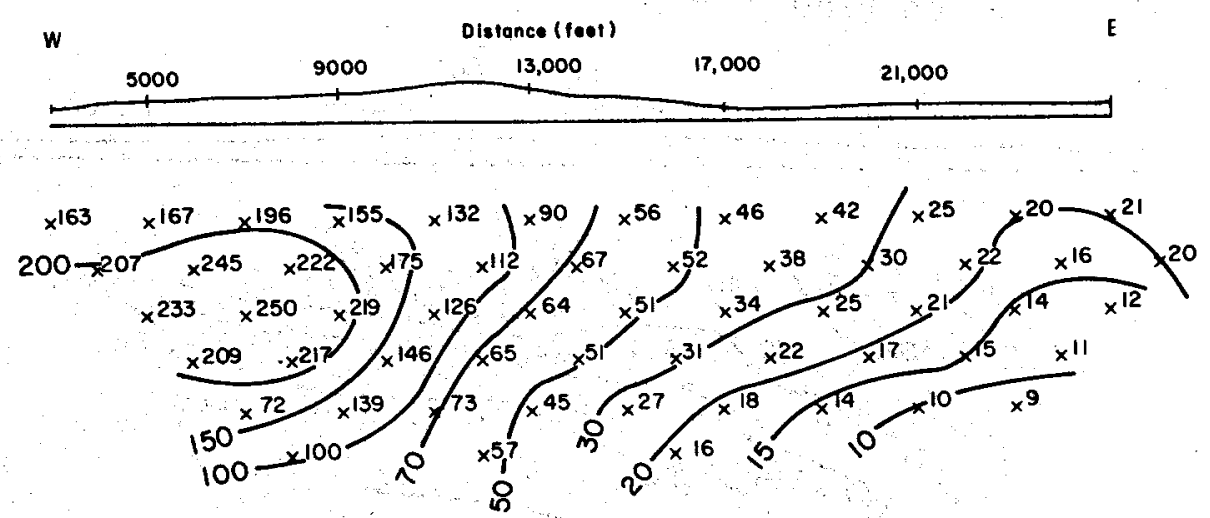

\section{b) Calculated pseudosection}
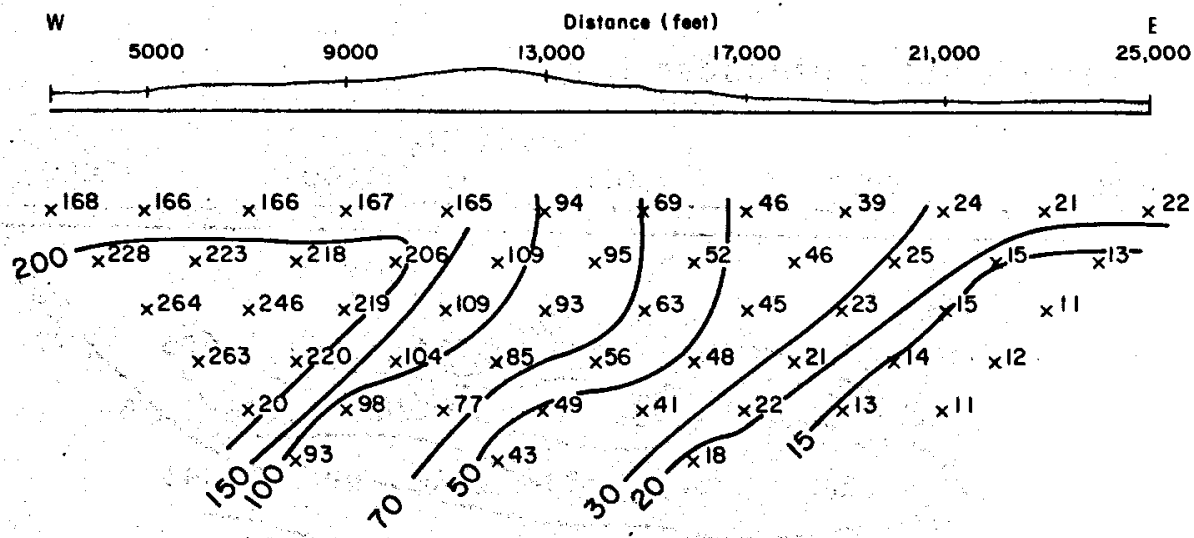

c) Model DDL

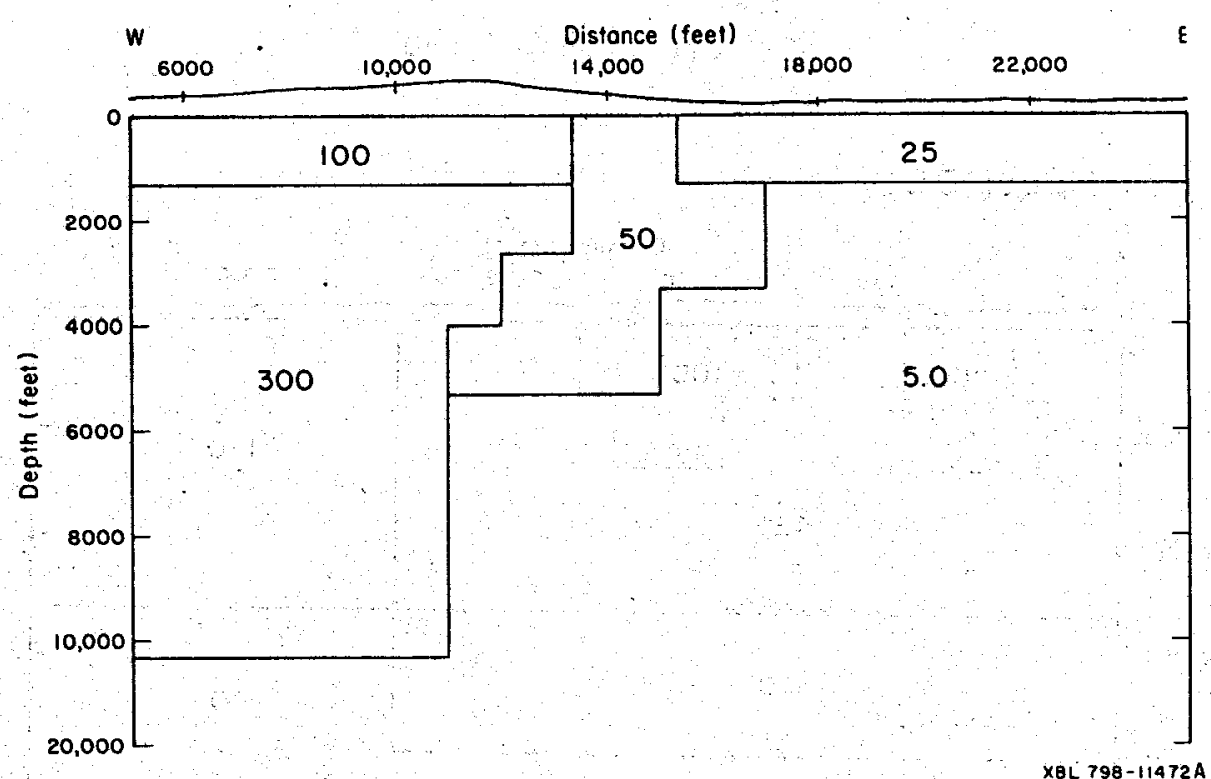

Figure 23. Dipole-dipole line DDL, values on ohm-m. 


\section{a) Observed pseudosection}
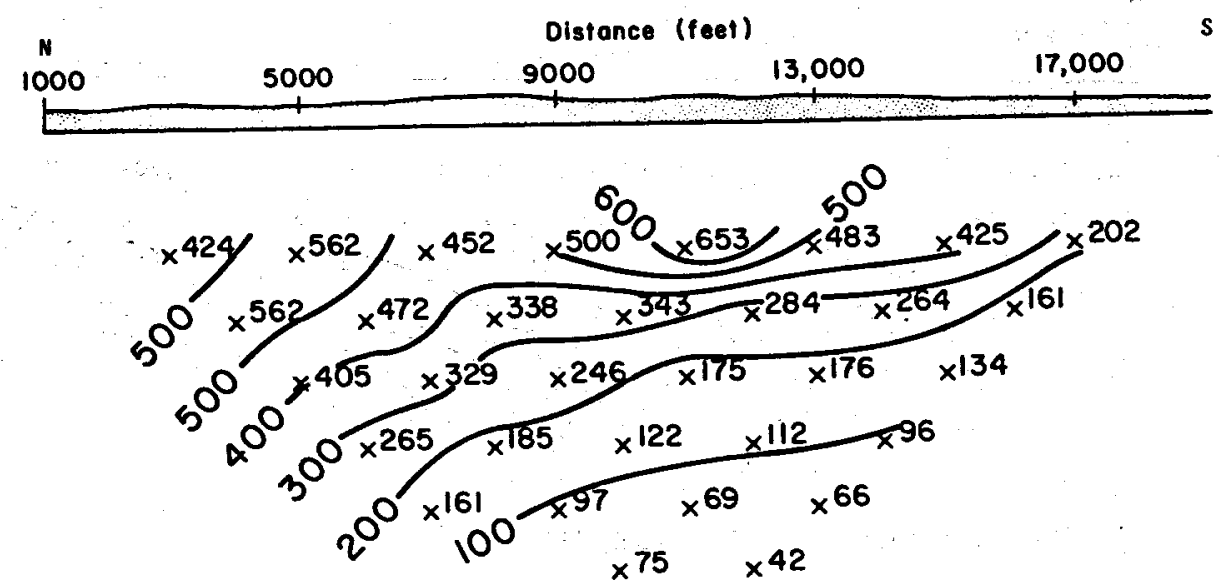

b) Calculated pseudosection

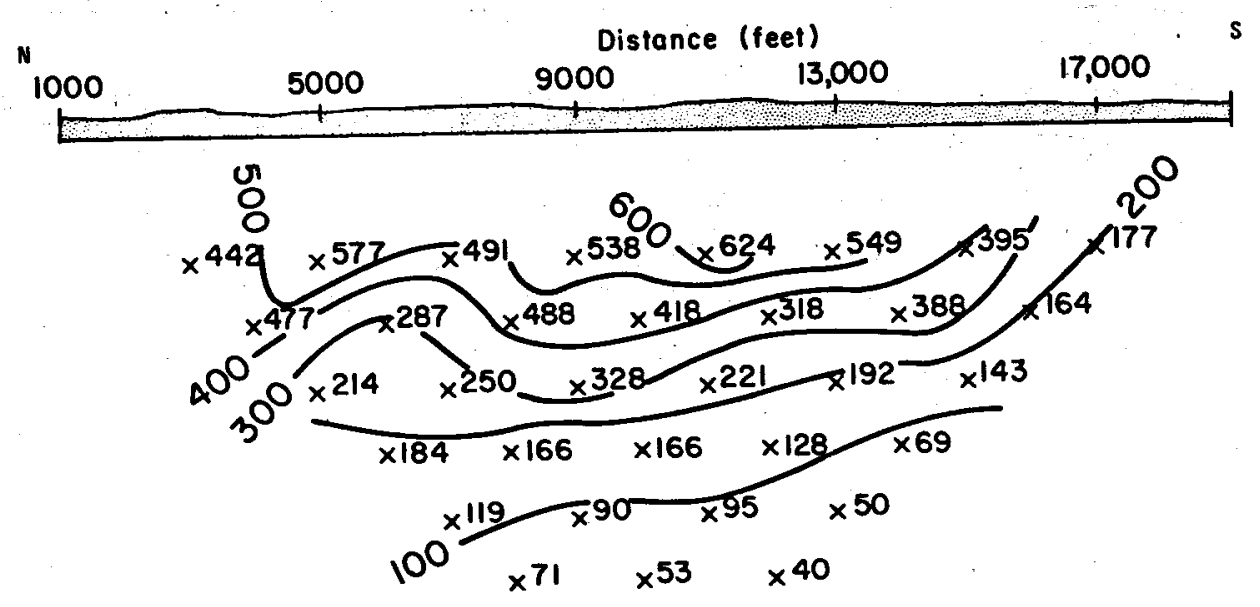

c) Model DDD

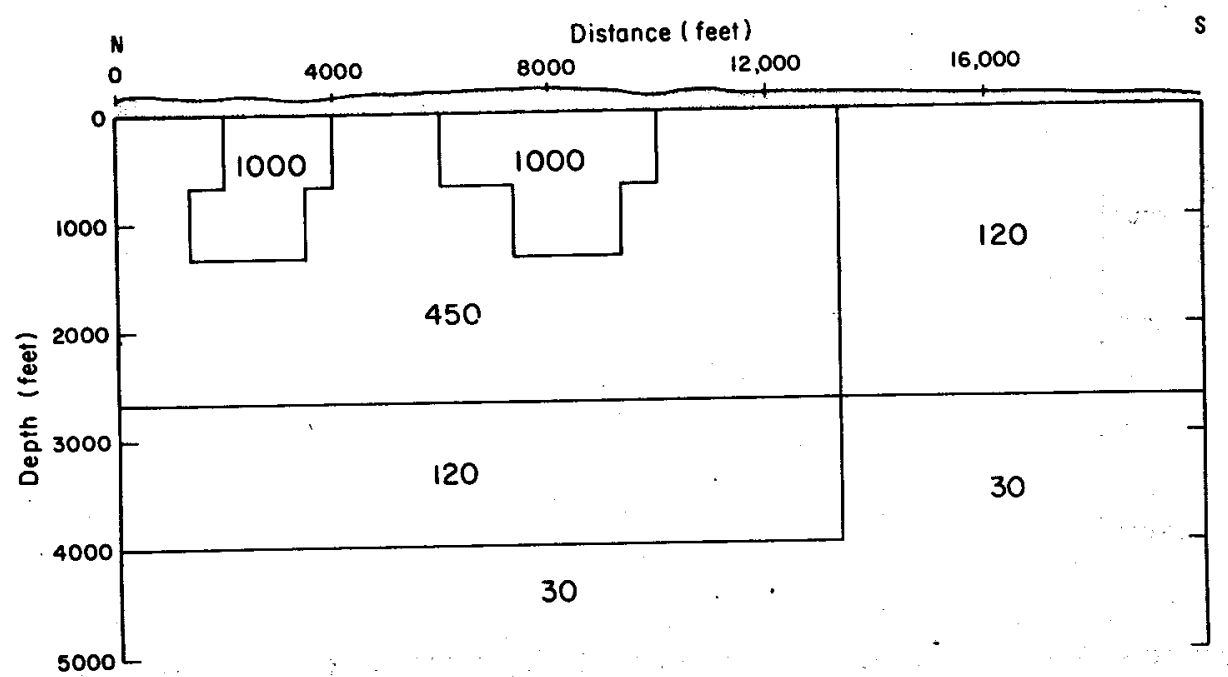

Figure 24. Dipole-dipole line DDD, values on ohm-m. 
a) Observed pseudosection

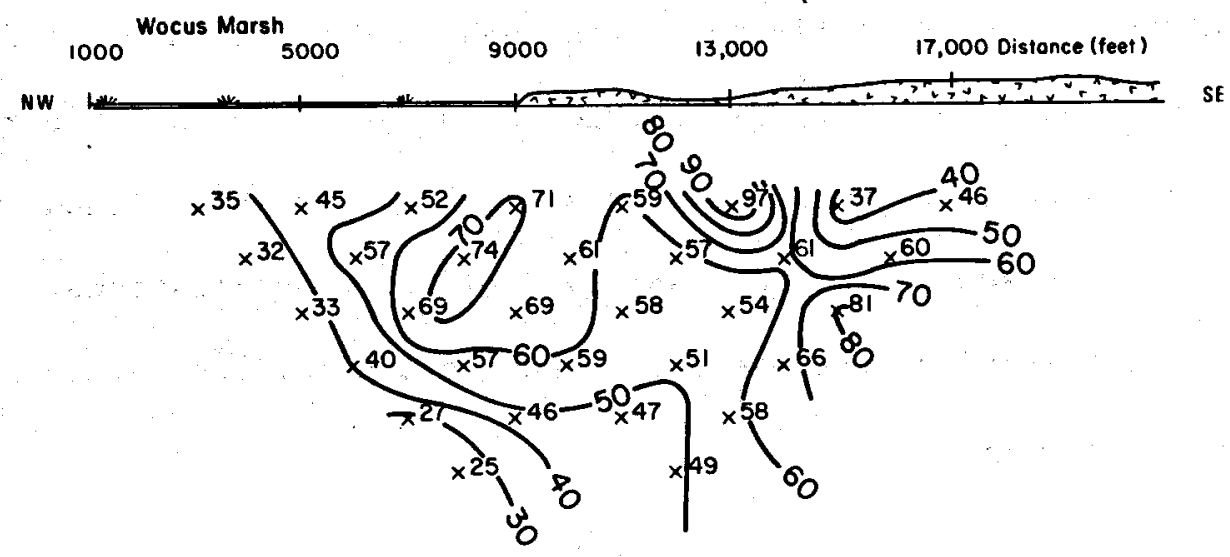

b) Calculated pseudosection

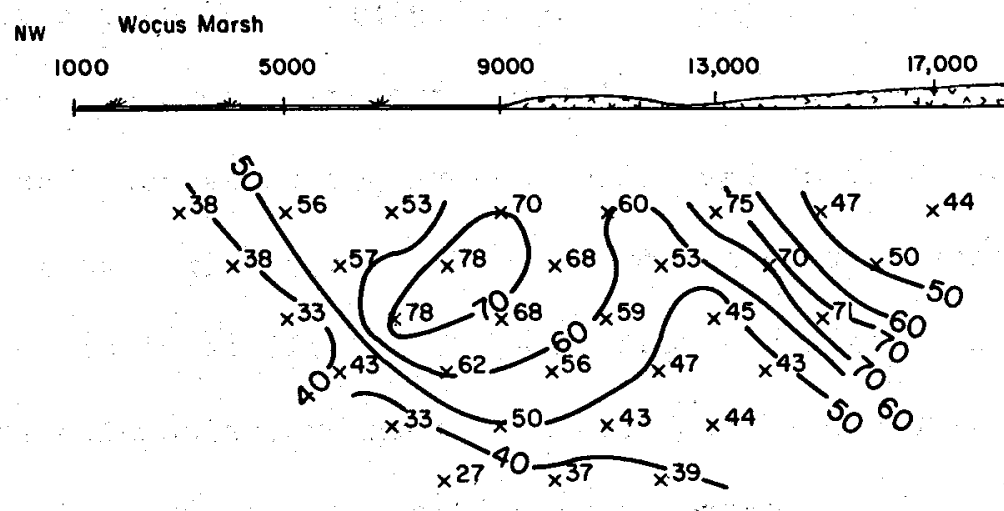

c) Model DDH

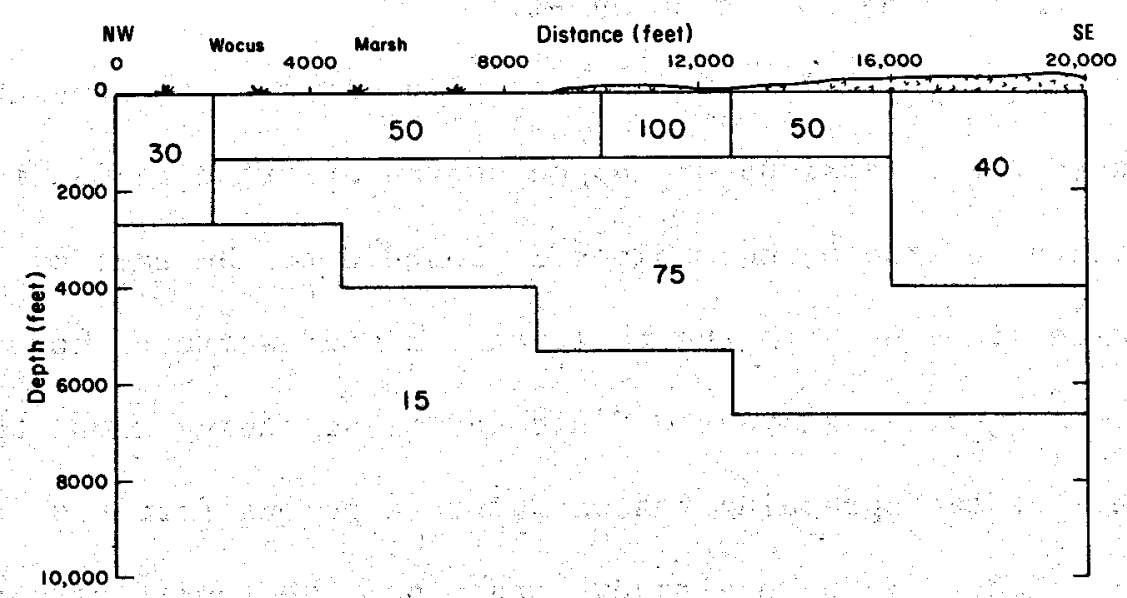

$\times 8 L 798-11471 A$

Figure 25. Dipole-dipole line DDH, values on ohn-m. 
tivity decreases with depth, but we have no basis for establishing a lower limit for the resistivity of the deep conductive unit. Therefore, most of the models were formulated "conservatively" in that the resistivity of the deep conductor was set as high as possible without violating constraints imposed by the data and by geologic considerations. The modeled resistivities of these deep conductors should therefore be considered upper limits.

Geologic Interpretation of Models DDA, DDL, DDD, and DDH. Table 2 presents the temperatures, specific resistivities, and depths measured in wells in this area. There is little correlation between these. three parameters. Most of the wells have temperatures somewhat above ambient groundwater, with a maximum of $27^{\circ} \mathrm{C}$ measured in a well near the quarry about 4 miles east of Round Lake. This well is close to the northeast-trending fault (Fig. 5), near its intersection with the fault along the northeast shore of Long Lake. All of the wells 11sted in Table 1 have specific resistivities above $20 \mathrm{ohm}-\mathrm{m}$, with most of the values falling between 30 and 50 ohm-m.

Hodel DDA (Fig. 2la) contains lateral discontinuities which may correspond to the extensions of mapped northwest-trending faults (Fig. 5). For Instance, the 5 ohm-m block is bounded to the east by a discontinulty which lines up with the fault on the southwestern shore of Round Lake. This suggests that heated fluld may be ascending along this fault zone, perhaps spreading westward into a porous formation to form the $5 \mathrm{ohm}-\mathrm{m}$ block. We have already noted that the resistivity of the local groundwater as measured in wells is substantially higher than 5 ohm $-\mathrm{m}$, so this block could not be saturated with cold groundwater. The block's shape seems to rule out conductive clays or tuffs as an explanation; these materials are usually found stratified rather than in blocks. 
Table 2. Temperatures, specific resistivities and depths of wells in the Lumber Mill area.

\begin{tabular}{ccc} 
Temperature & $\begin{array}{c}\rho_{\text {spec }} \\
\left(\text { at } 25^{\circ} \mathrm{C}\right.\end{array}$ & Depth \\
\hline$\left.{ }^{\circ} \mathrm{C}\right)$ & In ohm-m) & (m) \\
\hline 13 & 27.0 & 103 \\
16 & 40.0 & $?$ \\
15 & 40.8 & 240 \\
18 & 45.5 & 286 \\
Co1d & 37.0 & 227 \\
14 & 42.6 & 395 \\
20 & 45.5 & Spring \\
16 & 30.2 & 168 \\
27 & 33.3 & 765 \\
21 & 50.0 & 545 \\
22 & 35.7 & 286 \\
19 & 38.5 & 250 \\
12 & 32.8 & 120 \\
\hline
\end{tabular}

Note: After Sammel, 1976 
The near-surface lateral changes in resistivity. probably reflect variations in groundwater resistivity. One might expect relatively conductive marsh water in the $50 \mathrm{ohm}-\mathrm{m}$ block and cleaner, less conductive mountain water in the $90 \mathrm{ohm}-\mathrm{m}$ block.

The deep $7 \mathrm{ohm}-\mathrm{m}$ conductor is more difficult to understand. Furgerson (Appendix 2, File 76-X-X-3) speculated that it may reflect a regional trend of decreasing resistivity due to saline groundwater in the marshes to the southeast. Although we find no evidence for such conductive broundwater in the local wells (see Table 2), none of these wells is deeper than $800 \mathrm{ft}$, so we have no information on the groundwater characteristics in the deep conductive material. Deeper electrical methods, such as nagnetotellurics, could better define the shape and depth extent of this material.

Model DDL (Figure 23a) also terminates at depth in a conductive (5 ohm-m) half space. In this case the resistive overburden thins dramatically from the mountains in the west to the valley in the east. The lateral discontinuities seem clearly related to the mapped northwesttrending faults bounding Long Lake Valley. The $25 \mathrm{ohm}-\mathrm{m}$ unit may represent leakage of conductive fluid along these faults; the warm well $\left(27^{\circ} \mathrm{C}\right)$ at the quarry is located at about $18,000 \mathrm{ft}$ along the survey 1ine. The trace of the inferred northeast-trending fault (discussed in the reology section and shown in Fig. 5) crosses Line DDL and intersects one of the Long Lake faults near this well. Although it is one of the deeper we11s in the immediate area $(765 \mathrm{ft})$, it is not deep enough to penetrate the 5 ohm-m unit in model VDL, which lies at a depth of $1300 \mathrm{ft}$. This might be a yood location for an intermediate-depth hole to investigate the conductive material.

Models DDD (Fig. 24a) and DDH (Fig. 25a) show the same gross char- 
Models DDD (FIg. 24a) and DDH (FIg. 25a) show the same gross characteristics; each is underlain by a conductive half-space, similar to that found for DDA and DDL. These conductors are fairly deep, at least $2500 \mathrm{ft}$, and may not be as conductive as those beneath Iines DDA and DDL. Moreover, the two-dimensional assumption is especially weak for line DDH and DDD as we discussed above.

The nature of the deep conductive zones seen in all of the electrical data is an important unresolved question. As we noted above, the resistivities assigned to these zones in the models are essentially upper limfts; true resistivities may be $5 \mathrm{ohm}-\mathrm{m}$ or less, and the zones may all represent the same formation. However, it is difficult to imagine a common geologic formation underlying all these areas, particularly because the conductive horlzons consistently appear at shallower depths in view of the fact that the conductive horlzons consistently appear at shallower depths beneath the valleys than beneath the mountains. Another possible explanation for the conductive zones is that hot water rising along fault conduits, has spread laterally into deep fractured basalt flows or porous tuffs beneath mountainous areas and leaked laterally at the base of the sedimentary section under the valleys. If this is the case, we could have an enormous volume of hot water stored in the west shore area, from Spence Mountain southward to the Klamath River. To our knowledge, there are no wells in the west shore area deep enough to test these hypotheses. Two target areas could be drilled in the future. One is southwest of the pulp mill, where the 5 ohm-m block in model DDA could be explored at a depth of 1500 to $2000 \mathrm{ft}$. Another good location is near the quarry along line DDL. The conductive zone here should be found below $1300 \mathrm{ft}$. This site seems promising because of its proximity to the northeast-trending fault and to the $27^{\circ} \mathrm{C}$ well. Both 
sites are within a few miles of the mill; if the water is warm but not hot enough for power generation, then perhaps it can be used directly in the mill.

\section{Whiteline Reservoli Area}

Figure 6 presents the locations of roving dipole, Schlumberger, and EM surveys in the Whiteline Reservoir area. On the basis of these surveys, Furgerson (Appendix 2, File 76-X-X-3) concluded that there were no strong resistivity anomalies indicative of geothermal activity in the survey area. He did find that the fault along the southwestern slope of Naylox and Hogback Mountains has a strong effect on the resistivity structure, with much lower apparent resistivities measured by the roving dipole method southwest of the fault. A typical roving dipole apparent resistivity contour map is reproduced in Figure 26; the Plum Valley low shows up clearly. However, his EM interpretation indicated that the subsurface resistivity was at least 35 ohm-m, not conductive enough to warrant further exploration.

Furgerson also completed a Schlumberger expander sounding, SEA 5, out to $\mathrm{AB} / 2=2000 \mathrm{ft}$ southwest of the Naylox Mountain fault in Plum Valley (Fig. 6). The apparent resistivity curve he obtained (reproduced in Fig. 27 and labeled "Observed Curve") appears to contradict the EM interpretation; his two-layer interpretation indicates $15 \mathrm{ohm}-\mathrm{m}$ material down to $325 \mathrm{ft}$, with a resistive basement of at least $225 \mathrm{ohm}-\mathrm{m}$ extending to at least $2000 \mathrm{ft}$. Furgerson went one step further in his interpretation of this sounding; he applied a graphical method to compensate for the effect of the nearby fault, and the higher resistivity material beyond it.: He assumed that the fault dips $60^{\circ}$ and trends parallel to the sounding line, and that the earth northeast of the fault is a quarterspace of infinite reistivity. This allowed him to construct a sounding 


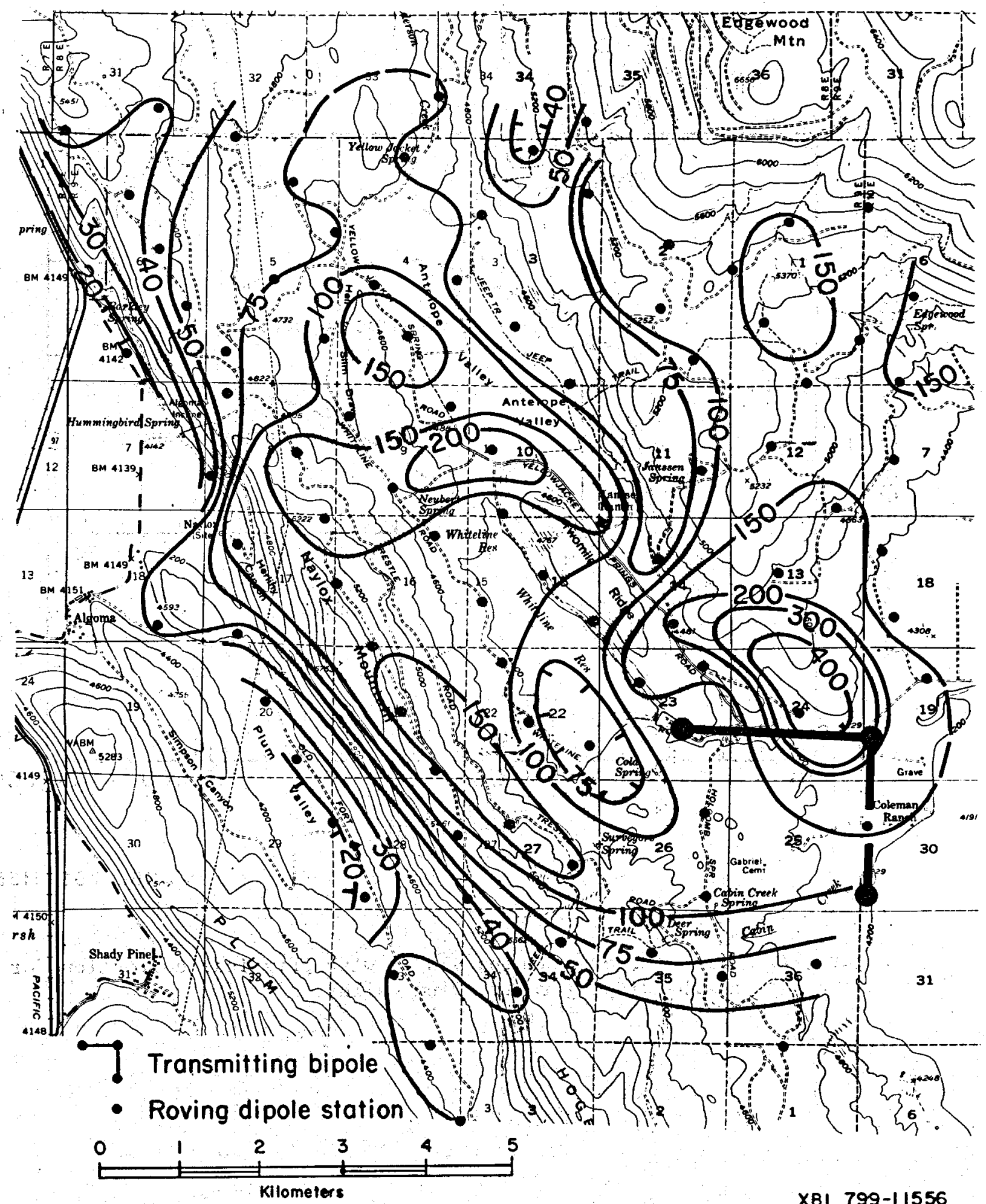

Figure 26. Average rotated apparent resistivity in ohm-m from Source 1, Whiteline Reservoir roving dipole survey. 


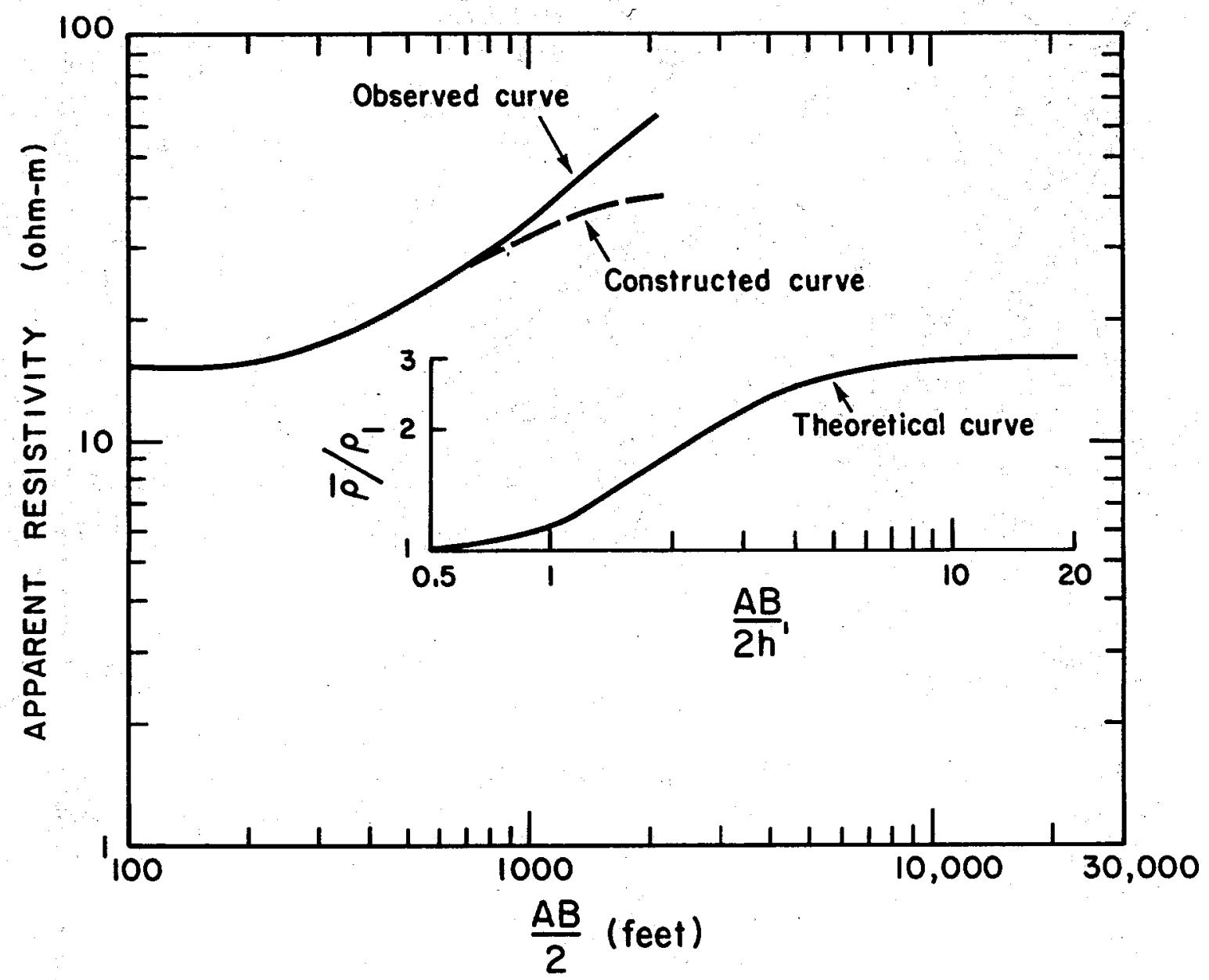

XBL $799-11553$

Figure 27. Schlumberger sounding SEA 5, with graphical correction for nearby dipping fault, Plum Valley. 
curve with the effect of the fault "subtracted out." In Figure 27 we have reproduced the theoretical curve for a sounding next to the dipping fault and the curve constructed by subtracting out the theoretical curve. Furgerson interpreted the constructed curve to yield a three-layer model quite different from his original two-layer model. The three layers have resistivities of 15,72 , and $36 \mathrm{ohm}-\mathrm{m}$ (from top to bottom). The top layer is $300 \mathrm{ft}$ thick and the middle layer is $600 \mathrm{ft}$ thick.

This procedure interprets the sounding without resorting to twodimensional computer modeling, but it is difficult to understand why the constructed curve was interpreted as a three-layer curve. We find that the constructed curve is a classic two-layer curve with a top-layer resistivity of $15 \mathrm{ohm}-\mathrm{m}$ underlain by a $40 \mathrm{ohm}-\mathrm{m}$ half-space.

Any interpretation of this curve must include a 15 ohm-m layer in the upper few hundred feet; this would seem to Invalidate Furgerson's two-layer EM Interpretation, which assumes a relatively resistive top 1ayer.

This leaves only the roving dipole low to rely on for deeper subsurface information. We did not attempt to model the roving dipole data. We do feel, however, that the Plum Valley anomaly should be Investigated further.

Another interesting roving dipole trend is found near the southeastern edge of the survey area, approaching the northwestern end of Meadow Lake Valley. Figure 26 shows a trend of decreasing apparent resistivity here. This area is of particular interest because it is adjacent to Holcomb Springs, where we found evidence (Stark et. a1. 1979) for a resistivity low based on magnetotelluric and other roving dipole data. 
Although we have not reinterpreted data in the Whiteline Reservoir area, we feel that the prospect was rejected prematurely. Ideally, roving dipole should be used as a reconnaissance technique, and more detalled methods should be employed to investigate specific anomalies. For Instance, the Plum Valley Schlumberger line could be expanded for deeper penetration. Another possibility would be to reinterpret the Plum Valley EM data. The multilayer time-domain problem can be solved with a computer program; perhaps a three-layer model would be useful. Synthesis and Geologic Interpretation of Resistivity Models

In this section, we shall first attempt to tie together our regional MT resistivity model with the dc resistivity models from the west and east shores of Upper Klamath Lake and with models for the Swan Lake Valley and Klamath Hills areas (Stark et al., 1979). The regional MT model (Figure 13) requires fairly conductive material (mostly about 18 ohm-m) material down to about $4 \mathrm{~km}$. Our dc resistivity models for the west shore area all terminate in conductive zones ( $<25 \mathrm{ohm}-\mathrm{m})$ at depth, but are quite resistive ( $>500 \mathrm{ohm}-\mathrm{m}$ in the mountainous areas) for the upper $0.5-3.0 \mathrm{~km}$. The Whiteline Reservoir data (see previous section) and the Swan Lake Valley models (Stark et al., 1979) both indicate moderately resistive material $(40-300 \mathrm{ohm}-\mathrm{m})$ in the upper few hundred meters, with more conductive rocks below. The Klamath Hills models indicate moderately conductive $(10-50 \mathrm{ohm}-\mathrm{m})$ to very conductive $(<10$ ohm-m) formations for the upper kilometer. These can all be reconciled with Figure 13 by noting that the highest frequency points obtained for the regional MT survey were $.1 \mathrm{~Hz}$, corresponding to a depth of exploration on the order of $5 \mathrm{~km}$. Therefore, any resistive formations shallower than $3 \mathrm{~km}$ would have little effect on these measurements; the conductive 
units found at depth would be much more important. We therefore conclude that the upper $4 \mathrm{~km}$ is characterized by decreasing resisitivity with depth. The only exceptional area occurs between stations $2 A-77$ and 8 (FIgure 13) where our model Indicates a 610 ohm-m block extending from the surface to $4 \mathrm{~km}$ depth. This may be caused by the mountainous volcanic terrain between these stations, or may be an artifact of oversimplified two-dimensional interpretation. We suspect the former, because our Swan Lake Valley MT model (Stark et al., 1979) also requires a resistive near-surface block east of the valley.

The decreasing resistivity structure interpreted for the upper $4 \mathrm{~km}$ is probably caused by massive Quaternary basalts and andesites (In the Cascades) or tight welded dlatomaceous Yonna tuffs (elsewhere) near the surface, underlain by fine-grained siltstones and tuffs of the lower Yonna Formation at depths of $1 \mathrm{~km}$ or more. Scorfaceous zones, rubble zones and tuffs, intercalated in the Tertiary basalt unit, may also contribute to the low resistivities at depths of $4 \mathrm{~km}$ and 1 ess. In some areas, hot brine saturation also depresses resistivities.

We have already noted that the thick mid-crustal resistive blocks seen in Figure 13 are not unusual. Moreover, our Swan Lake Va1ley MT model required blocks very similar in resistivity and position. However, the geologic meaning of these resistive blocks is not clear. Very little Is known about the pre-Tertiary stratigraphy in this area; some workers have suggested that the Tertlary basalts are underlain by a Mesozic Franciscan-type assemblage consisting of diorites, metasediments, blueschists and ultramafics. Although not all of these rocks are typically resistive, extensive hydrothermal mineralization may have acted to reduce porosity, thereby increasing resistivity. 
Figure 14 shows very conductive material below $18 \mathrm{~km}$ (in the Klamath graben) and below $40 \mathrm{~km}$ (elsewhere). Stanley et al. (1977) have discussed similar deep crustal conductive zones, suggesting that these zones are unusually shallow $(<20 \mathrm{~km})$ beneath some geothermal areas. They appear to be caused by partial melting in the deep crust and upper mantle; the shallowing phenomenon probably results from upwarping of isotherms associated with intra-crustal rifting. Thus, Figure 13 implies that the deep heat source associated with the Klamath graben encompasses Swan Lake Valley and areas further east as well.

\section{EVALUATION OF EXPLORATION METHODS}

In our prevlous report (Stark et al., 1979) we evaluated the gravity, magnetic, roving dipole resistivity, electromagnetic, dc resistivity, AMT, and MT prospecting methods as they were applied to the Klamath Basin. In this report we have examined the results of remote sensing, geochemical, gravity, magnetic, roving dipole, dipole-dipole, Schlumberger, EM, and temperature gradient surveys. Our comments regarding the usefulness and applicability of some of these techniques follow.

1. Remote Sensing: We used aerial infrared photographs to detect lineaments and faults. In this case the imagery proved most useful in substantiating the presence of cross-faulting inferred from other methods.

2. Geochemistry: Available wells and springs should always be inventoried at an early stage of exploration. The reservoir temperature estimates by Sammel (1976) and Geothermex (Appendix 2, File 72-11-27) have been placed in some doubt by the new well in Klamath Falls, which is 
hotter than these estimates Indicate. This means either that the reservolir is so compartmentalized that the temperature estimates are valid only for Individual wells, or that the assumptions involved in the estimates were not valid. We found the specific conductivity measurements useful in geologic interpretation of resistivity anomalies.

3. Gravity and Magnetics: These methods are hampered by the fundamental non-uniqueness problem in inverting potential field data, particularly in the volcanic terrane of the Klamath Basin where magnetizations and densities can be so variable. In conjunction with other information, however, the data can be extremely useful for tracing faults and for estimating depth to basement. In this area, direct associations of gravity and/or magnetic anomalies with geothermal resources are not valid, because structural and lithologic changes can account for more variation than geothermal processes such as mass transport and elevated Curfe point isotherms.

4. Roving Dipole Resistivity: This is a useful reconnalssance tool, but the data are difficult to interpret quantitatively unless supplemented by data from other resistivity methods. The Whiteline Reservoir survey did include Schlumberger and EM soundings for control, but in retrospect these soundings might have been more effective if made at a later time to define targets outlined by the roving dipole survey. Similarly, the west shore roving dipole survey should have been completed and analyzed before the dipole-dipole and Schlumberger work began there. Computer modeling can help pinpoint the sources of the often-deceptive roving dipole anomalies.

5. Schlumberger and Dipole-Dipole Reststivity: Schulumberger and dipole-dipole soundings can offer detailed, quantitative earth resistivity Information if the surveys are properly implemented. If possible, Ines 
should be laid out perpendicular to geologic strike, so that threedimensional effects are minimized and two-dimensional effects can be separated from changes with depth. We found that collinear, overlapping Schlumberger and dipole-dipole soundings were necessary to allow a wellconstrained interpretation. Finally, jolnt computer modeling of the data sets should be undertaken. When these conditions are satisfied, a quantitative subsurface resistivity picture emerges which can be valuable in selecting a drill target.

6. Time Domain EM: This technique suffers from difficulty in interpretation. We certainly applaud efforts to develop and deploy field equipment to make these measurements, but at this time most interpreters are limited to very simple models. If more powerful methods of analysis can be developed, the technique could become quite useful.

7. Temperature Gradient Surveys. These seemed to be only marginally useful for exploration, because shallow, cold groundwater flow distorts the thermal gradient.

\section{General Observations}

When overlapping information is avallable, it is imperative to make interpretations based on several sets of data. For example, in the Spence Mountain area, simultaneous modeling of dipole-dipole and Schlumberger data sets led to a clearer understanding of the subsurface than was possible with either technique alone. The same scheme was used successfully in the pulp mill area. Another example was our use of wellwater electrical conductivity measurements to aid in interpreting resistivity models. 


\section{CONCLUSIONS}

In this project, we have examined the results of most types of geothermal exploration surveys in common use, with the notable exceptions of the self potential and active selsmic methods. We have reinterpreted synthesized these data, focusing on various target areas and attempting to develop a clearer understanding of the system. Our conclusions are enumerated below:

1. The Klamath graben has been offset along northeast-trending cross faults which are inferred from geologic, remote sensing, gravity, aeromagnetic, and resistivity survey data. The shallow hydrothermal circulation is related to these faults and their intersections with north-west-trending normal faults.

2. Geochemical data indicate a reservolr temperature of about $120^{\circ} \mathrm{C}$, but certain inconsistencies in the chemical geothermometry results might be explained by a hypothetical deep steam reservoir (Sammel, 1976). The $120^{\circ} \mathrm{C}$ estimates have been placed in some doubt by the recent drilling of a $145^{\circ} \mathrm{C}$ hole in Klamath Falls.

3. Analysis of specific conductivities of well and spring water shows that hotter waters are more conductive in the Klamath Falls and 01ene Gap areas. In the Nuss Lake/Stukel Mountain areas, the hotter waters appear to be less conductive than the cooler waters, although the trend is poorly defined. This might be partially explained by the high TDS content of the local groundwater, due to long residence time in a marshy environment.

4. The resistivity data suggest that the entire area west of Upper Klamath Lake (Including the Spence Mountain, Aspen Lake, Round Lake, Long Lake, and Weyerhaeuser mill areas) is underlain by extensive conductive (25 ohm-m or less) formations at depths ranging from 1200 to $10,000 \mathrm{ft}$ 
(Fig. 12). Our two-dimensional computer models indicate that the conductive units are found at shallower depths beneath the valleys. We assume that these anomalous conductors represent clays or altered tuffs, possibly saturated with geothermal waters.

5. In the Spence Mountain drill site area, our two-dimensional computer model, based on dc resistivity data (F1g. 17), suggests conductive formations below $3000 \mathrm{ft}$. This agrees with the information from the 2000-ft drillhole; the hole penetrates volcanic material saturated with cold fresh water.

6. In the Round Lake, Long Lake, and lumber mill areas north of the Klamath River (F1g. 16), the conductive bodies are Indicated at depths as shallow as $1200 \mathrm{ft}$ in our models (Figs. 2la and 23a). Again, the conductive units appear to exist at shallower depths beneath the valleys.

7. East of Upper Klamath Lake (Fig. 6), dc resistivity and timedomain electromagnetic data suggest conductive formations at depth. The data are not very definitive, but interesting roving dipole anomalies are found in Plum Valley and near Meadow Lake Valley (Fig. 26).

\section{General Observations}

We have attempted to extract all the information possible from the data we received. It has been a time-consuming process, but we feel that we have gained a clearer understanding of the geothermal system.

The deeper plumbing system is still poorly understood. It is not known whether the three hottest areas in Klamath Falls, Olene Gap, and the Rlamath Hills are supplied by the same source, or whether they result from separate circulation patterns along the faults. Similarly, the 
nature of the heat source remains unknown. Although there is no direct evidence for an igneous heat source, the basin is ringed on three sides by Quaternary volcanics - Crater Lake, the High Cascades, and Medicine Lake Highlands. It is possible to Imagine discrete apophyses of cooling igneous bodies concealed beneath the basin. Equally plausible would be a Basin-and-Range type system, with deep circulation along fault zones penetrating a hotter-than-average crust.

A seismic velocity and attenuation study might detect evidence for a buried igneous body. Interference testing for communication between hot wells in the three RGRAs could help determine whether all the hot water emanates from a common source.

Only deep drilling can answer the fundamental questions about the nature of the resource. One purpose of this project has been to guide exploration planners. To this end we have pointed out several areas where additonal geophysical work and drilling might be warranted. These Include Meadow Lake Valley, Nuss Lake, and the sawmill and quarry area. Drilling should be planned to intercept fault zones in these areas at depth. Many geophysical anomalies have not been tested, and several enticing sites remain to be drilled. 


\section{ACKNOWLEDGEMENTS}

In our previous report (Stark et al., 1979) we expressed our gratitude to RIchard G. Bowen and Joseph Riccio of the Oregon Department of Geology and Mineral Industries, the staff at the Geo-Heat Utilization Center at Oregon Institute of Technology, Ed Sammel of the U.S. Geological Survey, Reeva Vozoff, on leave from Macquarle University, and the representatives of companies and institutions who contributed their data and ideas to the study. We wish to thank these individuals once again.

The regional magnetotelluric data reported here were collected and analyzed by Wolfgang Goubau, Robert Miracky and Thomas Gamble. To these LBL physicists we extend our thanks.

We appreciate the efforts of Deborah Hopkins of Lawrence Berkeley Laboratory in preparing the statistical analysis of the specific conductivity data, and the help of Colin Goranson, also of Lawrence Berkeley Laboratory, who shared his knowledge of the geology and geothermal resources in the City of Klamath Falls.

We also thank Margot Harding, Eric Cheney, Ellen Diamond, and the staff of the Technical Information Department at Lawrence Berkeley Laboratory.

This study was supported through the State-Coupled Program of the Division of Geothermal Energy, Resource Applications Branch of the U.S. Department of Energy under Contract No. W-7405-ENG-48. 


\section{REFERENCES CITED}

Brace, W. F., 1971, Resistivity of saturated crustal roccks to $40 \mathrm{~km}$ based on laboratory measurements: Geoph. Monogr. 14, ed. by

J. R. Heacock, p. 243-255.

Cantwe11, T., and Orange, A., 1965, Further deep resistivity measurements in the Pacific Northwest: Jour. Geoph. Res., v. 70, no. 16, p. 4068-4072.

Dey, A., 1976, Resistivity modeling for arbitrarily shaped two dimenslonal structures: Berkeley, Lawrence Berkeley Laboratory, report, LBL-5283.

Dey, A., and Morrison, H. F., 1977, An analysis of the bipole-dipole method for geothermal exploration: Berkeley, Lawrence Berkeley Laboratory, report, LBL-6332.

EROS, 1979, 1:125,000 aerial Infrared photographs: Sioux Fa1ls, South Dakota, Earth Resources Observation System Data Center.

Jupp, D. L. B., and Vozoff, 1977, Two-dimensional magnetotelluric Inversion: Geoph. Jour. Royal Astron. Soc., v. 50, no. 2, p. $333-352$.

Keller, G. V., and Frischknecht, F. C., 1966, Electrical methods in geophysical prospecting: Oxford, Pergamon Press, p. 19.

Leonard, A. R., and Harris, A. B., 1974, Groundwater in selected areas in the Klamath Basin, Oregon: Oregon State Engineer Groundwater Report No. 21 . 
Keller, G. V., and Frischknecht, F. C., 1966, Electrical methods in geophysical prospecting: Oxford, Pergamon Press, p. 19.

Leonard, A. R., and Harris, A. B., 1974, Groundwater In selected areas In the Klamath Basin, Oregon: Oregon State Engineer Groundwater Report No. 21.

Lund, J. W., Culver, G. G., Doyle, S., Leinau, P. J., Rathmacher, A., and Svanevik, L. S., 1978, Geothermal hydrology and geochemistry of Klamath Falls, Oregon, urban area: Klamath Falls, Geo-Heat Utilization Center, Oregon Institute of Technology.

Newcomb, R. C., 1958, Yonna formation of the Klamath River basin, Oregon: Northwest Sclence, v. 32, no. 2, p. 41-48.

Peterson, N. V., and McIntyre, J. R., 1970, The reconnaissance geology and mineral resources of eastern Klamath County and western Lake County, Oregon: Oregon Department of Geology and Mineral Industries Bulletin 66.

Samme1, E. A., 1976, Hydrologic reconnalssance of the geothermal area near Klamath Fa1ls, Oregon: U.S. Geological Survey Open File Report WRI 76-127.

Stanley, W. D., Boehl, J. E., Bostick, F. X., and Smith, H. W., 1977, Geothermal significance of magnetotelluric sounding in the eastern Snake-RIver Plain-Yellowstone reglon: Journal Geophy. Res., v. 82, no. 17 , p. 2501-2514.

Stark, M., Goldstein, N., Wollenberg, H., Strisower, B., Hege, M., and Wilt, M., 1979, Geothermal exploration assessment and interpretation, Klamath Basin, Oregon - Swan Lake and Klamath Hills area:

Thermal Power Company, 1978, Temperature gradient logging in the Klamath Hills area, Rlamath County, Oregon: San Francisco, Natomas Company. 
U.S. Geological Survey, 1973a, Aeromagnet1c map of the Klamath Falls and part of the Crescent $1^{\circ}$ by $2^{\circ}$ Quadrangle, Oregon: U.S. Geological Survey Open-file map 72-392. 1973b, Aeromagnet1c map of the Medford sheet, Oregon: U.S. Geological Survey Open-file map 72-392.

Vacquier, V., Steenland, N. C., Henderson, R. G.; and Zietz, I., 1963, Interpretation of aeromagnetic maps: Boulder, Geological Society of America, Memoir 47.

Van Deusen, J. E., III, 1978, Mapping geothermal anomalles in the Klamath Falls, Oregon, reglon using gravity and magnetic data (MS thesis): University of Oregon, Department of Geology.

Zohdy, A. A. R., 1974, Use of Dar-Zarouk curves in the Interpretation of vertical electrical sounding data: U.S. Geological Survey Bulletin 1313-D. 


\section{APPENDIX 1}

KIAMATH BASIN GEOTHERMAL RESOURCE BIBLIOGRPAEY

Arnold, D., 1977, Energy crials; Opportunity for savings at Presbyterian Intercomunity Hospital: Geo-Heat Utilization Center Quarterly Bulletin, v.2, no.4, Pp. 1-3.

Berg, J.W., Jr., and Baker, C.D., 1963, Oregon earthquates, 1841 through 1958: Seismological Society of America Bulletin, v.53, no.1, Pp. 95-108.

Blackwell, D.D., and Chapman, D.S., 1977, Interpretation of geothermal gradient and heat flow data for basin and range geothermal systems: Geothermal Resources Counc1l, May 9, 1977, pp. 19-20.

Blank, H.R., 1966, General features of the Bouguer gravity field in southwest Oregon: U.S. Geological Survey Professional Paper 550-c, pp. 113-119.

Blank, H.R., 1966, Aeromagnetic and gravity surveys of the Crater Lake Region, Oregon: In H.M. Dole (Ed.), Andesite Conference Guidebook, pp. 42-52.

Bodvarsson, G., 1966, Energy and power of geothermal resources: Oregon Dept. of Geol. and Min. Indust., v.28, no.7, Pp. 117-124.

Bodvarsson, G., Couch, R.W., MacFarlane, W.T., Tang, R.W., and Whitsett, R.M., 1974. Telluric exploration for geothermal anomalies in Oregon: The Ore Bin, v.36, no.6, pp. 93-107.

Bowen, R.G., 1968, Geochemical sampling data, Klamath and Lake Counties, Oregon: Oregon Dept. of Geol. and Min. Indust., Open File Report, unpublished.

Bowen, R.G.. 1972, Geothermal overviews of the western United States: California Geothermal Resources Council, pp. 138-146.

Bowen, R.G., 1975, Geothermal energy: Oregon Dept. Geol. and Mineral Indust. Misc. Paper 18, Pp. 43-50.

Bowen, R.G., 1975b, Geothermal gradient data: Oregon Dept. of Geol. and Mineral Indust. Open File Report 0-75-3, 133 pp.

Bowen, R.G., Blackwell, H. D., and Hull, D.A., 1975, Geothermal studies and exploration in Oregon: Oregon Dept. of Geol. and Mineral Indust., Open File Report 0-75-7, 65 pp. 
Bowen, R.G., and Peterson, N.V., 1970, Thermal springs and wells in Oregon: Oregon Dept. Geol. and Mineral Indust. Misc. Paper 14.

Cantwell, T., Nelson, P., Webb, J., and Orange, A.S., 1965, Further deep resistivity measurements in the Pacific Northwest: Jour. Geoph.Res.. v.70, pp. 4068-4072.

Couch, R.W., and Lowell, R.P. 1971, Earthquakes and seismic energy release in Oregon: The Ore Bin, v.33, no.4, Pp.61-84.

Culver, G., 1975, A case for the down hole exchanger: Geo-Heat Utilization Center quarterly Bulletin, v.1, no.2.

Culver, G., 1976, DHE investigations: Geo-Heat Utilization Quarterly Bulletin, v.2, no.2, pp. 1-2.

Culver, G., 1976b, Presbyterian Intercomunity Hospital goes geothermal: Geo-Heat Utilization Center Quarterly Bulletin, v.1, no.3.

Culver, G.G., 1977, Well drilling for < 250' F water: Geo-Heat Utilization Center Quarterly Bulletin, v.3, no.1, Pp. 8-10.

Culver, G.G., Lund, J.W., and Svanevik, L.S., 1974, Klamath Falls hot water well study: Oregon Institute of Technology, Klamath Falls, Dregon (UCRL-13614), $61 \mathrm{pp}$.

Dey, A. and Morrison, H.F., 1977, An analysis of the bipole-dipole resistivity method for geothermal exploration: Lawrence Berkeley Laboratory Report, LBL-6332.

Dicken, S.N., 1950. Oregon geography: Edwards Bros.. Ann Arbor, Michigan, 1st ed., 104 pp., pp. 61-67.

Dole, H.M., 1967, Geology is-for everyone--fifteenth blennial report of the state geologist, 1964-1966: Oregon Dept. Geol. and Mineral Indust. Bull. $59,27 \mathrm{pp}$.

Fournier, R.O., 1973, An empirical Na-K-Ca geothermometer for natural waters: Geochim. Cosmochim. Acta, v.37, pp. 1255-1275.

Frank, F.J., and Harris, A.B., 1969, water resources appralsal of Crater Lake National Park, Oregon: U.S. Geological Survey Open File Report, 26 pp.

Geomonics, 1977, A telluric-magnetotelluric survey of the Swan Lake Valley Area, Oregon: Geonomics Inc., Berkeley, California, Project No. 164, prepared for Creslenn Oil Co., Oklahoma City, Oklahoma.

Geothermal Energy, 1974, Heat mine spurs big Oregon push (Xlamath Falls): Geothermal Energy, v.2, no.10, pp. 32-33. 
Groh, E.A., 1966, Geothermal energy potential in Oregon: The ore Bin, v. 28, no.7, pp. 125-135.

Group Seven, 1972, Electrical resistivity surveys at Klamath Falls and Honey Lake: Group Seven, Inc., Golden Colo., Final report prepared for Gulf Mineral Resources Co., Denver, Colo., 153 p.

Hubbard, L.L., 1970, Water budget of-Upper Klamath Lake, Southwestern Oregon: U.S. Geol. Survey Hydrologic Investigations Atlas HA-351.

Hull, D.A., Blackwell, D.D., Bowen, R.G., Peterson, N.V., and Black, G.L., 1977, Geothermal gradient data: Oregon Dept. Geol. and Mineral Indust., Open File Report 0-77-2, 135 Pp.

Hull, D.A., and Newton, V.C., Jr., 1976, Geothermal activity in 1975: The ore Bin, v.38, no.1, pp. 10-17.

Hunt Energy Corporation, 1978, Well permits issued: Hunt Energy Corporation (Well permits issue to Hunt Energy Corporation to June 1978, map with three pages).

Illian, J.R., 1970, Interim report on the ground water in the Klamath Basin, Oregon: Oregon State Engineer, $110 \mathrm{pp}$.

Johnson, D.W., 1918, Block faulting in the Klamath Lakes Region, Oregon: Jour.Geol., v.26, pp. 229-236.

Johnson, L., Jr., 1969, Obsidian hydration rate for the Klamath Basin of California and Oregon: Science, v.165, no.3900, pp. 1354-1346, illus.

Karr, D.J., 1977, Geothermal energy and water resources: Oregon State University Water Resources Research Institute, Corvallis, Oregon, $121 \mathrm{pp}$.

Karr, D.J., and Laskin, S., 1977, The geothermally heated greenhouse: Geo-Heat Utilization Center Quarterly Bulletin, v.2, no.3, pp. 1-3.

Kibby, H.V., Donaldson, J.R., and Bond, C.E., 1968, Temperature and current observations in Crater Lake, Oregon: Limnol. Oceanog., v.13, no.2, pp. 363-366.

Klamath Ranger District, 1971, Klamath Ranger district map. Winema National Forest, Oregon: Willamette Meridian, U.S. Dept. Agricult. Forest Service.

Lawrence, R.D., 1974. Northern termination of the basin and range province in Oregon: Oreg. Acad. Sci., Proceedings, v.10, Pp.68-69. 
Lawrence, R.D., 1976, strike-slip faulting terminates the basin and range province in Oregon: Geol. Soc. Amer. Bull.., v.87, no.6, pp. 846-850.

Leonard, A.R., and Harris, A.B., 1974, Ground water in selected areas in the Klamath Basin, Oregon: Oregon State Engineer, Ground Water Report No. 21, 104 Pp.

Lienau, P.J., 1975, OIT adds a new building to its geothermal heating system: Geo-heat Utilization Center Quarterly Bulletin, v.1, no.2, pp. 1-2.

Lienau, P., 1976, Report on center activities: Geo-Heat Utilization Center Quarterly Bulletin, v.2, no.1, pp. 8-9.

Lienau, P.J., 1976b, A comparison of downhole vs. surface heat exchangers for geothermal heating of schools: Geo-Heat Utilization Center Quarterly Bulletin, pp. 5-6.

Lienau, R.J., 1976c, Geo-heated swimming pool: Geo-Heat Utilization Center Quarterly Bulletin, v.1, no.4, pp. 2-3.

Lienau, P.J., 1977, Geothermal heating system, Oregon Institute of Technology: Geo-Heat Utilization Center Quarterly Bulletin, v.2, no.4, pp. 6-8.

Ilenau, P.J., n.d., Agribusiness geothermal energy utilization potential of Klamath and Snake River basins, Oregon: Manuscript, pp. 1-10.

Lienan, P.J., and Lund, J.W., n.d., Utilization and economics of geothermal space heating in klamath Falls, Oregon: Manuscript, pp. $1-10$.

Lienau, P.J., Lund, J.W., and Culver, G.G., 1976, Klamath County geo-heating districts: Oregon Institute of Technology, Klamath Falls, Oregon.

Lund, J.W., 1975, Geology and energy utilization of the Klamath Falls known geothermal resource area: Proceedings, 13th Annual Symposium on Engineering Geology and Solls Engineering, Hoscow, Iaaho.

Lund, J.W., 1975b, New development in the Klamath Falls KGRA: Geo-Heat Utilization Center Newsletter, v.1, no.1, p. 3.

Lund, J.W., 1976, Geothermal de-icing of a highway pavement: Geo-Heat Utilization Center quarterly Bulletin, v.1, no.3, pp. 7-9.

Lund, J.W., 1976, Geothermal de-icing of pavements: Geo-Heat Utilization Center Quarterly Bulletin, v.1, no.4, p. 7. 
Lund, J.W., 1977, Direct use of geothermal water for apartment heating: Geo-Heat Utilization Center quarterly Bulletin, v.2, no.3, pp. 7-8.

Lund, J.W., 1977b. Geothermal heating of Kingswood Apartments, Klamath Falls: Geo-Heat Utilization Center guarterly Bulletin, v.3, no.1, Pp. 4-6.

Lund, J.W., 1978. Big springs: Geo-Heat Utilization Center Quarterly Bulletin, v.3, no.3, pp. 7-13.

Lund, J.W., n.d., Geology and energy utilization of the Klamath Falls known geothermal resource area: Manuscript, Pp. 187-200.

Lund, J.W., Culver, G., and Lienau, P.J., n.d., Groundwater characteristics and corrosion problems associated with the use of geothermal water in Klamath Falls, Oregon: Manuscript, $17 \mathrm{p}$.

Lund, J.W., Culver, G.G., and Svanevik, L.S., 1974, Utilization of geothermal energy in Klamath Falls: Proceedings, Conference on Geothermal Energy for Industrial, Agricultural and Commercial Uses, Oregon Institute of Technology, Klamath Falls, Oregon, pp. 146-178.

Lund, J.W., Culver, G.G., and Svanevik, L.S., 1976, Utilization of intermediate-temperature geothermal water in Klamath Falls, Oregon: Proceedings of the Second United Nations Symposium on the Development and Use of Geothermal Resources, San Francisco, California, 20 May 1975, v.3, pp. 2147-2154.

Lund, J.W.., and Lienau, P.J. 1976, Mini-heating district for Klamath Falls churches: Geo-Heat Utilization Center Quarterly Bulletin, v.1, no.4.

Lyons, T., 1976, Geothermal energy in California--status report. Appendix B, Administrative requirements for development of geothermal resources: Jet Propulsion Laboratory, Pasadena, California, JPL-5040-25 (Rev. A), Pp. B.1-B.11.

MacLeod, N.S., Walker, G.W., and McKee, E.H., 1975, Geothermal significance of eastward increase in age of Opper Cenozoic rhyolitic domes in southeastern Oregon: U.S. Geol. Survey Open File Report 75-348, 22 p. 
Mariner, R.H., Presser, T.S., Rapp, J.B., and willey, L.M., 1975, The minor and trace elements, gas and isotope composition of principal hot springs of Nevada and Oregon: U.S. Geol. Survey Open File Report 75-348, 27 p.

Mariner, R.H., Rapp, J.R., Willey, L.M., and Presser, T.S., 1974, The chemical composition and estimated minimum reservoir temperatures of selected hot springs in oregon: USGS Open File Report, 27 p.

Maynard, L.C., 1974, Geology of Mount McLoughlin: University of Oregon, Unpublished thesis, $139 \mathrm{p}$.

Merewether, E.A., 1953, Geology of the lower Sprague River area, Klamath County, Oregon: Master's thesis, Oregon State University, $62 \mathrm{p}$.

Meyers, J.D., and Newcomb, R.C. 1952, Geology and ground water resources of the Swan Lake-Yonna Valley area, Klamath County, Oregon: U.S. Geol. Survey Open File Report, $151 \mathrm{p}$.

Nathenson, M., and Muffler, L.J.P., 1975, Geothermal resources in hydrothermal convenction systems and conduction-dominated areas: In D.E. White and D.I. Williams (Eds.), Assessment of geothermal resources of the United States, 1975, U.S. Geol. Survey Circular 726, pp. 104-121.

Natomas, 1978, 1) Memorandum, 26 February 1976, 2) Map, 3) Nell logs; 4) Seismicity report on the Klamath Hills prospect, Klamath County, Oregon: Microgeophysics Corp., Golden, Colo.. 22 Dec. 1975; 5) Klamath Hills geothermal rpospect, Klamath County, Oregon: Thermal Power Company, San Francisco, Calif., 7 June 1976; 6) Temperature gradient logging in the Klamath Hills area, Klamath County, Oregon: A.B. Esmilla Geothermal Surveys, Los Angeles, Calif., October 1975: Natomas Company, San Francisco, Calif.

Newcomb, J.M., 1976, Maintenance problems and solutions in geothermal well plumbing: Geo-Heat Utilization Center Quarterly Bulletin, v. I, no.4, pp. 4-6.

Newcomb, R.C., 1958, Yonna formation of the Klamath River Basin, Oregon: Northwest Science, v.32, no.2, Pp. 41-48.

Newcomb, R.C., and Hart, D.H., 1958, Preliminary report on the groundwater resources of the Klamath River Basin, Oregon: U.S. Geol. Survey, Open File Report, 248 p.

Newton, V.C., 1971, Folsom Basin disposal site, Klamath County, Oregon: oregon Dept. Geol. and Mineral Indust., 10 p. 
Newton, V.C., Jr., and Peterson, N.V., 1973, Geologic criteria for siting nuclear power plants in Oregon: Oregon Dept. Geol. and Mineral Industr., $65 \mathrm{p}$.

Oregon State Water Resources Board, 1971, Klamath Basin: Oregon State Water Resources Baord, Salem, Oregon, 288 p.

Pacific Southwest Inter-Agency Committee, Sacramento, Water Management Technical Subcommittee, 1973, River Mile Index--Klamath River, Pacific slope Basin, California-Oregon, 56 p.

Peterson, D.L., and Meyer, R.F., 1976, Principal facts for a gravity survey of Sumer Lake known geothermal resource area, Oregon: U.S. Geol. Survey OFR-76-702A, 5 PP.

Peterson, N.V., 1959, Lake County's new continuous geyser: The Ore Bin, v.21, no.9, pp. 83-88.

Peterson, N.V., and Groh, E.A., 1967, Geothermal potential of the Klamath Falls area, Oregon--a preliminary study: The Ore Bin, v.29, no.11, pp. 209-231.

Peterson, N.V., and McIntyre, J.R., 1970, The reconnaissance geology and mineral resources of eastern Klamath County and western Lake County, Oregon: Oregon Dept. of Geol. and Mineral Indust. Bulletin $66,70 \mathrm{pp}$.

Phillips, K.N., Van Denburgh, A.S., 1968, Hydrology of Crater, East, and Davis Lakes, Oregon: U.S. Geol. Survey Water Supply Paper 1859-E, Pp. 1-60.

Purvine, w.D., 1974, Utilization of thermal energy at Oregon Institute of Technology, Klamath Falls, Oregon: Proceedings, International Conference on Geothermal Energy; Oregon Institute of Technology, Klamath Falls, Oregon.

Renner, J.L., 1976, Selected geothermal resources data--hydrothermal convection systems in the states of Alaska, Arizona, California, Colorado, Hawaii, Idaho, Montana, Nevada, New Mexico, Oregon, Utah, Washington, and Wyoming: U.S. Geol. Survey $C D-76-001$, 357 pp.

Renner, J.L., White, D.E., and Williams, D.L., 1975, Hydrothermal convenction systems. In D.E. White and D.L. Williams (Eds.), Assessment of geothermal resources in the United States--1975, U.S. Geol. Survey Circular 726, pp. 5-57.

Rineheart, J.S... 1970, Geysering action in drilled well, Crump, Lake County, Oregon: J.Geophys. Res., v.75, no.32, PP. 6714-6716, illus. 
Sacarto, D.M., 1976, State policies for geothermal development: National Science Foundation, Washington, D.C., 24 pp.

Samel, D.A., 1976, Hydrologic reconnaissance of the geothermal area near Klamath Falls, Oregon: U.S. Geol. Survey Open File Report WRI 76-127, $129 \mathrm{pp}$.

Sass, J.H.. and Sammel, E.A., 1976, Heat-flow data and their relation to observed geothermal phenomena near Klamath Falls, Oregon: J. Geophys. Research, v.81, no.26, pp. 4863-4868.

Scintrex Mineral Surveys, Inc., 1972, Aeromagnetic map of the Klamath Falls and Cresent Sheets, Oregon: U.S. Geol. Survey Open File Report.

Senterfit, R.M., and Bedinger, G.M., 1976, Audio-magnetotelluric data log and station location map for Klamath Falls known geothermal resource area, Oregon:. U.S. Geol. Survey Open File Report 76-320, pp. 1-6.

Smith, J.L.. Isselhardt, C.F., and Matlick, J.S., 1977, Summary of 1976 geothermal drilling--Kestern United States: Geothermal Energy Magazine, v.5, no.5, Pp. 8-9, 11-13, 15-17.

Storey, D.M.. 1974, Geothermal drilling in Klamath Falls, Oregon: Proceedings, International Conference on Geothermal Energy. Oregon Institute of Technology, Klamath Falls, Oregon, 8 October 1974, $10 \mathrm{pp}$.

Tang, R.W.Y.. 1974, Geothermal exploration by telluric currents in the Klamath Falls area, Oregon' Master's thesis, Oregon State University, Corvallis, Oregon, $86 \mathrm{pp}$.

Thiruvathukal, J.V., Berg, J.W., Jr., and Heinrichs, D.C., 1970, Regional gravity of Oregon: Geol. Soc. Amer. Bull., v.81, pp. 725738.

Trauger, F.D., 1950, Basic groundwater data in Lake County, Oregon: U.S. Geol. Survey Prof. Paper 492, p. 271.

U.S. Geological Survey, 1972, Surface water supply of the United States, 1966-1970. Part II. Pacific slope basins in California. Volume 2. Basins from Arroyo Grande to Oregon state line except central valley: U.S. Geological Survey Water Supply PaPer 2129, pp. 526-659.

U.S. Geological Survey, 1977, Water resources investigations in Oregon, 1977: U.S. Geological Survey Water Data Report OR-77-1, 607 Pp. 
van Deusen, J.E., 1978, Mapping geothermal anomalies in the Klamath Falls, oregon reglon using gravity and aeromagentic data: us thesis, University of Oregon, Eugene, pp.

van Meter, C., 1940, Heating with hot water wells: Driller, v.14; no.4, pp. 4-7.

van Orstrand, C.E.. 1938, Temperatures in the lava beds of east-central and south-central Oregon: Amer. J. Sci., v.35, no.205, pp. 22-46.

von Hake, C.A., 1976, Earthquake history of oregon: Earthquake Information Bulletin, v.8, no.3, pp. 30-33, illus.

Walker, G.W., 1963, Reconnaissance geologic map of the eastern half of the Klamath Falls (AMS) quadrangle, Lake and Klamath Counties, Oregon: U.S. Geol. Survey Mineral Investigations Field Studies Map, MF-260.

Walker, G.W., 1970, Cenozoic ash flow tuffs of Oregon: The Ore Bin, v.32, no.6, pp. 97-115.

Walker, G.W., 1973, Preliminary geologic and tectonic maps of oregon east of the l2lst meridian: U.S. Geol. Survey Misc. Field Studies Map MF-495.

Walker, G.W., 1974. Some implications of late Cenozoic volcanism to geothermal potential in the high lava plains of south-central Oregon: The ore Bin, v.36, Pp. 109-119.

Walker, G.W., Delrymple, G.B., and Lanphere, M.A. 1974. Index to potassium argon ages of Cenpzoic volcanic rocks of Oregon: U.S. Geol. Survey, Misc. Field Studies Map MF-569.

Walker, G.W., and King, P.B., 1969, Geologic map of Oregon: U.S. Geol. Suevey Misc. Geol. Map I-595.

Walker, G.W., MacLeod, N.S., and McKee, E.H., 1974, Transgressive age of late Cenozoic silicic volcanic rocks across southeastern Oregon-impoications for geothermal potential: Geol. Soc. Amer. Abs. with Programs, v.6, no.3, p. 272.

Wells, F.G., and Peck, D.L., 1961, Geologic map of Oregon west of the 12lst meridian: U.S. Geol. Survey Misc. Geol. Inv. Map 1-325.

Wells, R.E.. 1975, Geology of the Drake Peak rhyolite complex and the surrounding area, Lake County, Oregon: Master's thesis.

Weyerhauser, n.d., Material received from Geothermex on geothermal exploration work for Wyerrhauser Co. and Pacific Power and Light co. 
Wimer, R.D., Lamori, P.N., and Grant, A.D., 1977, Potential environmental issues related to geothermal power generation in Oregon: The Ore Bin, v.39, no.5, pp. 73-91.

Youngquist,.., 1977 . Pacific northwest geothermal--1976 review, 1977 outlook: Geothermal Energy Magazine, v.5, no.6, pp. 8-13, 15-17.

Zoback, M.L., and Thompson, G.A., 1976, Evidence of left-lateral slip on basin and range fault: Geol. Soc. Amer.. Abstr. Programs, v.8, no.6, p. 1182 . 
APPENDIX 2

MATERIAL RECEIVED FROM GEOTHERMEX

ON GEOTHERMAL EXPLORATION WORK FOR

WEYERHAEUSER COMPANY AND PACIFIC POWER AND LIGHT COMPANY

Report, "Reconnaissance Evaluation of Geothermal Resources, Weyerhaeuser Company Lands, South-Central Oregon," James B. Koenig, December 1, 1971.

File 72-11-27, containing:

Report, "Geology and Conditions Relating to Geothermal Prospecting in the Quartz Mountain area, South-Central Oregon (Area 2)," J. R. McIntyre.

Report, "Geochemical Interpretation of Spring and Well Waters, Southcentral Oregon and Adjacent California," James B. Koenig and Murray C. Gardner.

\section{File 74-3-9, containing:}

Final Report on Geothermal Exploration of the Klamath Basin Area, Oregon, 1973-1974, March 9, 1974.

Bouguer Gravity Map of the Klamath Falls Area, Klamath and Jackson Counties, Oregon; Siskyou County, J. VanDeusen and H. R. Blank, 9 February 1974.

Bouguer Gravity Map of Oregon and California Klamath Falls and Vicinity.

Laboratory Report - Gross Chemlstry of Water Samples.

Aeromagnetic Map of the Klamath Falls and Part of the Crescent $1^{\circ}$ by $2^{\circ}$ Quadrangles, Oregon, 1972.

Geology of the Browns Mountain, Mt. McLaughlin Area, Southern Oregon Cascades, with Map Attachment.

Report, Supplementary Report Number One, Bouguer Gravity and Total Magnet1c Intensity Maps of the Klamath Falls Area, Klamath and Jackson Counties, Oregon; Siskyou County, California, 7 November 1974, J. VanDeusen and $B$. Richard Blank.

File 75-2-14, containing:

Final Report on Geothermal Exploration of the Klamath Basin Area, Oregon, 1974-1975, by GeothermEx, Inc., February 14, 1975.

F1le 75-4X, containing:

Summary and Interpretation of Gravity, Aeromagnetic, and Electrical Resistivity Data in the Klamath Basin, Oregon, by GeothermEx, Inc., April 1975. 
Geology and Site Selection for an Exploratory Drill Hole in the Spence Mountain Target Area, by GeothermEx, Inc., July 1975.

Review of Geoelectrical Survey Whiteline Reservolr Area.

Geology and Geothermal Resource Evaluation of the Copco Lake Area, Cascade Range, Oregon and California, by GeothermEx, Inc., October 1975.

Geolog1c Map, Copco Lake Area.

Plate 2, Geologic Cross-Sections of Copco Lake-Cascade Range Area, OregonCalifornia.

Final Report on Geothermal Exploration of the Klamath Basin Area, Oregon, 1975-1976, by GeothermEx, Inc., March 25, 1976.

Report from LFE Environmental Analysis Laboratorles to GeothermEx, dated May 25, 1976.

Addendum to Final Report, Geothermal Exploration of the Rlamath Basin Area, Oregon, 1975-1976, by GeothermEx, Inc., July 2, 1976.

\section{File 76-X-X-4, containing:}

Just1ce Core Drilling Company, Driller's Reports dated as follows:

December 19, 1975, February 7, 1976 March 20, 1976 Apr11 30, 1976

December 22, 1975 February 15, 1976 March 27, 1976 May 8, 1976

December 31, 1975 February 21, 1976 March 31, 1976 May 8, 1976

January 10, 1976 February 29, 1976 April 7, 1976

January 17, 1976 March 6, 1976 Apr11 17, 1976

January 31, 1976 March 13, $1976 \quad$ Apri1 24, 1976

File $76-X-X-3$, containing:

Large Graph, Doak Mountain - Resistance and S.P. - comp1led by FTI.

Weyerhaeuser/Pacific Power and Light No. 1 Dally Drilling Log, Master Copy.

Weyerhaeuser/Pacific Power and Light No. 1 Lithologic and Core History Logs, Master Copy.

Analysis and Evaluation of Electrical Resistivity Investigations in the Vicinity of Klamath Falls, Oregon by Harding-Lawson Assoclates, by R. B. Furgerson, August 4, 1974.

Electrical Geophysical Investigations of the Whiteline Reservolr Area, Oregon, by R. B. Furgerson, September 1975. 
Report published by GeothermEx, Including Conclusions, Recommendations, Budget, Summary of Program Activities.

Electrical Resistivity Investigations in the Vicinity of Klamath Falls, Oregon, by W. E. Black and J. S. Nelson, Harding-Lawson Asosclates, February 12, 1974.

Burgundy colored box, containing:

Reslstivity Survey near Rlamath Falls (Oregon) by Geoterrex LTD, October-November 1974. 
This report was done with support from the Department of Energy. Any conclusions or opinions expressed in this report represent solely those of the author(s) and not necessarily those of The Regents of the University of California, the Lawrence Berkeley Laboratory or the Department of Energy.

Reference to a company or product name does not imply approval or recommendation of the product by the University of California or the U.S. Department of Energy to the exclusion of others that may be suitable. 


$$
\text { 1) m m }
$$

TECHNICAL INFORMATION DEPARTMENT LAWRENCE BERKELEY LABORATORY UNIVERSITY OF CALIFORNIA BERKELEY, CALIFORNIA 94720 a

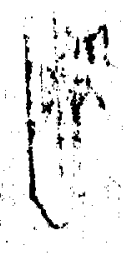

